\title{
WELLBORE BREAKOUT ANALYSIS FOR DETERMINING TECTONIC STRESS ORIENTATIONS IN WASHINGTON STATE
}

\author{
by
}

Marian Magee and Mary Lou Zoback ${ }^{1}$

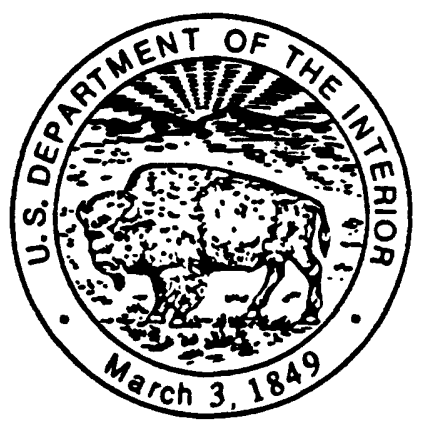

OPEN-FILE REPORT $92-715$

This report is prellminary and has not been reviewed for conformity with U.S. Geological Survey editorial standards or with the North American Stratigraphle Code.

Any uee of trade, product or firm names is for descriptive purpoess only and does not Imply endorsement by the U.S. Covernment.

\section{Menlo Park, California}

1992

1 Menlo Park, CA 


\section{Contents}

$\begin{array}{ll}\text { ABSTRACT } & 1 \\ \text { INTRODUCTION } & 1 \\ \text { METHOD } & 2 \\ \text { RESULTS } & 2 \\ \quad \text { Southwestern Coastal Washington } & 3 \\ \quad \text { Canadian Border } & 4 \\ \quad \text { Puget Sound Basin } \quad \text { Olympic Peninsula } & 4 \\ \text { DISCUSSION } & 6 \\ \text { CONCLUSIONS } & 6 \\ \text { ACKNOWLEDGEMENTS } & 8 \\ \text { REFERENCES } & 8 \\ \text { TABLE 1 Wellbore Breakout Analysis--Washington State } & 9 \\ \text { FIGURE CAPTIONS } & 12 \\ \text { FIGURES } & 13 \\ \text { APPENDIX 1 } & 14\end{array}$

Table A-1 Washington State Petroleum Wells completed in 1970 or later 21

Table A-2 Summary of Wellbore Breakout Analysis 28 APPENDIX 2

Details of log observations for wells with wellbore enlargements 31

Summary statistical analysis for wells with wellbore enlargements 38 


\begin{abstract}
This report presents the results from a detailed analysis of wellbore breakouts from petroleum exploration well logs in the state of Washington. Principal horizontal stress directions are inferred from the measured azimuths of borehole breakouts and are used to place constraints on the style of faulting and regional deformation within the state. Our results indicate mean maximum horizontal stress directions $\left(\mathrm{S}_{\mathrm{Hmax}}\right.$ ) of about $\mathrm{N} 20^{\circ} \mathrm{E}$ near the south-central Washington coast, $\mathrm{N}^{\circ}-10^{\circ} \mathrm{E}$ within the Puget Sound, and approximately NW on the Olympic peninsula. These stress data are consistent with horizontal stress directions inferred from earthquake focal mechanisms in the Puget Sound basin (Ma and others, 1991) and with directions inferred from mapped cinder cone alignments in the Cascade Range of Washington and Oregon (Magee, in prep.), but are inconsistent with geodetic data in the Puget Sound basin and the Olympic Peninsula which indicate ENE maximum horizontal strain accumulation (Savage and others, 1991). Enigmatically, the breakout orientations observed in several wells appear to be dominated by local stresses in the vicinity of actively deforming folds or faults.
\end{abstract}

\title{
INTRODUCTION
}

The state of Washington, and much of the Pacific Northwest region, is situated landward of the Cascadia subduction zone where oceanic crust of the Juan de Fuca plate is being overridden by the North American plate in a N67 $\mathrm{E}$ direction at a rate of $4 \mathrm{~cm} / \mathrm{year}$ (Riddihough, 1984; DeMets and others, 1990). Subduction of oceanic crust younger than $10 \mathrm{Ma}$ might be expected to result in strong shear coupling along the plate boundary and evidence of ENE compression directed roughly parallel to plate convergence (Molnar and Atwater, 1978). However, previous stress data in the Puget Sound region were sparse and only weakly defined a $\mathrm{N}-\mathrm{S}$ directed compressive stress regime (Zoback and Zoback, 1989).

Orientations of in-situ horizontal stresses can be inferred from oriented elliptical borehole cross-sectional enlargements which are often observed in petroleum exploration wells. Several recent studies have demonstrated that these borehole enlargements, commonly referred to as wellbore breakouts, develop parallel to the least principal horizontal stress direction in response to stress concentration around the borehole wall due to unequal horizontal stresses (Gough and Bell, 1981; Zoback and others, 1985; Hickman and others, 1985). Stress-induced wellbore breakouts can be inexpensively and straightforwardly identified through the analysis of high resolution, 4-arm caliper, noncomputed dipmeter logs routinely recorded in petroleum industry wells (Plumb and Cox, 1987).

In order to define the tectonic stress field in Washington more precisely, we attempted to acquire non-computed dipmeter logs for all 67 petroleum exploration wells drilled in the state after 1970 when the high-resolution caliper tool became widely used. Table A-1 (Appendix 1) lists specific well names, year and total depth drilled (McFarland, 1983), as well as comments concerning the availability of dipmeter logs. We were able to acquire and analyze dipmeter logs for only 22 of these 67 wells, nearly all of which were located in western Washington. Unfortunately, all offshore and most coastal wells were drilled before 1970 and dipmeter logs were either not run in them, or are from the 3-arm caliper tool and therefore inappropriate for this analysis. Petroleum companies have recently drilled a few wells in eastern Washington; researchers at Princeton University analyzed logs for two of these wells (V. Mount, 1989, written communication) but logs for the other wells in eastern Washington were not available at the time of this study. 


\section{METHOD}

The dipmeter tool consists of two orthogonal pairs of caliper arms oriented with respect to magnetic north; these caliper arms record hole diameter as well as measure electrical conductivity of the formation around the borehole through four electrode pads situated on the arms. Due to cable torque during logging the tool normally rotates as it is pulled up the hole. If the tool encounters an elongated section of the hole, two of the oriented caliper arms lock into the elongation direction and record a hole diameter larger than bit size while the other pair records the orthogonal diameter close to bit size (about 9 to 11 inches). Depending on how continuous and well developed the breakouts are, the caliper arms remain locked along a fairly constant azimuth until the borehole becomes circular again, at which point the caliper arms resume their normal rotation. The field dipmeter log records the two orthogonal hole diameters, the azimuth of hole deviation, and the azimuth of one of the caliper arms.

Four general criteria have been established in the use of non-computed dipmeter logs for identification of wellbore breakouts (Plumb and Hickman, 1985). The requirements are: 1) the tool must rotate above and below the elongated section, 2) normal tool rotation must stop within the elongated section, 3) only one caliper pair can significantly exceed the borehole diameter with respect to bit size, and 4) the direction of elongation must not coincide with the azimuth of the hole deviation.

As the interpretation of borehole elongations can be complicated to varying degrees by hole conditions, the following log characteristics were evaluated to determine whether azimuths measured over an elongated interval should be included in our statistical analysis:

a) The shape of a high quality breakout is recorded on one caliper pair trace with an abrupt beginning and end. Although azimuths for breakouts that depart from this ideal shape (described herein as "poorly shaped") were included in the analysis, they were considered less reliable.

b) Azimuths of breakouts that occur within wash-out zones (where both caliper arms record borehole diameters significantly larger than bit size) are recorded but are not included in the statistical analysis.

c) Normal tool rotation was found to vary in rate and direction depending on hole conditions and logging procedures. In some cases, minor tool rotation occurs through elongated sections where breakouts are irregularly shaped and larger than the maximum tool diameter. But if the tool did not "lock in" to a consistent orientation $\left( \pm 10^{\circ}\right)$ over that interval, the measured azimuths were considered unreliable and not included in the statistics.

d) Because the azimuth of hole deviation tends to be random for non-deviated boreholes (vertical deviation $<3^{\circ}$ ), the computed breakout azimuth may coincide with the azimuth of hole deviation. The measured breakout azimuths were considered valid for those near vertical wells in this study and were included in the statistical analysis. However, if there was significant vertical deviation throughout the hole and the breakout azimuth coincided with the azimuth of hole deviation (indicating preferential wear of the wellbore walls by the caliper tool in the direction of hole deviation), then that interval was described as a "key seat" and not included in the determination of the mean breakout direction.

\section{RESULTS}

A summary of individual log analyses for the 22 available wells is given in Table 2A (Appendix 1) which tabulates well location, breakout lengths, measured azimuth, comments on breakout quality and tool rotation, as well as the statistical results for each 
well computed using standard circular statistics for directional data (Mardia, 1972). We assigned a quality rating to the inferred directions based on standard deviation, number of breakouts, and total length of breakout intervals using the quality ranking criteria of Zoback and Zoback (1989). The detailed record of enlargements observed on the logs and of the statistical analysis are in Appendix 2.

Inferred directions of maximum horizontal stress $\left(\mathrm{S}_{\mathrm{H} \max }\right)$ were statistically significant for eight wells. Regionally consistent orientations were inferred from three additional wells, although only a small number of breakouts were observed on the logs from these wells. Results for all 11 wells are summarized in Table 1 and described in detail below. The inferred $S_{H \max }$ azimuths for these wells (keyed to the location numbers in Table 1) are plotted on the maps in Figures 1-5 along with rose diagrams for each well which illustrate the number weighted means and standard deviations.

No breakouts were observed on the logs from nine coastal wells (marked by asterisks on the map in Figure 2). In addition, the logs from two remaining wells were not interpretable and their locations are not shown on any figures.

The inferred SHmax directions plotted in Figure 1 indicate a complex pattern. The maximum horizontal stress appears to be directed $N$ to $N E$ near the south-central Washington coast and near the Canadian border, N to NNE or EW in the Puget Sound basin near Seattle, and approximately NW on the Olympic Peninsula. We interpret these inferred $\mathrm{S}_{\mathrm{Hmax}}$ directions to indicate a generally $\mathrm{N}$ to $\mathrm{NE}$ directed compression in western Washington and suggest that the complexities in the stress directions inferred within the Puget Sound region may be evidence of shallow secondary stresses acting locally in the vicinity of the wellbore, possibly in response to young deformation. Our data only poorly constrains the NW S Hmax direction on the Olympic Peninsula. The results of all wells are discussed in detail by region below with reference to Figure 2 for the fourteen southwest Washington coastal wells, Figure 3 for the single well near the Canadian border, Figure 4 for the three Puget Sound basin wells, and Figure 5 for the two wells on the Olympic Peninsula.

\section{Southwestern Coastal Washington}

The data in this region come from 5 wells and are of mixed quality but consistently indicate a $\mathrm{N}$ to $\mathrm{NNE} \mathrm{S}_{\mathrm{Hmax}}$ direction. An $\mathrm{S}_{\mathrm{Hmax}}$ direction of $\mathrm{N} 28^{\circ} \mathrm{E} \pm 7^{\circ}$ was inferred for Amoco-Weyerhauser \#1-29 (well \#5, Figure 2 and Table 1), the deepest well for which dipmeter logs were available. This well was drilled to a total depth of $3.75 \mathrm{~km}$ with less than $1^{\circ}$ of vertical deviation. It is located north of and along trend of $\mathrm{N}$ - to NNW-trending, lower to middle Miocene folds (Rau, 1967). Most breakouts were observed in the deeper section of the hole; and analysis of their shape, quality, and orientations were unambiguous.

Although Luse \#1-23 (well \#8, Figure 2 and Table 1) is a shallow well with a total depth of only $1.1 \mathrm{~km}$, we are able to infer a consistent $S_{H \max }$ direction of $\mathrm{N} 178^{\circ} \mathrm{E} \pm 9^{\circ}$ from 4 small and short breakouts observed in the deeper section of the well.

Another shallow well, Sampson Johns \#1-15 (well \#9, Figure 2 and Table 1) was drilled to a total depth of $0.85 \mathrm{~km}$ with less than $3^{\circ}$ of hole deviation. A total of 4 short elongations were observed on this well's logs, but all were in directions within $\pm 10-15^{\circ}$ of the azimuth of hole deviation and may indicate preferential wear of the borehole walls.: A poorly constrained $\mathrm{S}_{\mathrm{Hmax}}$ of $\mathrm{N} 168^{\circ} \mathrm{E}$ is inferred for this well.

Only 3 poorly shaped elongations were observed on logs from LHA \#1-15 (well \#10, Figure 2 and Table 1) which was drilled to a total depth of less than $0.50 \mathrm{~km}$. Each elongation is in a different direction causing large standard deviations for both the length and number weighted means. But the inferred $\mathrm{S}_{\mathrm{Hmax}}$ direction of $\mathrm{N} 24^{\circ} \mathrm{E} \pm 30^{\circ}$ from this well is generally consistent with inferred directions from the other wells in west central Washington.

Data from Montesano \#1 (well \#11, Figure 2 and Table 1) yielded an $S_{H \max }$ direction of $\mathrm{N} 167^{\circ} \mathrm{E} \pm 8^{\circ}$ from 5 long intervals of small, poorly shaped breakouts. The 
total length of breakouts is $213 \mathrm{~m}$ over a $1500 \mathrm{~m}$ depth range with hole deviation generally less than $2^{\circ}$. The well is located near the Chehalis River in unconsolidated alluvium overlying lower to middle Miocene sedimentary rocks on trend with the crest of the northstriking Melbourne anticline which deforms middle Tertiary and older strata (Gower and Pease, 1965).

Although the breakout data are of mixed quality, the modern $\mathrm{S}_{\mathrm{Hmax}}$ direction inferred from the breakout analysis consistently trends $\mathrm{N}$ to $\mathrm{NE}$. This is in contrast to geologic evidence of probable Miocene age E-W compression in the southwest coastal region of Washington (Rau, 1967) and episodic Quaternary compressional deformation along the continental slope offshore consistent with oblique subduction and approximate EW shortening (Snavely, 1987; Snavely and Wells, 1991).

\section{Canadian border region}

An $\mathrm{S}_{\mathrm{Hmax}}$ direction of $\mathrm{N}^{\circ} \mathrm{E} \pm 19^{\circ}$ was inferred from analysis on breakouts in Birch Bay \#1 (well \#1, Figure 3 and Table 1) which is located about $2 \mathrm{~km}$ east of Birch Bay, near the Canadian border in the far northern part of Puget Sound. The well was drilled to a total depth of $2.78 \mathrm{~km}$ and was situated on the north flank of a broad, generally E-trending fold (Easterbrook, 1976). A total of 17 breakouts were observed over a $1.80 \mathrm{~km}$ depth interval in the hole. Each enlargement interpreted as a breakout generally had an abrupt beginning and end, with clear tool rotation above and below the enlarged wellbore interval. The hole was logged in two runs; the log from the deeper section $(1.996-2.585 \mathrm{~km})$ shows the hole to be increasingly deviated from the vertical by $3^{\circ}$ to $7^{\circ}$ with the tool encountering more hole problems and getting stuck with a consequent loss of recorded azimuths. This is the only well for which a lithology log was acquired. Rocks penetrated by the well are predominantly a mix of sandstones, shales, and siltstones with the exception of a $138 \mathrm{~m}$ thick igneous sill at $0.70 \mathrm{~km}$ depth. There is no obvious correlation of breakout shape or orientation with lithology.

\section{Puget Sound Basin}

Stress orientations were obtained from three wells (\#2-4, Figure 4), the breakouts occurred in consolidated Tertiary bedrock consisting of conglomerates, sandstones, shales, and some volcanic rocks (Gower et al, 1985) which underlie the shallow unconsolidated Quaternary basin fill as interpreted from a variety of geophysical and geological data (Yount and others, 1985; Danes and others, 1965). The $S_{H \max }$ orientations inferred from breakouts observed in these wells are shown in Figure 4 along with two major tectonic features identified by Gower and others (1985) in the Puget Sound region. On the basis of gravity and magnetic anomalies as well as mapped Quaternary deformation, Gower and others (1985) have identified the NW-trending Whidbey Island fault and an E-W-trending, E-plunging anticline, these structures are identified as active in Cenozoic time, although the details of their timing and sense of movement are largely unresolved. No surface fault exposures have been described in the literature for the Puget Sound basin region; much of the near surface deformation appears related to broad folding and warping. Bucknam (1991) has described $7 \mathrm{~m}$ of warping and uplift of a marine terrace dated at less than about $1500 \mathrm{cal} \mathrm{yr} \mathrm{B.P.} \mathrm{on} \mathrm{Bainbridge} \mathrm{Island} \mathrm{located} \mathrm{to} \mathrm{the} \mathrm{south} \mathrm{of} \mathrm{the} \mathrm{area} \mathrm{shown} \mathrm{in} \mathrm{Figure} 4$. This warping has been ascribed to compressional deformation associated with an approximately $\mathrm{E}-\mathrm{W}$ trending buried reverse fault.

An $\mathrm{S}_{\mathrm{Hmax}}$ orientation of $\mathrm{N}^{\circ} 5^{\circ} \mathrm{E} \pm 10^{\circ}$ is inferred at Whidbey \#1 (well \#2, Figure 4 and Table 1). This well is located on the northern, down-dropped side of the inferred WNW-trending southern Whidbey Island fault. Although the actual fault trace and sense of slip are poorly constrained, possible offset Holocene marine sediments have been interpreted from seismic reflection profiles near its northwestern termination (Wagner and Wiley, 1980; Gower and others, 1985). Drilled to a total depth of $2.04 \mathrm{~km}$, a large portion 
of the well is washed out. Twenty-two elongations occur over the depth range of 0.335 $2.042 \mathrm{~km}$ but only 9 are considered to be high quality breakouts and these occur in a single interval between 1.531 and $1.794 \mathrm{~km}$. A second, subsidiary set of breakout orientations with a mean direction of $\mathrm{N} 110^{\circ} \mathrm{E} \pm 21^{\circ}$ occurs in the shallow portion of the well between 0.353 and $0.774 \mathrm{~km}$ depth. This subsidiary set consists of 5 generally lower quality breakout zones; one of which exhibits slow tool rotation throughout its $201 \mathrm{~m}$ length.

The Whidbey \#1 well and the Birch Bay \#1 well in the Canadian border region indicate a generally NNE-directed $S_{H \max }$, consistent with mapped geologic structures (Wagner and Wiley, 1980; Gower and others, 1985; Easterbrook, 1976). However, two wells directly south of the Whidbey \#1 well give contrasting results. These two wells, Kingston \#1 and Schroeder \#1 (well \#3 and \#4, Figure 4 and Table 1), indicate roughly E$\mathrm{W}$ trending $\mathrm{S}_{\mathrm{Hmax}}$ directions. Both were drilled near an E-trending gravity high interpreted to be an E-trending, E-plunging anticline with possible Quaternary movement (Gower and others, 1985).

A mean $S_{H \max }$ azimuth of $N 115^{\circ} \pm 16^{\circ}$ was inferred for Kingston \#1 (well \#3), located near the axis of the anticline. Kingston \#1 was drilled to total depth of $2.64 \mathrm{~km}$ with less than $2^{\circ}$ vertical deviation and a randomly varying azimuth of hole deviation, but good quality breakouts were observed over only a relatively shallow interval of 0.50 to $1.52 \mathrm{~km}$. From a summary of the lithology log (R. Dart, 1990, personal communication) elongations were observed predominantly in sandy claystones and siltstones, with the exception of an $8 \mathrm{~m}$ interval of volcanic tuff. Measured breakout azimuths are not correlated with the reported lithologies.

Schroeder \#1 (well \#4), drilled to total depth of $2.95 \mathrm{~km}$, is located on the southern limb of the inferred anticline as shown in Figure 4. Two distinct breakout sets were observed on the logs from this well, but only the dominant $S_{H m a x}$ orientation of $N 88^{\circ} \mathrm{E} \pm$ $15^{\circ}$ which was inferred from the deeper section of the well is plotted in Figures 1 and 4 . Although the means for the two sets of breakout orientations are internally consistent, these two sets have orientations which are $60^{\circ}$ apart and the change in azimuth occurs near casing between logging runs 2 and 3 . The shallow trend is defined by 9 poorly shaped breakouts with a total length of only $150 \mathrm{~m}$ while the deeper trend is defined by 13 good quality breakouts with a total length of over $400 \mathrm{~m}$. Also, in the shallow interval of the hole the average azimuth of hole deviation is approximately equal to the elongation azimuth; although the recorded azimuth of hole deviation may not reflect a preferential orientation for wellbore wear because the borehole deviates less than $2^{\circ}$ from the vertical.

The $\mathbf{N}$ to NNE SHmax directions inferred from Birch Bay \#1 and Whidbey \#1 wells are in good agreement with the regional maximum compression direction inferred from focal mechanisms (Ma, 1988; Ma and others, 1991; Zoback and Zoback, 1989) and numerous other EW-trending folds and reverse faults, as well as NW- and NE-trending faults which have been mapped in the Puget sound region; (see summary of these features in Gower and others, 1985). The E-trending anticline and other E-W structural trends in Puget Sound (Bucknam, 1991; Gower and others, 1985) are also consistent with a $\mathbf{N}$ to NNE compressive stress within the basin. However, $S_{H m a x}$ directions inferred from analysis of breakouts in the Kingston \#1 and Schroeder \#1 wells are approximately perpendicular to this regional stress direction. In detail, the inferred $\mathrm{S}_{\mathrm{Hmax}}$ directions from Kingston \#1 and Schroeder \#1 parallel the axis of the anticlinal fold into which they were drilled, suggesting that the inferred stress directions may be dominated by this neotectonic structure.

It is interesting to note that there is considerable complexity in the regional gravity map of the Puget Sound basin. It may be that these scattered and inconsistent SHmax directions are due to local perturbations of the regional stress field caused by lateral density variations beneath the basin. Another possibility is that extensional flexural stresses in the uppermost layers of an actively deforming fold above a buried fault are relatively large. Thus, the orientations of the borehole elongations from these two wells are indicating local extensional stresses perpendicular to the trend of the fold at its crest, analogous to the 
extensional fractures observed at the surface above the 17 October 1989 Loma Prieta, California rupture (Cotton and others, 1990; Zoback and Reches, 1990).

\section{Olympic Peninsula}

Due to a lack of availability, logs were analyzed for only two Olympic Peninsula wells. Shearing \#1 (well \#6, Figure 5 and Table 1) was drilled to a total depth of $1.5 \mathrm{~km}$ on the crest of the Mosquito Creek anticline. The well was sited close to a change in anticlinal trend from generally NNW to more WNW and adjacent to the cross-cutting NEtrending Oil City fault, a possibly reverse or strike-slip fault that offsets the mid-Tertiary fold (Rau, 1979). The wellbore is deviated about $4^{\circ}$ from the vertical over most of it depth, and azimuths of observed elongations in the upper part of the well coincide with the azimuth of hole deviation. Only 4 small well-shaped breakouts were observed on the logs and the total length of breakouts is short, only about $42 \mathrm{~m}$. Thus, although the length and number weighted mean directions of the 4 breakouts are consistent, the SHmax direction of $\mathrm{N} 110^{\circ} \mathrm{E} \pm 7^{\circ}$ is considered to be marginally reliable.

The other Olympic peninsula well, State \#1-30 (well \#7, Figure 5 and Table 1), was drilled to total depth of $2.01 \mathrm{~km}$ in a complex structural setting where folded sedimentary rocks pinch out against an EW-striking fault with an undetermined sense of slip due to poor exposures and structurally complex bedrock relationships (Brown and others, 1960; Tabor and Cady, 1978). Elongations occur over the depth range of $0.67 \mathrm{~km}$ to total depth, but the well deviates from the vertical by $2^{\circ}$ to as much as $7^{\circ}$ at depth and the azimuths of the elongations measured in the deeper section coincide with the azimuth of hole deviation. Only 4 well shaped breakouts with a total length of $52 \mathrm{~m}$ are observed over a $300 \mathrm{~m}$ section of the hole. The length and number weighted means are again consistent but because of the short breakout length the inferred $S_{H \max }$ direction of $\mathrm{N} 155^{\circ} \mathrm{E} \pm 10^{\circ}$ is considered to be only marginally reliable.

As discussed above, the $S_{H \max }$ directions for the Olympic Peninsula inferred from wells \#6 and \#7 may not be significant because so few breakouts were observed in each well over a relatively short interval. Although the inferred directions are consistent within each well as indicated by the low standard deviations and similar length-weighted and number-weighted means, they differ from each other by $45^{\circ}$ and only weakly constrain the $\mathrm{S}_{\text {Hmax }}$ direction to lie in the NW quadrant. Breakouts observed in both wells are from reasonable depth ranges, on the order of $1 \mathrm{~km}$, but the state of stress in this region remains poorly constrained.

\section{DISCUSSION}

The orientation of $S_{H \max }$ as inferred from breakouts throughout the Puget Sound basin presents a puzzling pattern that could interpreted to imply either E-W or N-S directed compression. However, as described below the inferred E-W $S_{H m a x}$ directions appear to be a shallow effect that is locally associated with an E-W trending gravity high. This ridgelike high on the regional Bouguer gravity anomaly map is located south of the Whidbey fault and has been interpreted as an E-trending, E-plunging anticline (Gower and others, 1985) as shown in Figure 4.

To illustrate the apparent association of inferred E-W $S_{\text {Hmax }}$ directions with shallow depth in the vicinity of the plunging anticline, rose diagrams of length-weighted means and graphs of breakout azimuth with depth are plotted. Figure 6 shows the data for those well which indicate a generally E-W breakout orientation (implying an approximate N-S $S_{\mathrm{Hmax}}$ ) and Figure 7 shows the data for those wells with generally $\mathrm{N}-\mathrm{S}$ oriented breakouts (implying an approximate E-W S $S_{\text {max }}$ ). North of the Whidby fault, breakout orientations from below $1.5 \mathrm{~km}$ depth in Whidbey \#1 are consistent with NNE directed compression. While south of the Whidby fault, the $S_{\text {Hmax }}$ inferred from oriented breakouts between 0.5 km and $2.9 \mathrm{~km}$ depths at Kingston \#1 and Schroeder \#1 (both shallow and deep trends) 
scatter about $\mathrm{N} 116^{\circ} \mathrm{E} \pm 30^{\circ}$ as do the breakouts in the shallow (less than $1.5 \mathrm{~km}$ ) section of the Whidbey \#1 well. The only well drilled deeper than $3 \mathrm{~km}$, Amoco-Weyerhauser \#1, located outside the Puget Basin in southwestern Washington, yielded a well resolved breakout orientations that implies an $S_{H \max }$ consistent with the deeper Whidbey \#1 orientation. North of the Puget Sound basin, breakouts in the Birch Bay \#1 well, are also consistent with a generally NS $S_{\text {Hmax }}$ direction.

Additional constraints on the stress field within the Puget Sound basin have been inferred from earthquake focal mechanisms. Ma and others (1991) inverted 76 focal mechanisms from $M>1$ crustal earthquakes in the depth range of 3 to $30 \mathrm{~km}$ for the state of stress in the crust beneath the Puget Sound. They found the maximum principal compressive stress, $\sigma_{1}$, to be subhorizontal and directed generally $\mathrm{N}-\mathrm{S}$. Their composite plot of $\mathrm{P}$ and $\mathrm{T}$ axes for all 76 crustal earthquakes suggests that the intermediate principal stress, $\sigma_{2}$, is comparable in magnitude to the minimum principal compressive stress, $\sigma_{3}$, implying an uniaxial state of stress, a combination strike-slip/thrust faulting stress regime. Only the deep breakout orientations from the Amoco-Weyerhauser \#1 well in southwestern Washington occur below $3 \mathrm{~km}$ depth and sample the upper part of the depth range where the crustal earthquakes occur; however, the inferred $S_{\text {Hmax }}$ direction from AmocoWeyerhauser \#1, Birch Bay \#1, and the deeper section of the Whidbey \#1, and the 4 coastal wells (Shell Luse \#1-23, Sampson John's \#1-15, Gray's Harbor LHA \#1-15, and Montesano \#1-X) are all generally consistent with the stress field inferred from the earthquake focal mechanisms.

Regionally, the crustal stress field as inferred from our breakout analysis suggests a $\mathrm{N} 20^{\circ} \mathrm{E}$ oriented maximum horizontal compression near the southwestern Washington coast that becomes more northerly within the Puget Sound basin. As noted above, this $\mathbf{N}$ to NNE maximum horizontal compression is consistent with focal mechanisms of crustal earthquakes beneath Puget Sound (Yelen, 1982; Ma, 1988; Ma and other, 1991) and is also consistent with generally $\mathrm{N}$-trending $\mathrm{S}_{\mathrm{H} \text { max }}$ directions in western Oregon inferred from wellbore breakouts and volcanic alignments (Werner and others, 1991). This state of stress is also consistent with the stress state in the eastern portions of the state Zoback and Zoback $(1989,1991)$. Spence (1989) suggested that this $\mathrm{N}$ to NNE compression was due to the Pacific plate colliding with the Juan de Fuca offshore plate system, with much of the resulting compression transferred into the continental plate. His conclusion was based on finite element modeling of stresses due to plate motion displacements however, much of his predicted stress pattern appears to be strongly influenced by an artificial E-W boundary forming the northern edge of his model. Previously, Sbar (1982) and Zoback and Zoback $(1989,1991)$ have suggested that the generally northerly compression observed throughout the Pacific Northwest is related to a broad zone of NW oriented, right-lateral shear arising from Pacific-North American relative plate motion.

Interestingly, the $\mathrm{N}$ to NNE compression along southwestern coastal Washington and in the Puget Sound is inconsistent with NE to ENE compression which would be inferred from strong coupling with the obliquely subducting Juan de Fuca plate. Geodetic strain data suggest maximum horizontal strain accumulation in a $\mathrm{N} 68^{\circ} \mathrm{E}$ direction near Seattle and $\mathrm{N}^{\circ} 9^{\circ} \mathrm{E}$ on the Olympic Peninsula (Savage and others, 1991). Both strain measurements are consistent with uniaxial contraction in the direction of plate convergence (approximately $\mathrm{N} 68^{\circ} \mathrm{E}$, DeMets and others 1990). While strain may be accumulating at depth on this subduction zone, the state of stress in the crust beneath Puget Sound both at shallow levels (upper few kilometers from breakouts and geologic structure) and deeper levels (18-28 km, depth of most earthquakes) appears unrelated to shear tractions due to this convergence. The available stress data throughout Washington state indicate a regional uniaxial compression directed $\mathrm{N}$ to $\mathrm{NNE}$ and a strike-slip/thrust stress regime. The apparent orthogonal rotation of the regional $\mathrm{N}$ to $\mathrm{NNE}$ uniaxial compression locally within the Puget Sound basin suggests that the local stress perturbation is large compared to the regional horizontal stress magnitudes at these depths (Zoback, 1992). 


\section{CONCLUSIONS}

Our analysis of non-computed dipmeter logs for petroleum wells in the western part of Washington state indicates that the maximum horizontal stress is directed about $\mathrm{N} 20^{\circ} \mathrm{E}$ near the south-central Washington coast, $\mathbf{N}$ to NNE within Puget Sound basin, and generally NW on the Olympic peninsula. This stress state is consistent with geophysical and geologic evidence of young generally E- to ENE-trending compressional structures including folds and probable reverse faults throughout the Puget Sound basin. That the maximum horizontal compressive stress directions inferred from breakouts in two wells drilled within the Puget Sound basin are orthogonal to the regional trend is problematic, but appears to be a local shallow effect. We suggest that these inferred $S_{H \max }$ directions may be due to local perturbations to the regional stress field active in the vicinity of the wellbore, possibly in response to the effects of young deformation or lateral density contrasts.

Within western Washington, the regional crustal stress field is inconsistent with the geodetic strain measured on the Olympic Peninsula, where the deformation rates are interpreted as ENE uniaxial contraction consistent with the direction of subduction of the Juan de Fuca plate. While strain may be accumulating on the subduction zone beneath the Puget Sound region, upper crustal earthquake focal mechanisms, wellbore breakouts, and young geologic structures are all consistent with the $\mathrm{N}$ to NNE $\mathrm{S}_{\mathrm{Hmax}}$ direction. Potential seismicity related to this $\mathrm{N}$ to $\mathrm{NNE}$ compression and ongoing deformation of the upper crust must not be ignored in the assessment of earthquake hazard of the Puget SoundSeattle region.

Acknowledgments. We are grateful to Richard Dart (USGS Denver) for providing lithology log information for the Kingston \#1 well and to Meridian Oil \& Gas, Inc. for providing us with copies of logs for the Plum Creek \#23-2 well prior to public release. We thank Michael Lisowski and Brian Atwater for constructive reviews. The Nuclear Regulatory Commission provided funding for the breakout analysis and interpretation. 


\section{REFERENCES}

Brown, Jr., R. D., H. D. Gower, and P. D. Snavely, Jr., 1960, Geology of the Port Angeles-Lake Crescent area, Clallum County, Washington: U. S. Geological Survey Oil and Gas Investigation Map OM-203, scale 1:62,500, map and text on 1 sheet.

Bucknam, R. C., 1991, Puget Sound paleoseismicity, U. S. Geological Survey Open File Report 91-352, p. 526-527.

Cotton, W. R., W. L. Fowler, and J. E. Van Velsor, 1990, Coseismic bedding plane faults and ground fissures associated with the Loma Prieta earthquake of 17 October, 1989: California Division of Mines and Geology Special Publication 104, p. 95-103.

Danes, Z. F., 1985, Sedimentary thickness in the Puget Sound area, Washington, derived from aeromagnetic data: State of Washington, Department of Natural Resources, Division of Geology and Earth Resources Open File Report 85-5, p. 1-14.

DeMets, C., R. G. Gordon, D. F. Argus, and S. Stein, 1990, Current plate motions: Geophysical Journal International, v. 101, p. 425-478.

Easterbrook, D. J., 1976, Geologic map of western Whatcom County, Washington: U. S. Geological Survey Miscellaneous Investigation Map I-854-B, scale 1:62,500, map and text on 1 sheet.

Gough, D.I., and J.S. Bell, 1981, Stress orientations from oil well fractures in Alberta and Texas, Can. J. Earth Sci., v. 18, p. 1358-1370.

Gower, H. D., and M. H. Pease, Jr., 1965, Geology of the Montesano Quadrangle, Washington: U. S. Geological Survey Geologic Quadrangle Map GQ-374, scale 1:62,500, map on 1 sheet.

Gower, H. D., J. C. Yount, and R. C. Crosson, 1985, Seismotectonic map of the Puget Sound region, Washington, U. S. Geological Survey Miscellaneous Investigation Map I-1613, 15 pp., scale 1:250,000, map on 1 sheet.

Hickman, S. H., J. H. Healy, and M. D. Zoback, 1985, In situ stress, natural fracture distribution and borehole elongation in the Auburn geothermal well, Auburn, New York, J. Geophys. Res., v. 90, p. 5497-5512.

Ma, L., 1988, Regional tectonic stress in western Washington from focal mechanisms of crustal and subcrustal earthquakes, M.S. thesis, Univ. of Washington, $84 \mathrm{pp}$.

Ma, L., R. Crosson, and R. Ludwin, 1991, Focal mechanisms of western Washington earthquakes and their relationship to regional tectonic stress, U. S. Geological Survey Open File Report 91-441-D, 38 pp.

Mardia, K. V., 1972, Statistics of Directional Data, 357 pp., Academic Press, San Diego, CA.

McFarland, C. R., 1983, Oil and Gas Exploration in Washington, 1900-1982, State of Washington, Department of Natural Resources, Division of Geology and Earth Resources Circular 75, 119 pp. 
Molnar, P. and T. Atwater, 1978, Interarc spreading and Cordilleran tectonics as alternates related to the age of subducted oceanic lithosphere, Earth and Planetary Science Letters, v. 41, p. $330-340$.

Plumb, R. A. and J.W. Cox, 1987, Stress directions in eastern North America determined to $4.5 \mathrm{~km}$ from borehole elongation measurements, J. Geophys. Res., v. 92, p. 48054816.

Plumb, R. A. and S. H. Hickman, 1985, Stress-induced borehole elongation: A comparison between the four-arm dipmeter and the borehole televiewer in the Auburn geothermal well, J. Geophys. Res., v. 90, p. 5513-5521.

Rau, W. W., 1967, Geology of the Wynoochee Valley Quadrangle, Grays Harbor County, Washington: State of Washington, Department of Natural Resources, Division of Geology and Earth Resources Bulletin no. 56, 51 pp., scale 1:62,500, map on 1 sheet.

Riddihough, R. P., 1984, A model for recent plate interactions off Canada's west coast: Canadian Journal of Earth Sciences, v. 14, p. 384-396.

Savage, J. C., Lisowski, M., and Prescott, W. H., 1991, Strain accumulation in western Washington, Journal of Geophysical Research, v. 96, p. 14493-14507.

Sbar, M. L., 1982, Delineation and interpretation of seismotectonic domains in western North America, Journal of Geophysical Research, v.87, p. 3919-3928.

Snavely, P. D., Jr., 1997, Tertiary geologic framework, neotectonics, and petroleum potential of the Oregon-Washington Continental Margin, in Scholl, D. W., A. Grantz, and J. G. Vedder, eds., Geology and resource potential of the continental margin of western North America and adjacent ocean basins--Beaufort Sea to Baja California: Houston, Texas, Circum-Pacific Council for Energy and Mineral Resources, Earth Science Series, V. 6, p. 305-335.

Snavely, P. D., Jr., and Wells, R. E., 1991, Cenozoic evolution of the continental margin of Oregon and Washington, U. S. Geological Survey Open File Report 91-441-B, 34 pp.

Spence, W., 1989, Stress origins and earthquake potentials in Cascadia, Journal of Geophysical Research, v. 94, p. 3076-3088.

Tabor, R. W., and W. M. Cady, 1978, Geologic map of the Olympic Peninsula, scale 1:125,000, U. S. Geological Survey Miscellaneous Investigations Map I-994.

Werner, K. S., E. P. Graven, T. A. Berkman, and M. J. Parker, 1991, Direction of maximum horizontal compression in western Oregon determined by borehole breakouts, Tectonics, v. 10, p. 948-958.

Wagner, H. C., and M. C. Wiley, 1980, Preliminary map of offshore geology in the Protection Island-Point Partridge area, northern Puget Sound, Washington, U. S. Geological Survey Open File Report 80-548, 4 pp.

Yelen, T. S., 1982, The Seattle earthquake swarms and Puget Basin focal mechanisms and their tectonic implications, M.S. thesis, Univ. of Washington, $96 \mathrm{pp}$. 
Yount, J. C., G. R. Dembroff, and G. M. Barats, 1985, Map showing depth to bedrock in the Seattle $30^{\prime}$ by $60^{\prime}$ quadrangle, Washington, scale $1: 100,000$, U. S. Geological Survey Miscellaneous Field Studies Map MF-1692.

Zoback, M.D., D. Moos, L. Mastin and R. N. Anderson, 1985, Wellbore breakouts and in situ stress, Journal of Geophysical Research, v. 90, p. 5523-5530.

Zoback, M. D. and Z. Reches, 1990, Application of a layered media model to surface deformation associated with the Loma Prieta earthquake, 1989, EOS (Trans. American Geophysical Union), v. 71, p. 1652.

Zoback, M. D., and M. L. Zoback, 1991, Tectonic stress field of North American and relative plate motions: Geological Society of America DNAG series, Neotectonics of North America volume I, p. 339-366.

Zoback, M. L., and M. D. Zoback, 1989, Tectonic stress field of the conterminous United States, Geol. Soc. Am. Memoir, 172, p. 523-539.

Zoback, M. L., 1992, First and second-order patterns of stress in the lithosphere: the World Stress Map project, Journal of Geophysical Research, v. 97, p. 11703-11728. 


\section{TABLE 1}

Wellbore Breakout Analysis--Washington State

\begin{tabular}{|c|c|c|c|c|c|c|}
\hline $\begin{array}{c}\text { Well } \\
\text { Number }\end{array}$ & $\begin{array}{l}\text { Well } \\
\text { er Name }\end{array}$ & $\begin{array}{c}\text { SHmax orientation } \\
\pm \text { Standard } \\
\text { Deviation }\end{array}$ & $\begin{array}{c}\text { Number } \\
\text { of BO } \\
\text { Intervals }\end{array}$ & $\begin{array}{l}\text { Total } \\
\text { Length } \\
\text { (m) }\end{array}$ & $\begin{array}{l}\text { Depth } \\
\text { Range } \\
\text { (km) }\end{array}$ & Structural Setting \\
\hline $1 \mathrm{~B}$ & Birch Bay \#1 & $\mathrm{N} 5^{\circ} \mathrm{E} \pm 19^{\circ}$ & 17 & 211 & $0.366-2.166$ & $\begin{array}{l}\text { on north limb of } \\
\text { broad E-trending } \\
\text { anticlinal fold }\end{array}$ \\
\hline 2 & $\begin{array}{l}\text { Whidbey \#1 } \\
\text { 1st set } \\
\text { 2nd set }\end{array}$ & $\begin{array}{l}\mathrm{N} 15^{\circ} \mathrm{E} \pm 10^{\circ} \\
\mathrm{N} 101^{\circ} \mathrm{E} \pm 25^{\circ}\end{array}$ & $\begin{array}{l}9 \\
5\end{array}$ & $\begin{array}{l}184 \\
359\end{array}$ & $\begin{array}{l}1.532-2.047 \\
0.353-0.774\end{array}$ & $\begin{array}{l}\text { on north, down-dropped } \\
\text { side of NW-striking } \\
\text { Whidbey Is. fault }\end{array}$ \\
\hline 31 & Kingston \#1 & $\mathrm{N} 113^{\circ} \mathrm{E} \pm 16^{\circ}$ & 14 & 560 & $0.506-1.328$ & $\begin{array}{l}\text { on axis of gravity high } \\
\text { interpreted as E-striking, } \\
\text { E-plunging anticline }\end{array}$ \\
\hline $4 S$ & $\begin{array}{l}\text { Schroeder \#1 } \\
1 \text { st set } \\
2 \text { nd set }\end{array}$ & $\begin{array}{l}\mathrm{N} 89^{\circ} \mathrm{E} \pm 15^{\circ} \\
\mathrm{N} 146^{\circ} \mathrm{E} \pm 13^{\circ}\end{array}$ & $\begin{array}{c}13 \\
9\end{array}$ & $\begin{array}{l}465 \\
153\end{array}$ & $\begin{array}{l}2.137-2.861 \\
0.650-2.024\end{array}$ & $\begin{array}{l}\text { on south limb, } \\
\text { near nose of inferred } \\
\text { E-striking, E-plunging } \\
\text { anticline }\end{array}$ \\
\hline 5 & $\begin{array}{c}\text { Amoco- } \\
\text { Weyerhauser \#1 }\end{array}$ & $\mathrm{N} 28^{\circ} \mathrm{E} \pm 7^{\circ}$ & 19 & 205 & $1.731-3.741$ & $\begin{array}{l}\text { north of NW-striking } \\
\text { syncline }\end{array}$ \\
\hline 6 & Shearing \#1 & $\mathrm{N} 110^{\circ} \mathrm{E} \pm 7^{\circ}$ & 4 & 42 & $1.158-1.251$ & $\begin{array}{l}\text { on axis of NNW-WNW } \\
\text { trending anticline, near } \\
\text { end cut by NE-striking } \\
\text { fault }\end{array}$ \\
\hline 7 & State \#30-1 & $\mathrm{N} 155^{\circ} \mathrm{E} \pm 9^{\circ}$ & 4 & 52 & $0.939-1.225$ & $\begin{array}{l}\text { on } \mathrm{N} \text { limb of E-trending } \\
\text { syncline where beds pinch } \\
\text { out against E-striking } \\
\text { fault }\end{array}$ \\
\hline 8 & Luse \#1-23 & $\mathrm{N} 175^{\circ} \mathrm{E} \pm 10^{\circ}$ & 4 & 36 & $0.556-0.845$ & $\begin{array}{l}\text { shallow well } \\
\text { no structural info }\end{array}$ \\
\hline 9 & $\begin{array}{l}\text { Sampson } \\
\text { Johns \#1-15 }\end{array}$ & $\mathrm{N} 168^{\circ} \mathrm{E}$ & 2 & 21 & $0.386-0.463$ & $\begin{array}{l}\text { shallow, coastal well } \\
\text { no structural info }\end{array}$ \\
\hline 10 & LHA \#1-15 & $\mathrm{N} 14^{\circ} \mathrm{E} \pm 30^{\circ}$ & 3 & 41 & $0.165-0.471$ & $\begin{array}{l}\text { shallow, coastal well } \\
\text { no structural info }\end{array}$ \\
\hline 11 & $\begin{array}{c}\text { Montesano } \\
\# 1-X\end{array}$ & $\mathrm{~N} 167^{\circ} \mathrm{E} \pm 8^{\circ}$ & 5 & 296 & $0.213-1.688$ & $\begin{array}{l}\text { on trend with axis of } \\
\mathrm{N} \text {-trending anticline }\end{array}$ \\
\hline
\end{tabular}




\section{FIGURE CAPTIONS}

Figure 1: Map of western Washington showing $\mathrm{S}_{\mathrm{Hmax}}$ orientations inferred from wellbore breakout analysis. Boxes outline the approximate areas included in Figures 2 through 5. The length of the oriented lines for stress directions are proportional to quality. The geodetically measured strain (as reported by Savage and others, 1991) is also shown with the direction of principal contraction indicated by the lined inward pointing arrow and the direction of principal extension indicated by the thin outward pointing arrows. The large black arrow offshore indicates the direction of plate convergence between the Juan de Fuca and North American plates along the Cascadia subduction zone as determined by DeMets and others (1990). Major volcanoes of the Cascade range are indicated by gray asterisks. These are designated Ba - Mt. Baker, Gl - Glacier Peak, Ra - Mt. Rainier, Ti - Tieton Peak, Sa - Mt. St. Helens, Ad - Mt. Adams, and Gi - Gifford Peak.

Figure 2: Map of coastal Washington in the vicinity of Gray' Harbor showing $\mathrm{S}_{\mathrm{Hmax}}$ orientations inferred from breakouts in wells \#5, \#8, \#9, \#10, and \#11. Asterisks mark the approximate locations of wells which yielded no breakout information. The azimuth of each breakout orientation is drawn in the rose diagrams for each well (keyed to the map by the location numbers in Table 1). The radius ( $r$ ) of each rose diagram and the total number of breakouts (n) are indicated for each well along with the inferred directions of $\mathrm{S}_{\mathrm{Hmin}}$ and S Hmax.

Figure 3: Map of the Washington-Canadian border north of Puget Sound showing the $S_{\text {Hmax }}$ orientation inferred from breakouts in wells \#1. Rose diagrams and statistical information as in Figure 2.

Figure 4: Map of Puget Sound region showing $S_{\mathrm{Hmax}}$ orientations inferred from breakouts in wells \#2, \#3, and \#4. The Whidbey Island fault (identified from gravity, aeromagnetic, and geologic data ) and an EW-trending anticline (associated with an E-trending gravity high) are also shown. Rose diagrams and statistical information as in Figure 2.

Figure 5: Map of the Olympic Peninsula showing $S_{\text {Hmax }}$ orientations inferred from breakouts in wells \#6 and \#7. Rose diagrams and statistical information as in Figure 2.

Figure 6: The azimuth of wellbore elongations are plotted with respect to depth for the three wells which yielded well constrained NS S Hmax directions. The rose diagrams illustrate the azimuthal variations associated with breakout length as the radius ( $r$ ) of the rose diagrams are scaled by the length in meters indicated; total length (len) of elongations, and the length weighted means and standard deviations for the inferred $\mathrm{S}_{\mathrm{Hmin}}$ and $\mathrm{S}_{\mathrm{Hmax}}$ are also listed.

Figure 7: The azimuth of wellbore elongations are plotted with respect to depth for the three wells which yielded well-constrained EW SHmax directions. The rose diagrams illustrate the azimuthal variations associated with breakout length as the radius (r) of the rose diagrams are scaled by the length in meters indicated; total length (len) of elongations, and the length weighted means and standard deviations for the inferred $\mathbf{S}_{\mathrm{Hmin}}$ and $\mathrm{S}_{\mathrm{Hmax}}$ are also listed. 


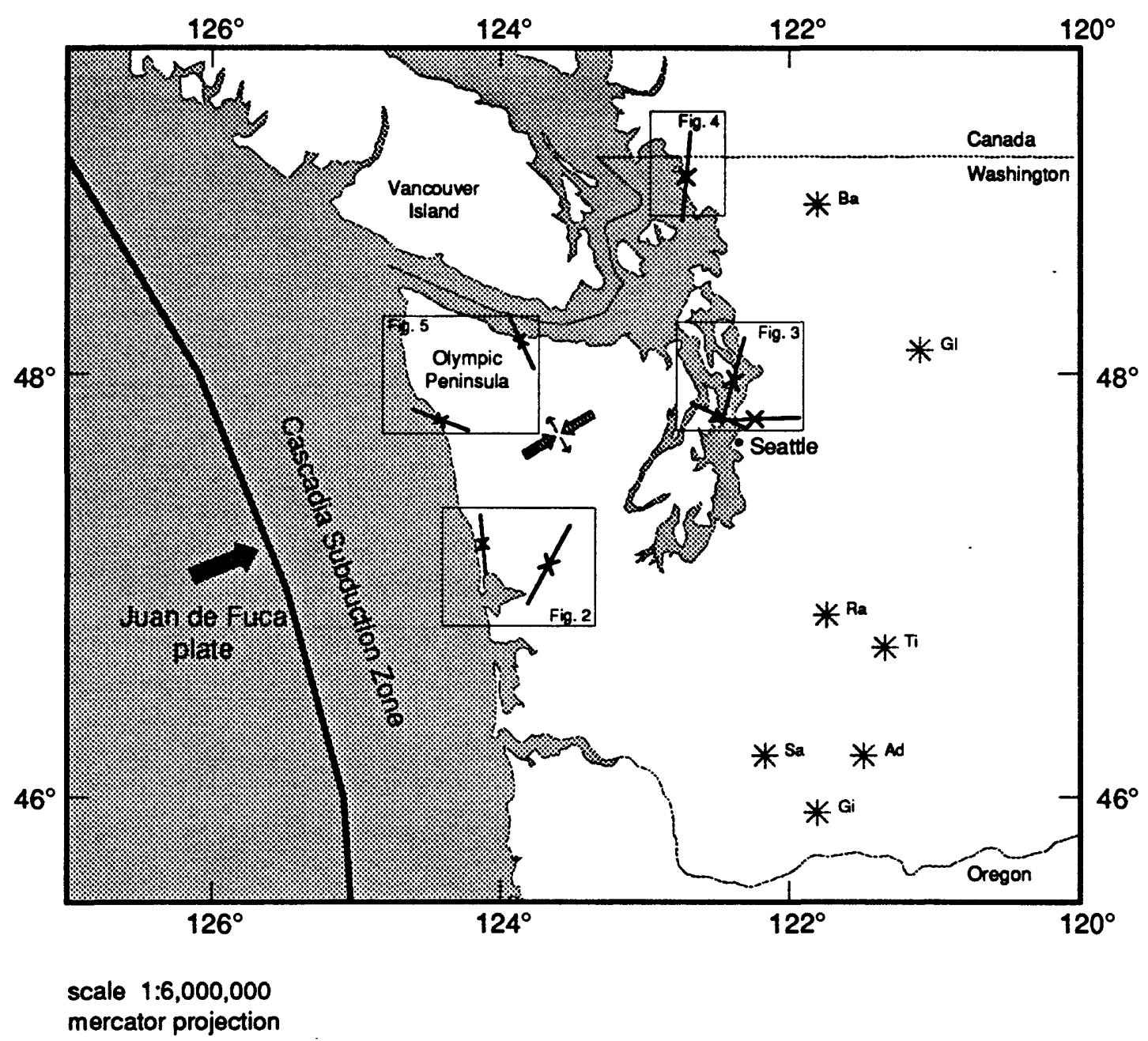

Figure 1 
8 Shell Luse \#1-23

$n=4 \quad r=3$

Shmin $=\mathrm{N}^{\circ} 5 \mathrm{E}^{\circ} \pm 10^{\circ}$

$S H \max =N 175^{\circ} \mathrm{E} \pm 10^{\circ}$
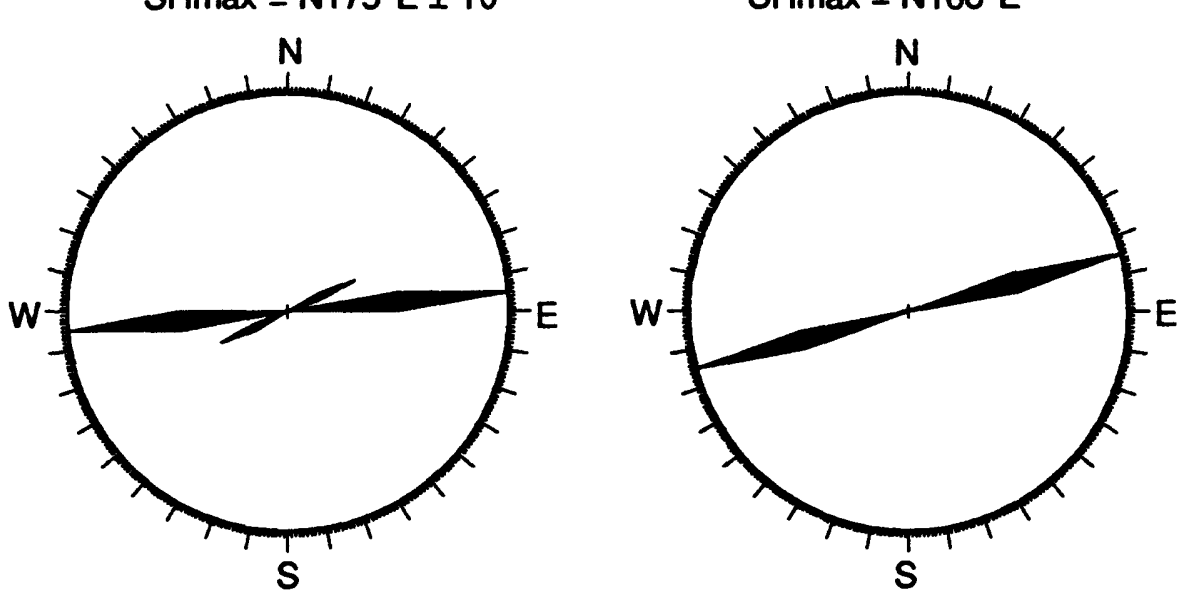

John's \#1-15

$n=2 \quad r=2$

Shmin $=N 78^{\circ} \mathrm{E}$

$\mathrm{SHmax}=\mathrm{N} 168^{\circ} \mathrm{E}$

$47^{\circ}$

$47^{\circ} 20^{\prime}$

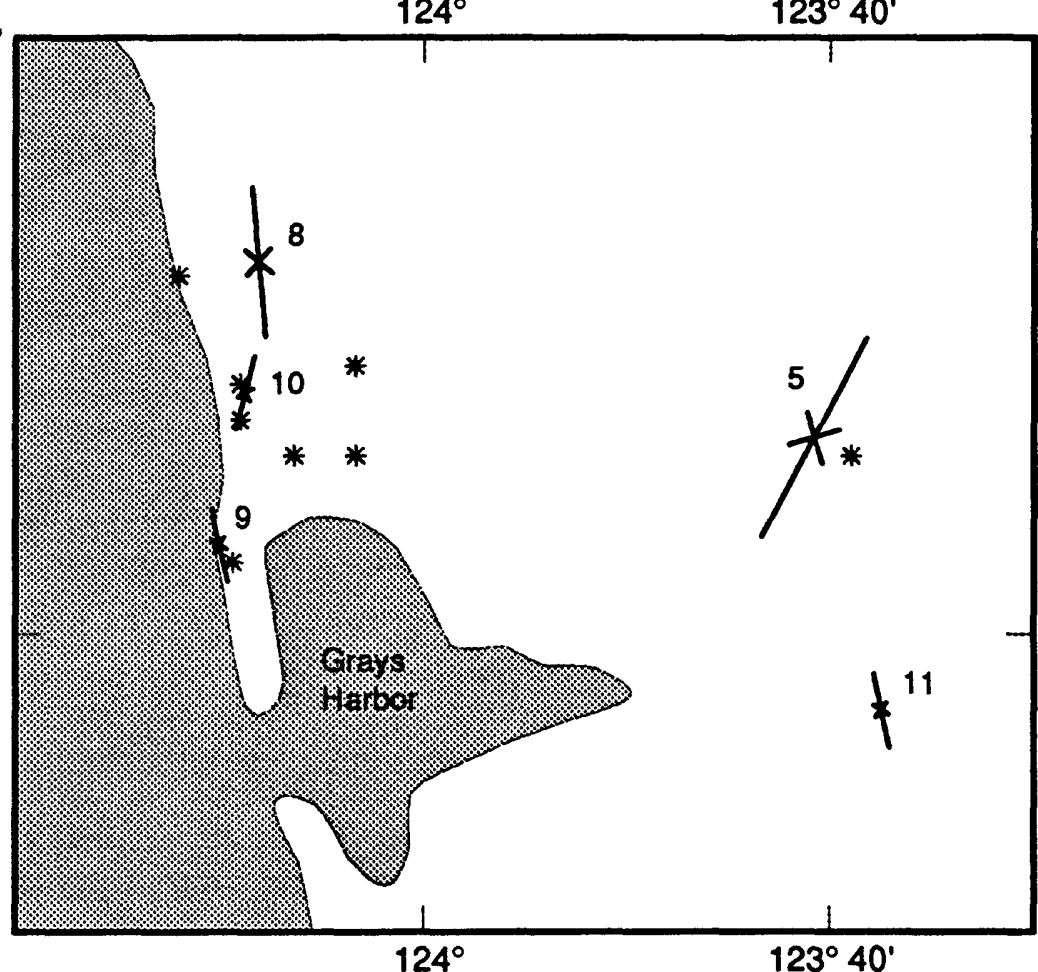

scale 1:900,000

mercator projection

Figure 2
10 Gray's Harbor LHA \#1-15

$n=3 \quad r=1$

Shmin $=N 76^{\circ} \mathrm{W} \pm 30^{\circ}$

$\mathrm{SH} \max =\mathrm{N} 14^{\circ} \mathrm{E} \pm 30^{\circ}$

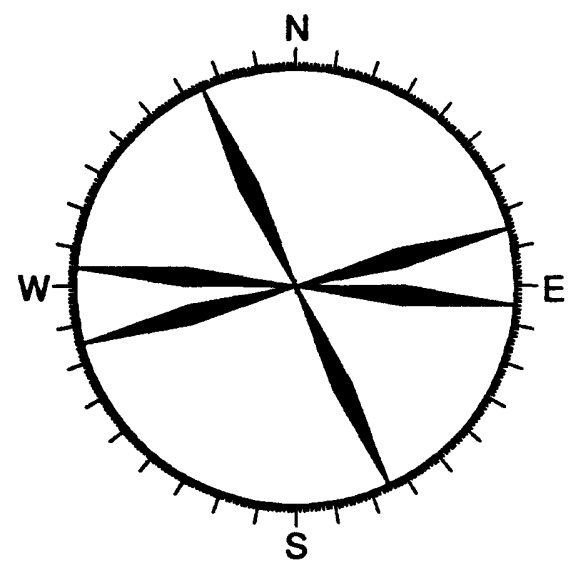

5 Amoco Weyerhauser \#1-29

$n=19 \quad r=8$

Shmin $=N 62^{\circ} \mathrm{W} \pm 7^{\circ}$

$47^{\circ} 20^{\prime}$

$\mathrm{SHmax}=\mathrm{N} 28^{\circ} \mathrm{E} \pm 7^{\circ}$

$47^{\circ}$

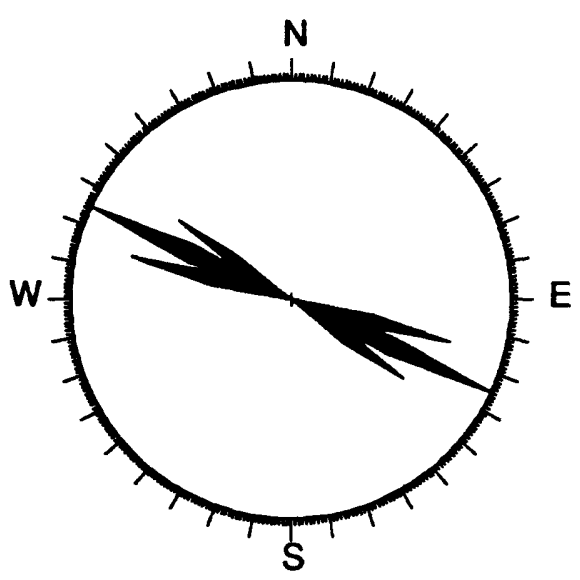

11 Montesano \#1-X

$n=5 \quad r=2$

Shmin $=N 77^{\circ} \mathrm{E} \pm 8^{\circ}$

SHmax $=N 167^{\circ} \mathrm{E} \pm 8^{\circ}$

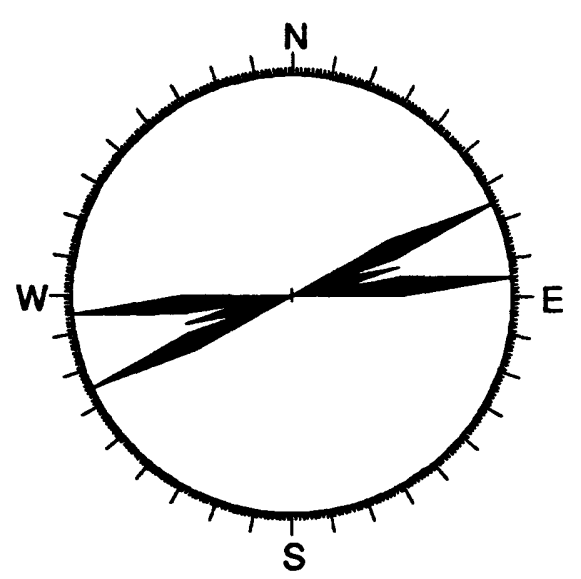


Whidbey \#1 shallow

$n=5 \quad r=2$

Shmin $=N 11^{\circ} \mathrm{E} \pm 25^{\circ}$

$\mathrm{SH}$ max $=\mathrm{N} 101^{\circ} \mathrm{E} \pm 25^{\circ}$
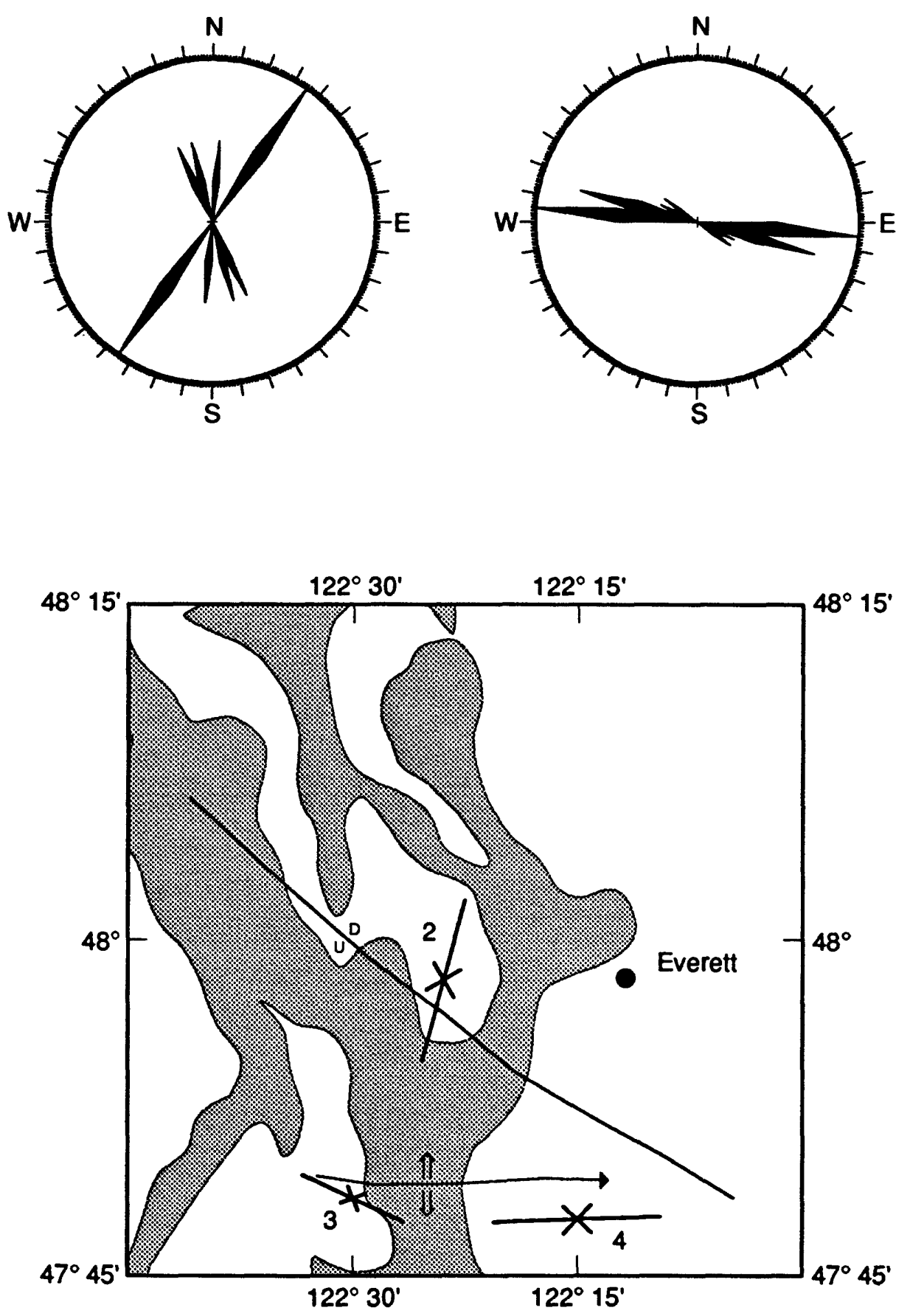

scale 1:900,000

mercator projection

Figure 3

2 Whidbey \#1 deep

$n=9 \quad r=4$

Shmin $=N 75^{\circ} \mathrm{W} \pm 10^{\circ}$

$\mathrm{SHmax}=\mathrm{N} 15^{\circ} \mathrm{E} \pm 10^{\circ}$

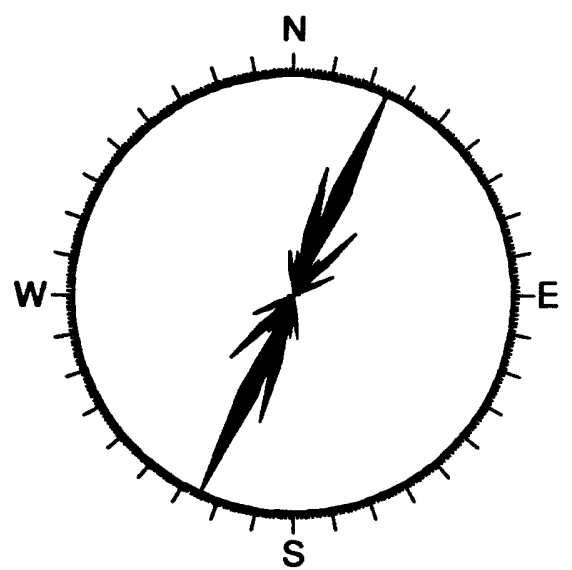

Schroeder \#1 shallow $n=9 \quad r=6$

Shmin $=N 56^{\circ} E \pm 13^{\circ}$

$S H \max =N 146^{\circ} \mathrm{E} \pm 13^{\circ}$

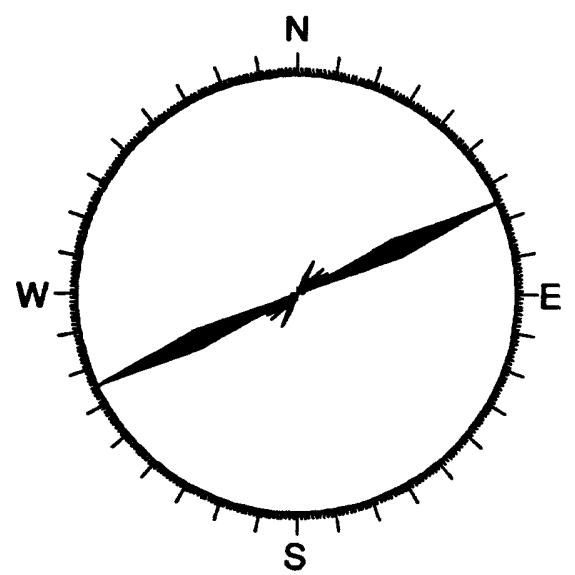

4 Schroeder \#1 deep

$n=13 \quad r=5$

Shmin $=N 1^{\circ} \mathrm{E} \pm 15^{\circ}$

SHmax $=N 89^{\circ} \mathrm{E} \pm 15^{\circ}$

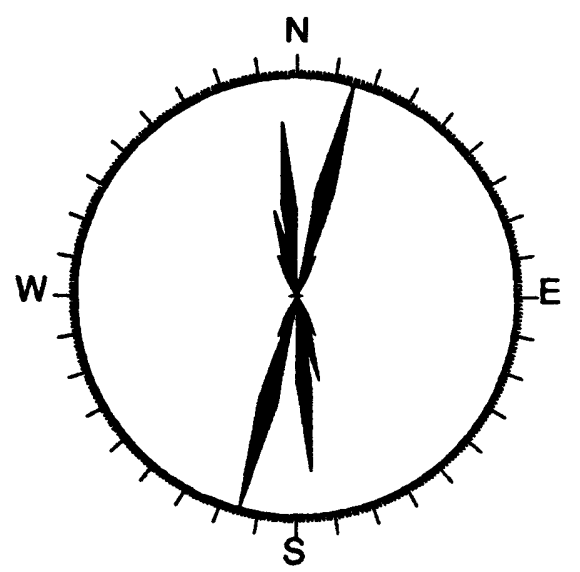



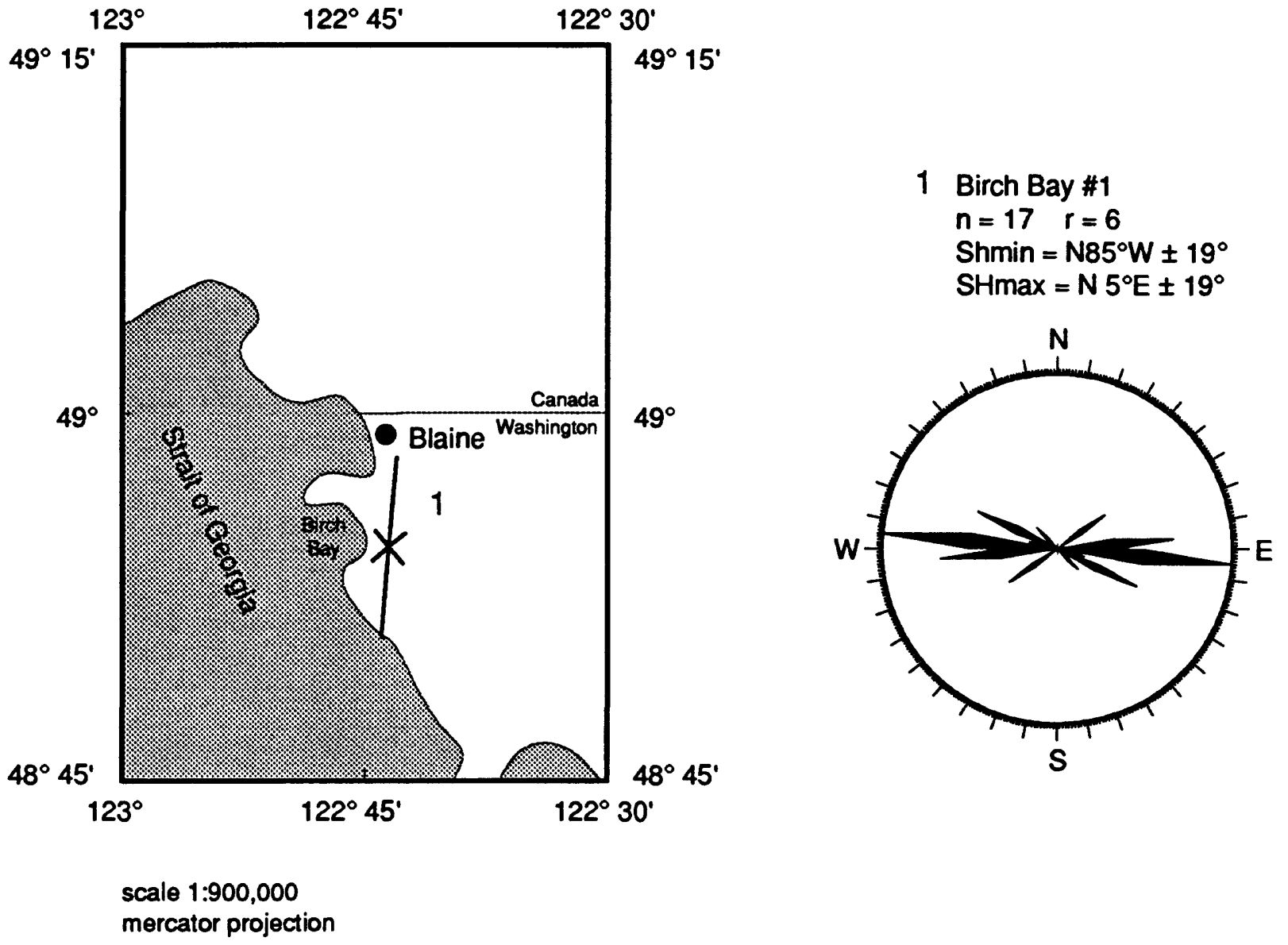

mercator projection

Figure 4 


$$
\begin{aligned}
& 6 \text { Shearing \#1 } \\
& n=4 \quad r=2 \\
& \text { Shmin }=N 20^{\circ} E \pm 7^{\circ} \\
& \text { SHmax }=N 110^{\circ} E \pm 7^{\circ}
\end{aligned}
$$

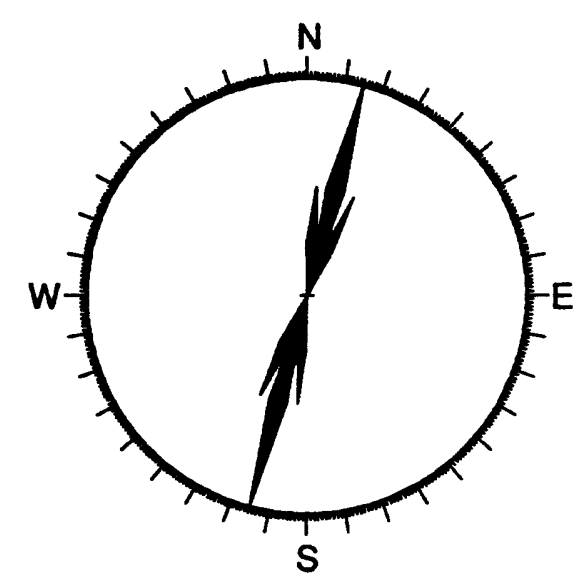

7 State \#1-30

$n=4 \quad r=2$

$\mathrm{Shmin}=\mathrm{N} 65^{\circ} \mathrm{E} \pm 9^{\circ}$

$\mathrm{SH}$ max $=\mathrm{N} 155^{\circ} \mathrm{E} \pm 9^{\circ}$

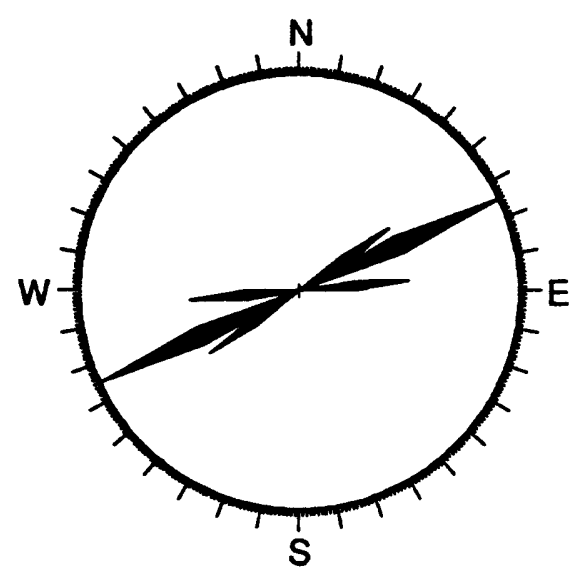

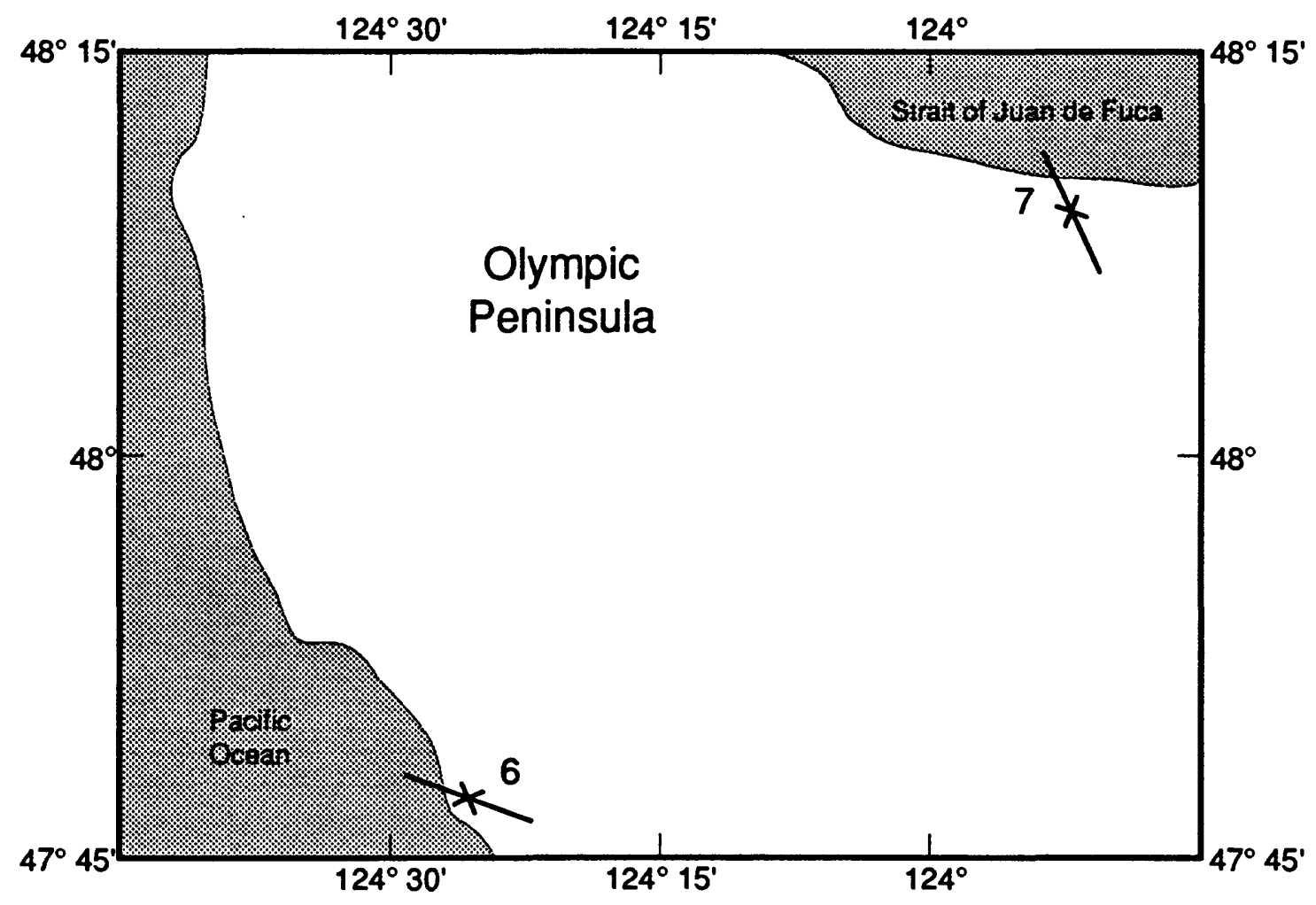

1:900,000

mercator projection

Figure 5 

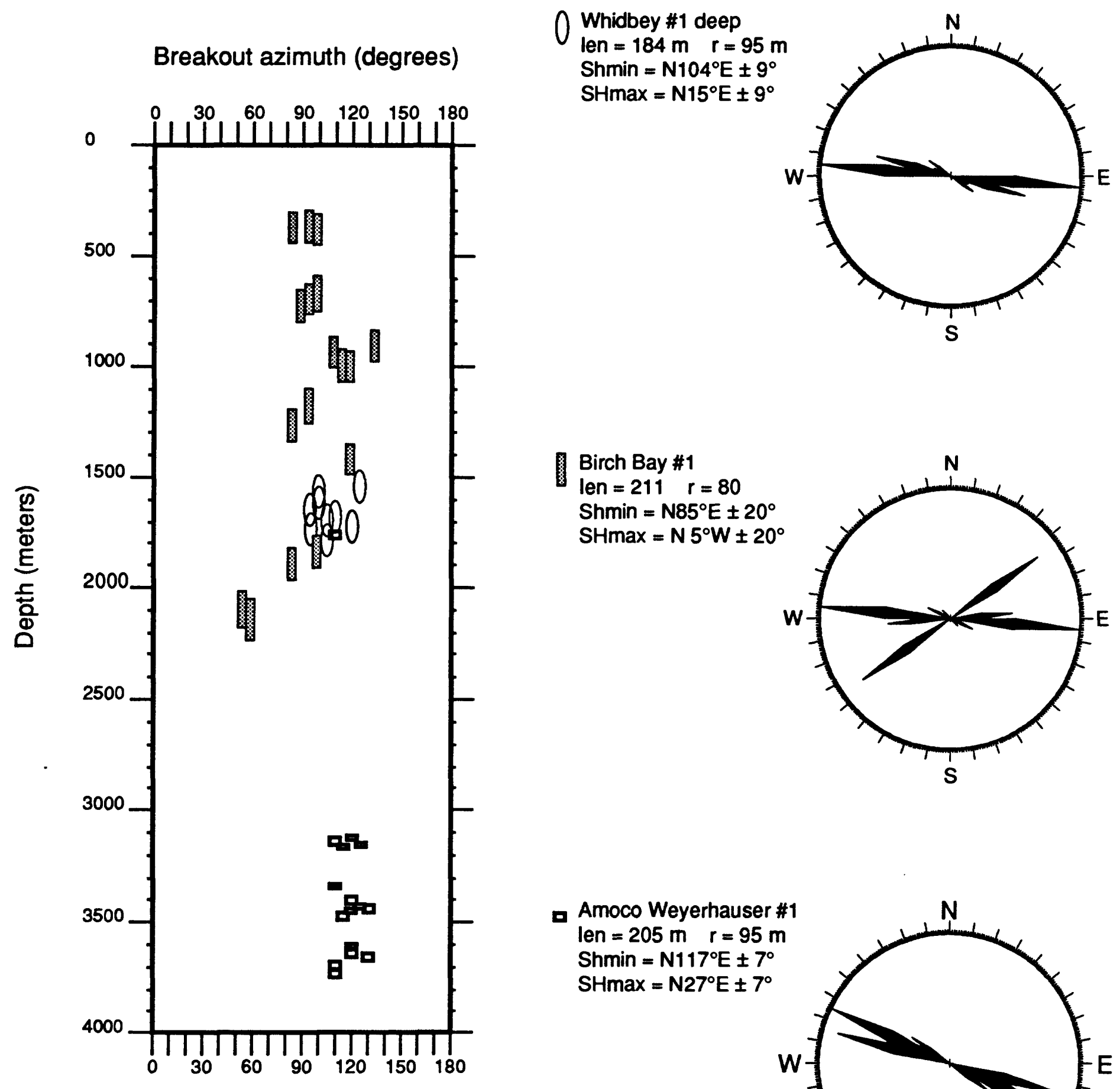

Birch Bay \#1

len $=211 \quad r=80$

Shmin $=N 85^{\circ} E \pm 20^{\circ}$

$\mathrm{SHmax}=\mathrm{N} 5^{\circ} \mathbf{W} \pm 20^{\circ}$

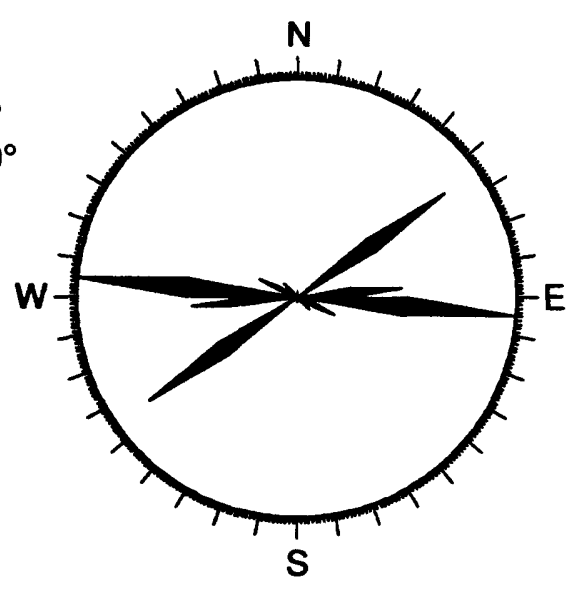

- Amoco Weyerhauser \#1

len $=205 \mathrm{~m} \quad r=95 \mathrm{~m}$

Shmin $=N 117^{\circ} \mathrm{E} \pm 7^{\circ}$

$\mathrm{SH}$ max $=\mathrm{N} 27^{\circ} \mathrm{E} \pm 7^{\circ}$

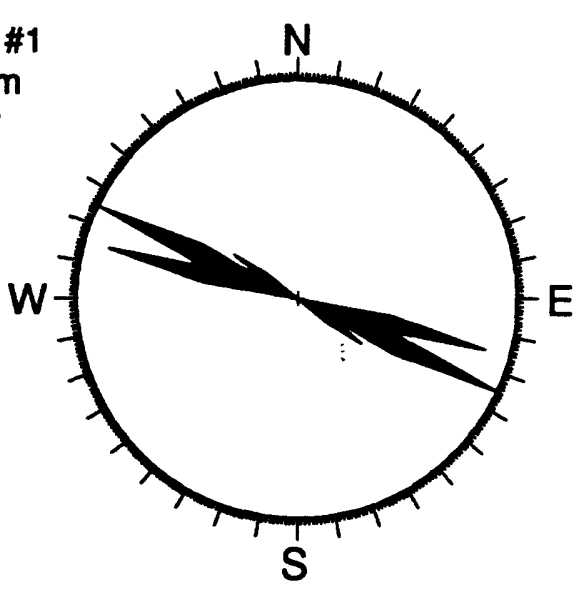

Figure 6 
Breakout azimuth (degrees)

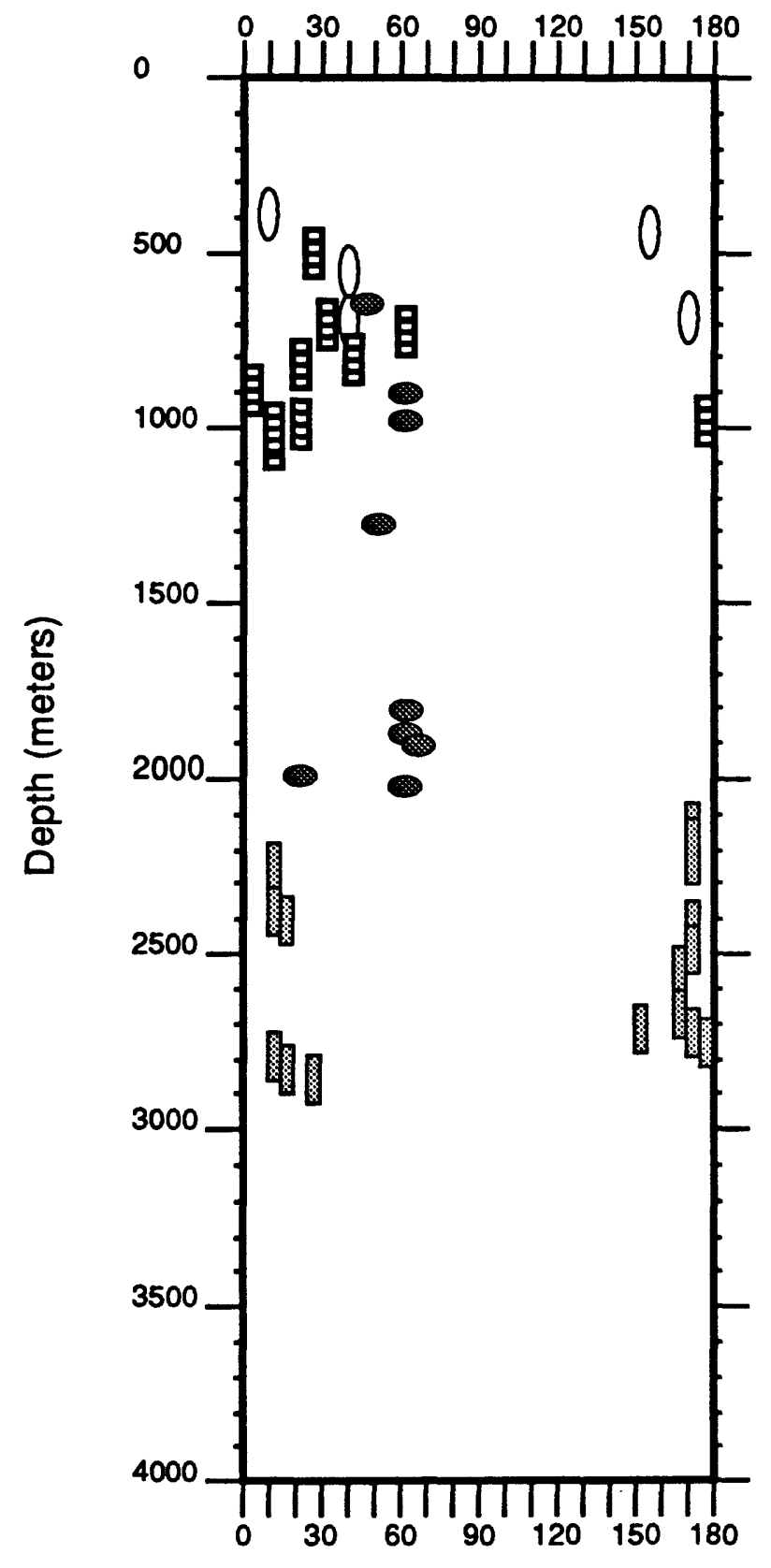

Figure 7

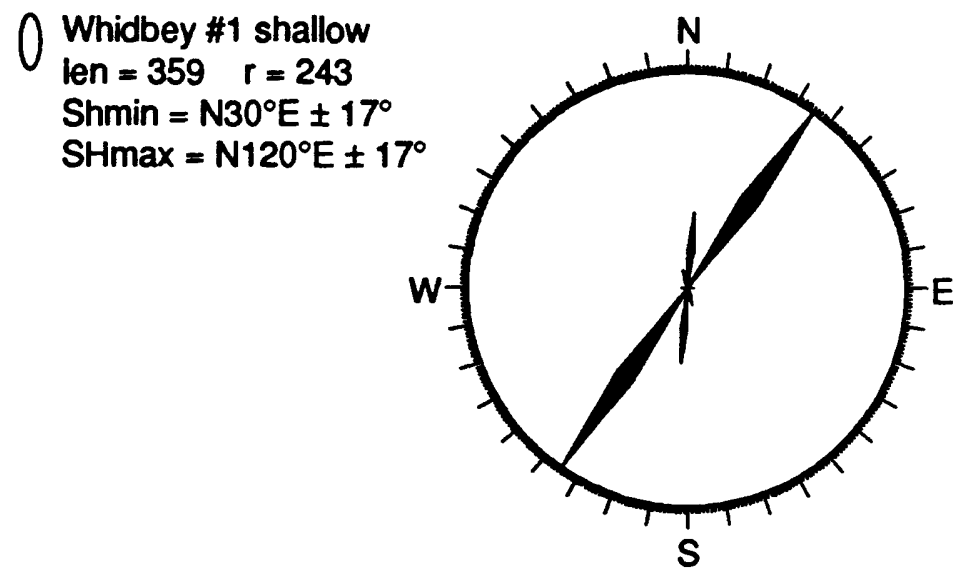

Schroeder \#1 shallow len $=153 \quad r=132$ Shmin $=N 60^{\circ} \mathrm{E} \pm 9^{\circ}$ $\mathrm{SHmax}=\mathrm{N} 149^{\circ} \mathrm{E} \pm 9^{\circ}$

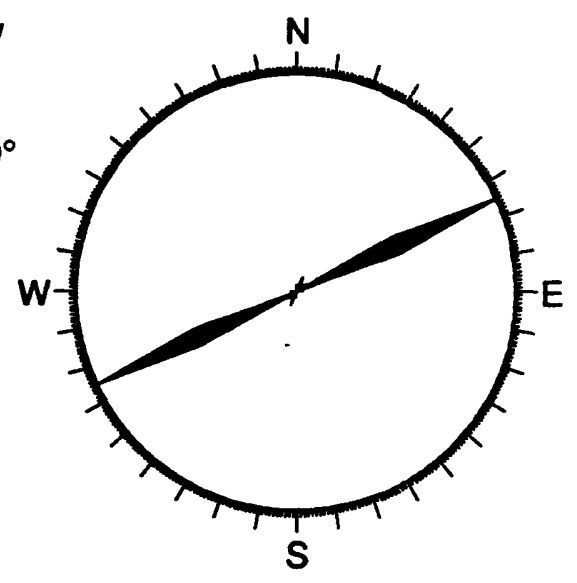

Schroeder \#1 deep len $=465 \quad r=189$ Shmin $=N 2^{\circ} E \pm 13^{\circ}$ $\mathrm{SHmax}=\mathrm{N} 88^{\circ} \mathrm{E} \pm 13^{\circ}$

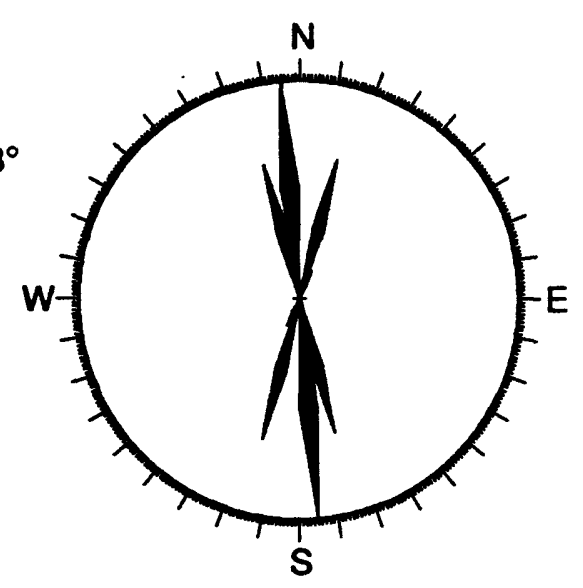

目 Kingston \#1

len $=560 \quad r=286$

Shmin $=$ N27 $E \pm 12^{\circ}$

$S H \max =\mathrm{N} 117^{\circ} \mathrm{E} \pm 12^{\circ}$

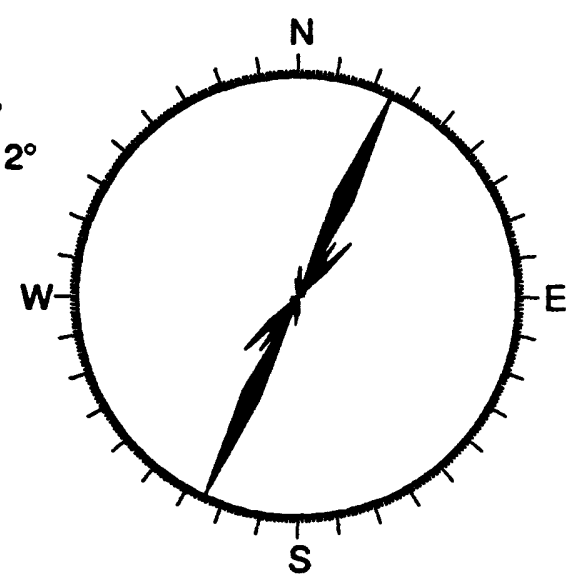




\section{APPENDIX 1}

Table A-1: Status and availability of logs for all wells drilled in Washington state after 1970.

Table A-2: Summary of wellbore breakout analysis. 


\section{TABLE A-1: WASHINGTON STATE PETROLEUM WELLS completed in 1970 or later}

\begin{tabular}{|c|c|c|c|c|}
\hline COUNTY & $\begin{array}{l}\text { WELL } \\
\text { API number } \\
\text { Company }\end{array}$ & $\begin{array}{l}\text { TOTAL } \\
\text { DEPTH } \\
\text { (m) }\end{array}$ & $\begin{array}{c}\text { YEAR } \\
\text { COMPLETED }\end{array}$ & STATUS \\
\hline Benton & $\begin{array}{c}\text { Moon \#1 } \\
\text { 046-005-00035 } \\
\text { Columbia Hydrocarbon }\end{array}$ & 501 & 1982 & Dip log not run \\
\hline \multirow[t]{4}{*}{ Clallum } & $\begin{array}{c}\text { Soleduck \#1 } \\
\text { 046-009-00048 } \\
\text { Eastern Petroleum }\end{array}$ & 472 & 1973 & $\begin{array}{l}\text { Company out of business } \\
\text { or unknown }\end{array}$ \\
\hline & $\begin{array}{l}\text { Sniffer-Forks \#1 } \\
046-009-00049 \\
\text { Eastern Petroleum }\end{array}$ & 943 & 1973 & $\begin{array}{l}\text { Company out of business } \\
\text { or unknown }\end{array}$ \\
\hline & $\begin{array}{c}\text { State \#1 } \\
\text { 046-009-00050 } \\
\text { Fairview Oil \& Gas }\end{array}$ & 2182 & 1982 & Dip log not run \\
\hline & $\begin{array}{c}\text { State \#1-30 } \\
\text { 046-009-00051 } \\
\text { Twin River Oil \& Gas Inc. }\end{array}$ & 2012 & 1986 & Logs acquired \\
\hline \multirow[t]{2}{*}{ Grant } & $\begin{array}{c}\text { Moses Lake \#1A } \\
\text { 046-025-00005 } \\
\text { Snowbird Resources Ltd. }\end{array}$ & 2125 & 1981 & $\begin{array}{l}\text { Company out of business } \\
\text { or unknown }\end{array}$ \\
\hline & $\begin{array}{l}\text { BN \#1-9 } \\
\text { 046-025-00006 } \\
\text { Shell Oil Co. }\end{array}$ & 5339 & 1984 & $\begin{array}{l}\text { Logs requested, } \\
\text { but not available }\end{array}$ \\
\hline \multirow[t]{5}{*}{ Grays Harbor } & $\begin{array}{l}\text { Hogan \#1-13 } \\
\text { 046-027-00106 } \\
\text { Shell Oil Co. }\end{array}$ & 891 & 1970 & 3-arm dip \\
\hline & $\begin{array}{l}\text { Hogan \#1-8 } \\
\text { 046-027-00107 } \\
\text { Shell Oil Co. }\end{array}$ & 425 & 1970 & Logs acquired \\
\hline & $\begin{array}{l}\text { Grays Harbor \#1-11 } \\
\text { 046-027-00110 } \\
\text { Shell Oil Co. }\end{array}$ & 988 & 1970 & $\begin{array}{l}\text { Logs requested, } \\
\text { but not available }\end{array}$ \\
\hline & $\begin{array}{l}\text { irays Harbor LHA \#1-15 } \\
\text { 046-027-00111 } \\
\text { Shell Oil Co. }\end{array}$ & 619 & 1970 & Logs aquired \\
\hline & $\begin{array}{l}\text { Sampson Johns \#1-15 } \\
\text { 046-027-00113 } \\
\text { Shell Oil Co. }\end{array}$ & 852 & 1970 & Logs acquired \\
\hline
\end{tabular}




\begin{tabular}{|c|c|c|c|c|}
\hline COUNTY & $\begin{array}{l}\text { WELL } \\
\text { API number } \\
\text { Company }\end{array}$ & $\begin{array}{l}\text { TOTAL } \\
\text { DEPTH } \\
(\mathrm{m})\end{array}$ & $\begin{array}{c}\text { YEAR } \\
\text { COMPLETED }\end{array}$ & STATUS \\
\hline \multirow[t]{12}{*}{ Grays Harbor } & $\begin{array}{l}\text { McCleave \#1-33 } \\
\text { 046-027-00115 } \\
\text { Shell Oil Co. }\end{array}$ & 410 & 1970 & Logs acquired \\
\hline & $\begin{array}{l}\text { Minard \#1-34 } \\
\text { 046-027-00116 } \\
\text { Shell Oil Co. }\end{array}$ & 1402 & 1970 & Logs acquired \\
\hline & $\begin{array}{c}\text { Sampson Johns \#2-15 } \\
\text { 046-027-00117 } \\
\text { Shell Oil Co. }\end{array}$ & 728 & 1970 & Logs acquired \\
\hline & $\begin{array}{l}\text { Trambitas \#1-28 } \\
\text { 046-027-00118 } \\
\text { Shell Oil Co. }\end{array}$ & 951 & 1970 & Logs acquired \\
\hline & $\begin{array}{c}\text { Ocean City Land Co. } \\
\text { et al \#1-14 } \\
046-027-00120 \\
\text { Shell Oil Co. }\end{array}$ & 1301 & 1970 & Logs acquired \\
\hline & $\begin{array}{c}\text { Grays Harbor \#1-35 } \\
\text { 046-027-00121 } \\
\text { Shell Oil Co. }\end{array}$ & 770 & 1970 & Logs acquired \\
\hline & $\begin{array}{c}\text { Luse \#1-23 } \\
046-027-00122 \\
\text { Shell Oil Co. }\end{array}$ & 1098 & 1970 & Logs acquired \\
\hline & $\begin{array}{c}\text { M.A. Baker \#1-30 } \\
046-027-00123 \\
\text { evelopmental Associates, Inc. }\end{array}$ & 1280 & 1970 & $\begin{array}{l}\text { Company out of business } \\
\text { or unknown }\end{array}$ \\
\hline & $\begin{array}{c}\text { Carlisle \#1-23 } \\
\text { 046-027-00124 } \\
\text { evelopmental Associates, Inc. }\end{array}$ & 1250 & 1970 & Logs acquired \\
\hline & $\begin{array}{c}\text { Grays Harbor Co. \#35-1 } \\
046-027-00125 \\
\text { El Paso Products Co. }\end{array}$ & 760 & 1970 & $\begin{array}{l}\text { Logs requested, } \\
\text { but not available }\end{array}$ \\
\hline & $\begin{array}{l}\text { Montesano \#1-X } \\
046-027-00127 \\
\text { El Paso Products Co. }\end{array}$ & 2112 & 1974 & Logs acquired \\
\hline & $\begin{array}{c}\text { Grays Harbor Co. \#36-1 } \\
\text { 046-027-00128 } \\
\text { El Paso Products Co. }\end{array}$ & 807 & 1974 & $\begin{array}{l}\text { Logs requested, } \\
\text { but not available }\end{array}$ \\
\hline
\end{tabular}




\begin{tabular}{|c|c|c|c|c|}
\hline COUNTY & $\begin{array}{l}\text { WELL } \\
\text { API number } \\
\text { Company }\end{array}$ & $\begin{array}{l}\text { TOTAL } \\
\text { DEPTH } \\
\text { (m) }\end{array}$ & $\begin{array}{c}\text { YEAR } \\
\text { COMPLETEI }\end{array}$ & STATUS \\
\hline \multirow[t]{6}{*}{ Grays Harbor } & $\begin{array}{l}\text { Grays Harbor \#27-1 } \\
\text { 046-027-00129 } \\
\text { El Paso Products Co. }\end{array}$ & 1432 & 1975 & $\begin{array}{l}\text { Logs requested, } \\
\text { but not available }\end{array}$ \\
\hline & $\begin{array}{c}\text { Caldwell Creek \#1 } \\
046-027-00130 \\
\text { El Paso Products Co. }\end{array}$ & 914 & 1975 & Logs acquired \\
\hline & $\begin{array}{c}\text { Grays Harbor Co. \#27-2 } \\
\text { 046-027-00131 } \\
\text { El Paso Products Co. }\end{array}$ & 954 & 1976 & $\begin{array}{l}\text { Logs requested, } \\
\text { but not available }\end{array}$ \\
\hline & $\begin{array}{c}\text { Grays Harbor Co. \#28-1 } \\
\text { 046-027-00129 } \\
\text { El Paso Products Co. }\end{array}$ & 1116 & 1976 & $\begin{array}{l}\text { Logs requested, } \\
\text { but not available }\end{array}$ \\
\hline & $\begin{array}{c}\text { Diane \#1 } \\
\text { 046-027-00133 } \\
\text { Exploration International }\end{array}$ & 337 & 1978 & $\begin{array}{l}\text { Company out of business } \\
\text { or unknown }\end{array}$ \\
\hline & $\begin{array}{c}\text { moco-Weyerhauser \#1-29 } \\
\text { 046-027-00136 } \\
\text { AMOCO Production Co. }\end{array}$ & 93747 & 1985 & Logs acquired \\
\hline Island & $\begin{array}{c}\text { Socal-Whidbey \#1 } \\
\text { 046-029-00004 } \\
\text { Standard Oil Co.of California }\end{array}$ & 2040 & 1972 & Logs acquired \\
\hline \multirow[t]{4}{*}{ Jefferson } & $\begin{array}{c}\text { Lacey \#22-1 } \\
046-031-00026 \\
\text { El Paso Products Co. }\end{array}$ & 1744 & 1975 & $\begin{array}{l}\text { Logs requested, } \\
\text { but not available }\end{array}$ \\
\hline & $\begin{array}{c}\text { Pyramid-Shearing \#1 } \\
046-031-00027 \\
\text { Pyramid Petroleum Inc. }\end{array}$ & 1501 & 1979 & Logs acquired \\
\hline & $\begin{array}{c}\text { Sunburst \#1 } \\
\text { 046-031-00028 } \\
\text { Sunburst Petroleums, Ltd. }\end{array}$ & 2286 & 1981 & $\begin{array}{l}\text { Company out of business } \\
\text { or unknown }\end{array}$ \\
\hline & $\begin{array}{c}\text { Black Diamond \#4-13 } \\
046-031-00028 \\
\text { Voyager Petroleums }\end{array}$ & 2216 & 1983 & $\begin{array}{l}\text { Company out of business } \\
\text { or unknown }\end{array}$ \\
\hline \multirow[t]{2}{*}{ King } & $\begin{array}{c}\text { WC-83-2 } \\
\text { 046-033-00028 } \\
\text { AMOCO Production Co. }\end{array}$ & 847 & 1983 & Dip log not run \\
\hline & $\begin{array}{c}\text { WC-83-1 } \\
\text { 046-033-00029 } \\
\text { MOCO Production Co. }\end{array}$ & 457 & 1983 & Dip log not run \\
\hline
\end{tabular}




\begin{tabular}{|c|c|c|c|}
\hline COUNTY & $\begin{array}{l}\text { WELL } \\
\text { API number } \\
\text { Company }\end{array}$ & $\begin{array}{l}\text { TOTAL } \\
\text { DEPTH } \\
(\mathrm{m})\end{array}$ & $\begin{array}{c}\text { YEAR } \\
\text { COMPLETED }\end{array}$ \\
\hline
\end{tabular}

\section{King}

Kitsap

\section{WC- $83-10$}

046-033-00030

AMOCO Production Co.

WC-83-14

046-033-00033

AMOCO Production Co.

$$
\text { WC-83-17 }
$$

046-033-00037

AMOCO Production Co.

WC-83-21

046-033-00041

AMOCO Production Co.

Kingston \#1

046-035-00010

Mobil Oil Co.

Pope \& Talbot \#18-1

046-035-00011

Union Oil Co.

Kittitas Yakima Mineral Co. \#2-33 1707

046-037-00007

Shell Oil Co.

Lewis Forest Strat Test \#1 676

046-041-00144

Northwest Pipeline Co.

Forest Strat Test \#2
046-041-00145

Northwest Pipeline Co.

Ethel Strat Test \#1

046-041-00146

Northwest Pipeline Co.

Forest Strat Test \#3 752

046-041-00149

Northwest Pipeline Co.

Forest Strat Test \#5 046-041-00150

Northwest Pipeline Co.

WC-83-5

046-041-00158

Amoco Production Co.
346

1984

Dip log not run

534

529

462

1984

Dip log not run

2636

1972

Logs acquired

1972

3-arm dip log

1982

Logs requested, but not available

1975

Logs requested, but not available

1975

Logs requested, but not available

487

1975

Logs requested, but not available

1975

Logs requested, but not available

711

1975

Logs requested, but not available

609

1983
Dip log not run 


\begin{tabular}{|c|c|c|c|c|}
\hline COUNTY & $\begin{array}{l}\text { WELL } \\
\text { API number } \\
\text { Company }\end{array}$ & $\begin{array}{l}\text { TOTAL } \\
\text { DEPTH } \\
(\mathrm{m})\end{array}$ & $\begin{array}{c}\text { YEAR } \\
\text { COMPLETED }\end{array}$ & STATUS \\
\hline Mason & $\begin{array}{l}\text { Weyerhauser \#C-1 } \\
\text { 046-045-00006 } \\
\text { Amoco Production Co. }\end{array}$ & 763 & 1985 & $\begin{array}{l}\text { Logs requested, } \\
\text { but not available }\end{array}$ \\
\hline \multirow[t]{3}{*}{ Pierce } & $\begin{array}{c}\text { Orting \#2 } \\
\text { 046-053-00012 } \\
\text { Concept Resources }\end{array}$ & 614 & 1976 & $\begin{array}{l}\text { Company out of business } \\
\text { or unknown }\end{array}$ \\
\hline & $\begin{array}{c}\text { WC-83-6 } \\
\text { 046-053-00016 } \\
\text { Amoco Production Co. }\end{array}$ & 609 & 1984 & Dip log not run \\
\hline & $\begin{array}{c}\text { WC-83-27 } \\
\text { 046-053-00019 } \\
\text { Amoco Production Co. }\end{array}$ & 610 & 1984 & Dip log not run \\
\hline \multirow[t]{8}{*}{ King } & $\begin{array}{c}\text { WC-83-29 } \\
\text { 046-053-00023 } \\
\text { Amoco Production Co. }\end{array}$ & 312 & 1984 & Dip log not run \\
\hline & $\begin{array}{c}\text { Kerryn BN \#34-11 } \\
\text { 046-053-00029 } \\
\text { L.B. Petroleum }\end{array}$ & 1485 & 1986 & $\begin{array}{l}\text { Logs requested, } \\
\text { but not available }\end{array}$ \\
\hline & $\begin{array}{c}\text { Wilexco-Carbonado \#1-17 } \\
\text { 046-053-00035 } \\
\text { Wilexco, Inc. }\end{array}$ & 417 & 1986 & $\begin{array}{l}\text { Company out of business } \\
\text { or unknown }\end{array}$ \\
\hline & $\begin{array}{c}\text { Carbon River \#2-20 } \\
\text { 046-053-00042 } \\
\text { Carbon River Energy Partnership }\end{array}$ & $1829 ?$ & 1986 & $\begin{array}{l}\text { Logs requested, } \\
\text { but not available }\end{array}$ \\
\hline & $\begin{array}{c}\text { Carbon River \#3-29 } \\
\text { 046-053-00043 } \\
\text { Carbon River Energy Partnership }\end{array}$ & $1829 ?$ & 1986 & $\begin{array}{l}\text { Logs requested, } \\
\text { but not available }\end{array}$ \\
\hline & $\begin{array}{c}\text { Carbon River \#5-20 } \\
\text { 046-053-00044 } \\
\text { Carbon River Energy Partnership }\end{array}$ & $1829 ?$ & 1986 & $\begin{array}{l}\text { Logs requested, } \\
\text { but not available }\end{array}$ \\
\hline & $\begin{array}{c}\text { Carbon River \#4-20 } \\
\text { 046-053-00046 } \\
\text { Carbon River Energy Partnership }\end{array}$ & $1829 ?$ & 1986 & $\begin{array}{l}\text { Logs requested, } \\
\text { but not available }\end{array}$ \\
\hline & $\begin{array}{c}\text { Plum Creek \#23-2 } \\
\text { 046-053-000047 } \\
\text { Meridian Oil \& Gas Inc. }\end{array}$ & 1402 & 1988 & CDP log acquired \\
\hline Snohomish & $\begin{array}{c}\text { Socal-Schroeder \#1 } \\
046-061-00013 \\
\text { Standard Oil Co. of California }\end{array}$ & 2949 & 1988 & Logs acquired \\
\hline
\end{tabular}




\begin{tabular}{ccccc} 
COUNTY & $\begin{array}{c}\text { WELL } \\
\text { API number } \\
\text { Company }\end{array}$ & $\begin{array}{c}\text { TOTAL } \\
\text { DEPTH } \\
(\mathrm{m})\end{array}$ & $\begin{array}{c}\text { YEAR } \\
\text { COMPLETED }\end{array}$ & STATUS \\
\hline Stevens & $\begin{array}{c}\text { Hague \#1 } \\
\text { 046-065-00008 } \\
\text { Sonex Resources Unlimited }\end{array}$ & 427 & 1980 & $\begin{array}{c}\text { Company out of business } \\
\text { or unknown }\end{array}$ \\
Walla Walla & $\begin{array}{c}\text { Darcell-Westem \#1 } \\
\text { 046-071-00003 } \\
\text { Shell Western E\&P Inc. }\end{array}$ & 2608 & 1988 & $\begin{array}{c}\text { Logs requested, } \\
\text { but not available }\end{array}$ \\
Whatcom & $\begin{array}{c}\text { Birch Bay \#1 } \\
\text { 046-073-00095 }\end{array}$ & 2782 & 1988 & Logs acquired \\
& American Hunter Exploration & & &
\end{tabular}




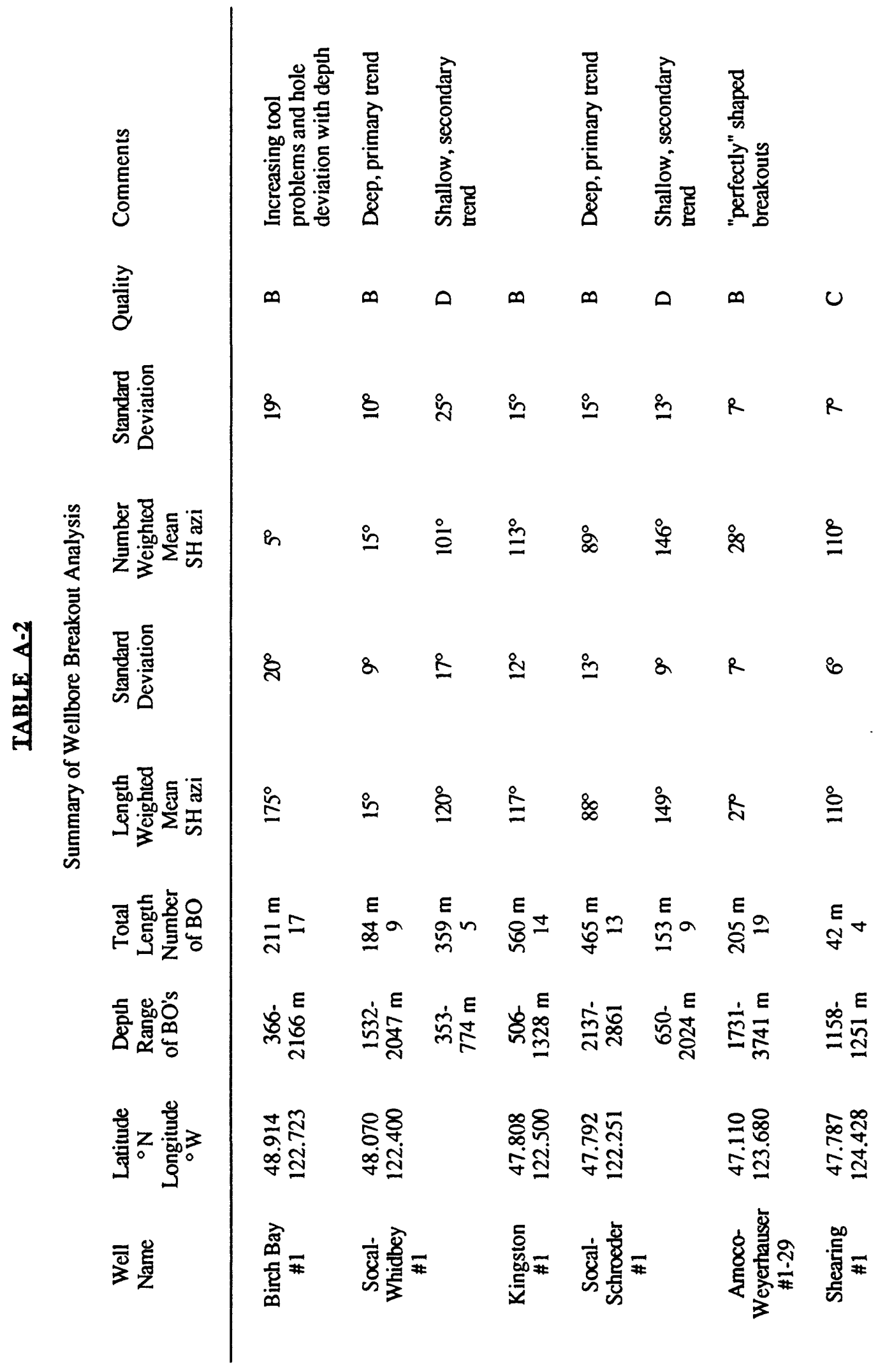




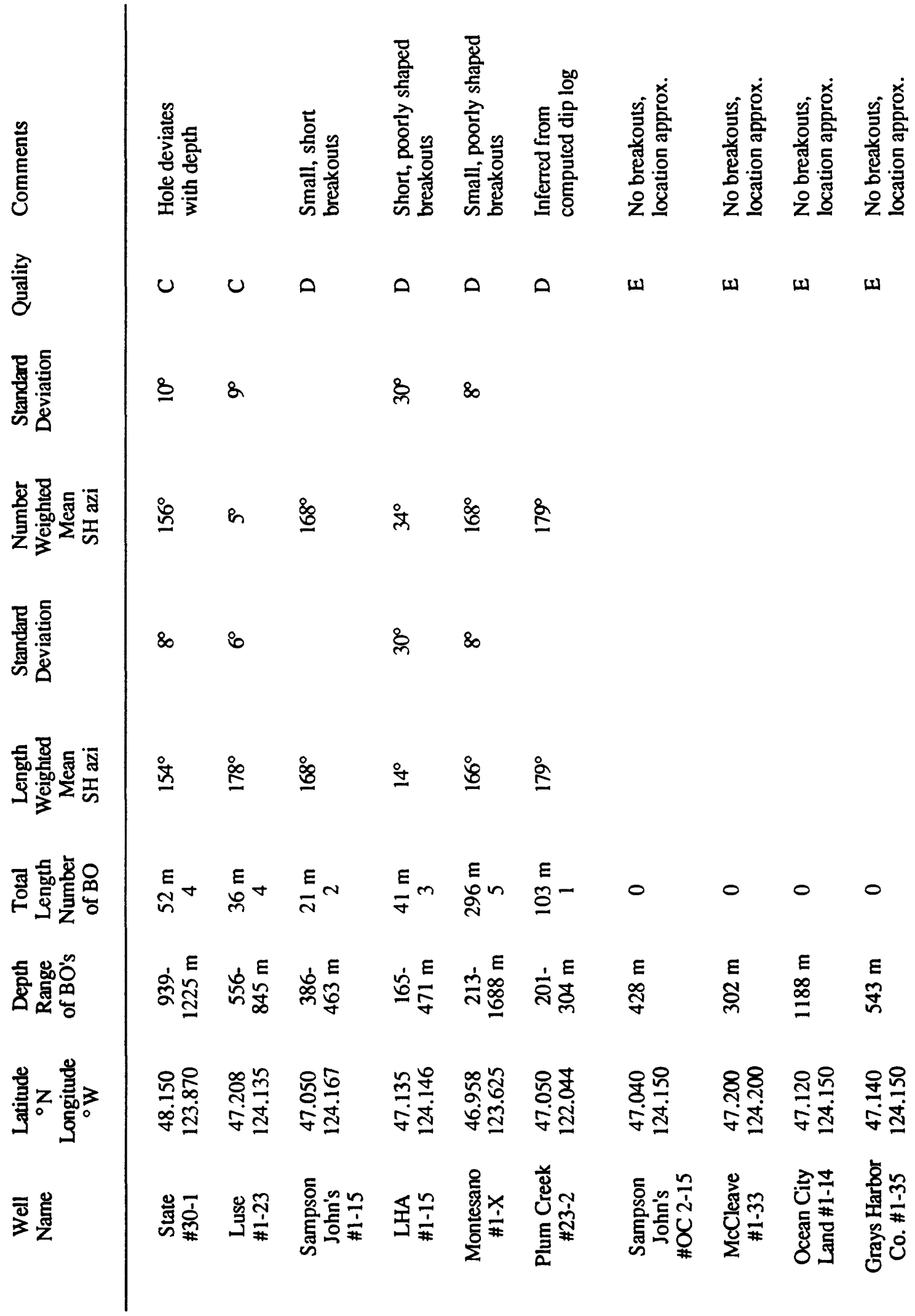




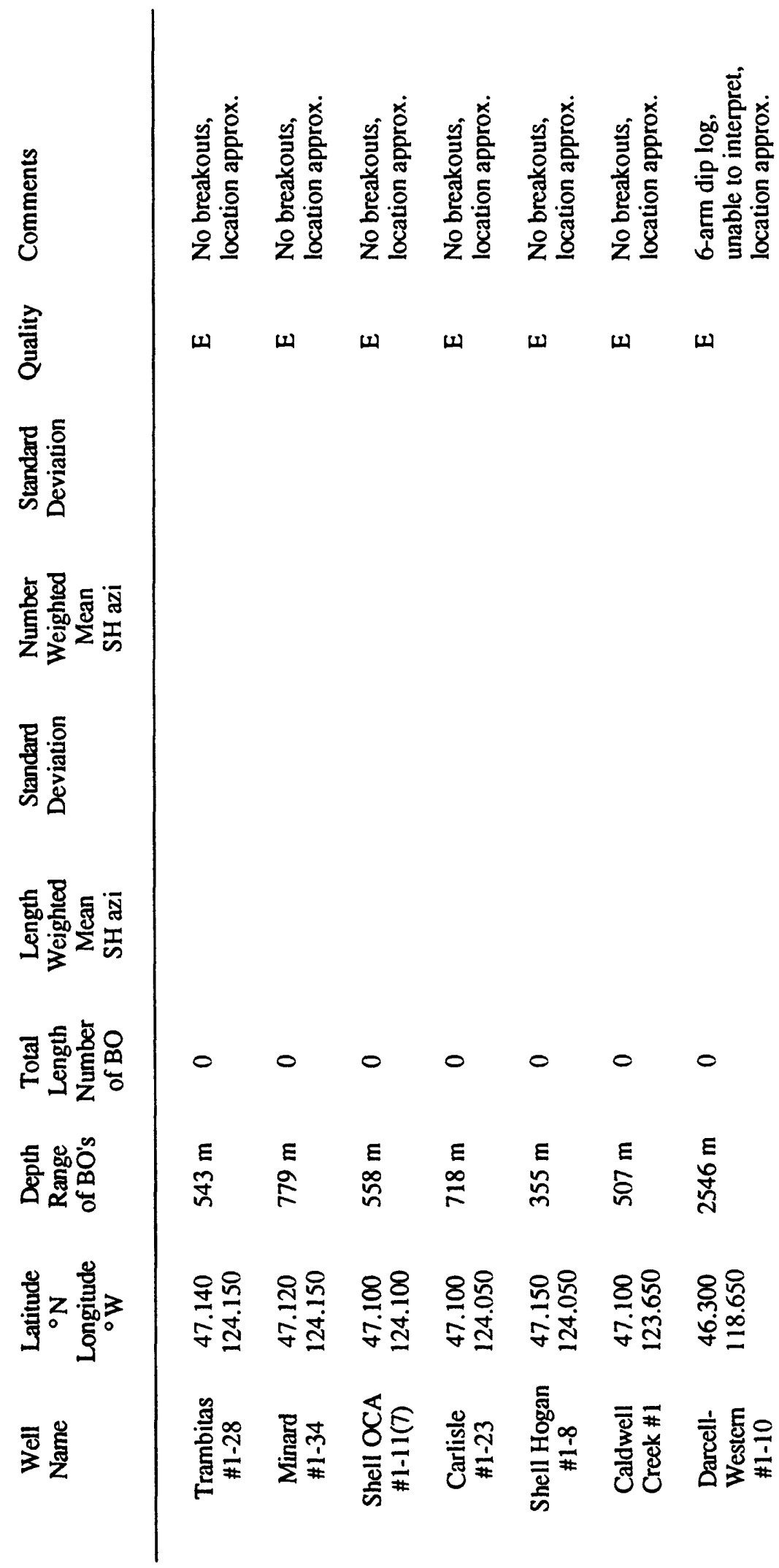




\section{APPENDIX 2}

Details of $\log$ observations for each of 12 wells with wellbore enlargements.

Summary statistical analysis for each of 12 wells with wellbore enlargements. 
WASHINGTON STATE DATA

BIRCH BAY \#1

2 WA294 DECL $=23.0 \quad$ LAT $=48.914$ LON $=-122.723$

WHATCOM CO. , WASHINGTON, AMERICAN HUNTER EXPL.

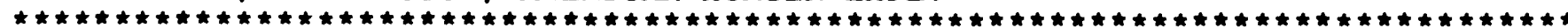

PAD TOP BOT AZ1 RB VD AHD O COMMENTS

01 1202. 1212. 250. 205. 0.5

$01 \quad 1216.1228 .240 .193 .0 .75$

01 1242. 1264.255. 210. 0.75

02 1386. 1460.330. 278. 1.0

01 1464. 1486.310. 260. 1.0

02 1488. 1550.325. 275. 1.0

02 2170. 2270.345. 295. 0.0

012274.2290 .250 .200 .0 .0

2362 . 2422. 155 .

205 .

0.75

2440. 2496. 190.

215 .

1.0

2846. 2888. 90. 115.

AHD $Q$ COMMENTS

45. 2 ONE OF SERIES OF SHRT BO W/IN GOOD ROT

47. 2 DITTO

45. 2 DITTO

52. 2 GOOD ROT ABV, BLW, OK SHAPE

50. 4 WOBBLY TOOL, DOESN'T LOCK IN

50. 4 LOUSY SHAPE; LCSE RB, AHD BELOIT

50. 2 GOOD SHAPE, ROT; NO RB, AHD SO FAKED

50. 2 GOOD SHAPE, ROT; NO RB, AHD SO FAKED

310. 2 GOOD SHAPE, ROT; AHD, RB RTN AT MID

2914. 2970. 130 .

95.

0.0

335. 4 OK SHAPE, SOME ROT THRU, BLW WO ZONE

2970. 2992. 110 .

75.

335. 4 INCL 4 BO'S; PR ROT ABV, GD BLW

3066 . 3080. 355 .

310 .

0.5

35. 2 OK SHAPE, GD ROT ABV, TOOL FLPS BLW

3142 . 3150 . 240 .

200 .

0.75

35. 2 GOOD SHAPE AND ROTATION ABV, BLW

45. 2 GD SHAPE; FLIPS ABV, BLW;

3206.3258 .275 .230 .2 .0

40. 4 V.SHORT; GD SHAPE, ROT; ?LOCKED IN?

3260 . 3282 . 180 .

140 .

0.75

45. 3 PR SHAPE TILL END; GOOD ROT ABV, BLW

01

3284 . 3300.275 .

235.

1.75

3300 . 3370. 250 .

210 .

2.0

40. 1 GOOD SHAPE; TOOL FLIPS ABV, BLW

3390.3400 .250 .

225.

2.0

40. 1 GOOD SHAPE AND ROTATION

40. 4 POOR SHAPE W/ ROTATION THRU

02

3550 . 3560. 160 .

140 .

2.0

25. $3 \mathrm{~V}$ SHORT, GOOD SHAPE AND ROTATION

3562 . 3572 . 190 .

170 .

1.5

20. 3 SHORT; ROT ABV, BLW;

3676.3690 .260 .

240 .

2.0

10. $5 \mathrm{KS}$; AHD WOBBLY

245. 1.8

20. 3 BELOW WO, SHAPE POOR, ROT BLW

5. 2 NUM SHRT BO'S; GOOD SHAPE, ROT

3900.3968 .275 .270 .2 .0

5. 4 POOR SHAPE, SOME TOOL ?OT;

01

4008.4018 .260 .

250 .

2.0

4100.4144 .280 .

270 .

1.5

10. 4 GOOD SHAPE, POOR ROT; LNREAD IZI.

10. 4 POOR SHAPE; GOOD ROT ABV, $B^{\top} W$

4144. 4170. 240. 220. 1.5

20. 2 GOOD SHAPE, ROTATION

4280.4340 .270 .265 .2 .0

5. 35 SHRT SHRP BO'S, GOOD ROT

$4646.4658 \cdot 185.175 \cdot 3.0$

10. 2 SHRT, PEAKY; GOOD ROT; CONS AZI;

10. 3 SHORT, NOT LOCKED IN??

4924. 4936.360. 340. 2.5

20. 4 GD SHP, SOME ROT ABV, STUCK BELOW

290. 3.0

20. 4 R THRU U.SECT; GD R ABV, BLW; PR SHAPE

$\begin{array}{lll}5102.5170 .230 . & 205 . & 3.0 \\ 5352.5366 .280 . & 255 . & 3.5\end{array}$

25. 4 OK SHP, TOOL STICK IN MIDL, PR ROT BLW

25. 4 GD SHP, DOESN'T LOCK IN, GD ROT

5534. 5568. 280. 245. 3.0

35. 4 TOOL STUCK BELOW, OK ROT ABV; GD SHAPE

5590. 5610. 290. 250. 3.0

5950. 5975. 195. 180. 2.5

6004.6040 .165 .150 .3 .0

6114.6126 .35 .25 .3 .0

6202.6230 .330 .320 .3 .5

6350.6400 .360 .345 .4 .0

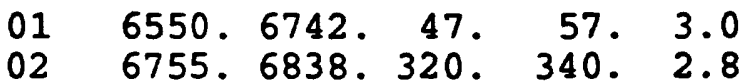

40. 4 TOOL STUCK ABV. GD ROT BLW, PR SHAPE

15. 4 SOME ROT ABV, BLW; SHRT PEAKY

15. 2 GOOD SHAPE, ROTATION

10. 4 GD SHP, ROT ABV, STUCK BLW, HRD 2 READ

10. 2 GD ROT ABV, SOME BLW, PEAKY SHAPE

15. 4 SHRT PEAKY; STUCK BLi:, ROT ABV

6842 . 6920. 210 .

220. 2.5

350. 3 CASING ABV, ROT BLW; $10^{\prime}$ WO IN MID

6968. 7106. 305. 320. 2.0

7550. 7664. 125. 135. 2.5

7712.7770 .40$.

60 .

2.75

7814. 7900. 50 .

65.

2.8

340. 4 GD ROT ABV, BLW; NUM SHRT BO'S, PR SHP

350. 2 GOOD ROT ABV, BLW

345. 2 GOOD ROT, OK SHAPE; TGNEOUS SILL

350. 4 BETW WO ZONES, POOR ROT

8004.8070 .320 . 350. 2.25

340.4 TOOL STUCK, WO ABV N BLW, NO ROT

8074 . 8106. 345 .

15.

2.5

345. 3 WO ABOVE, GOOD ROT BELOW

8110.8170 .310 .

345 .

330. 3 GOOD ROT ABV, NONE BLW; RB FLIPS

330. 3 OK SHAPE, ROT

8302.8390 .330 .20 .5 .5

325. 3 SOME ROT ABV N BLW

310. 3 OK SHAPE, KS ABV N BLW

25. 6.5

300. $4 \mathrm{KS} A B V, B L W$, POOR SHAPE 
WASHINGTON STATE DATA

SOCAL-WHIDBEY \#1
0 WA25
20.0
$48.07 \quad-122.40$

ISLAND CO., WASHINGTON, STANDARD OIL CO. OF CALIFORNIA

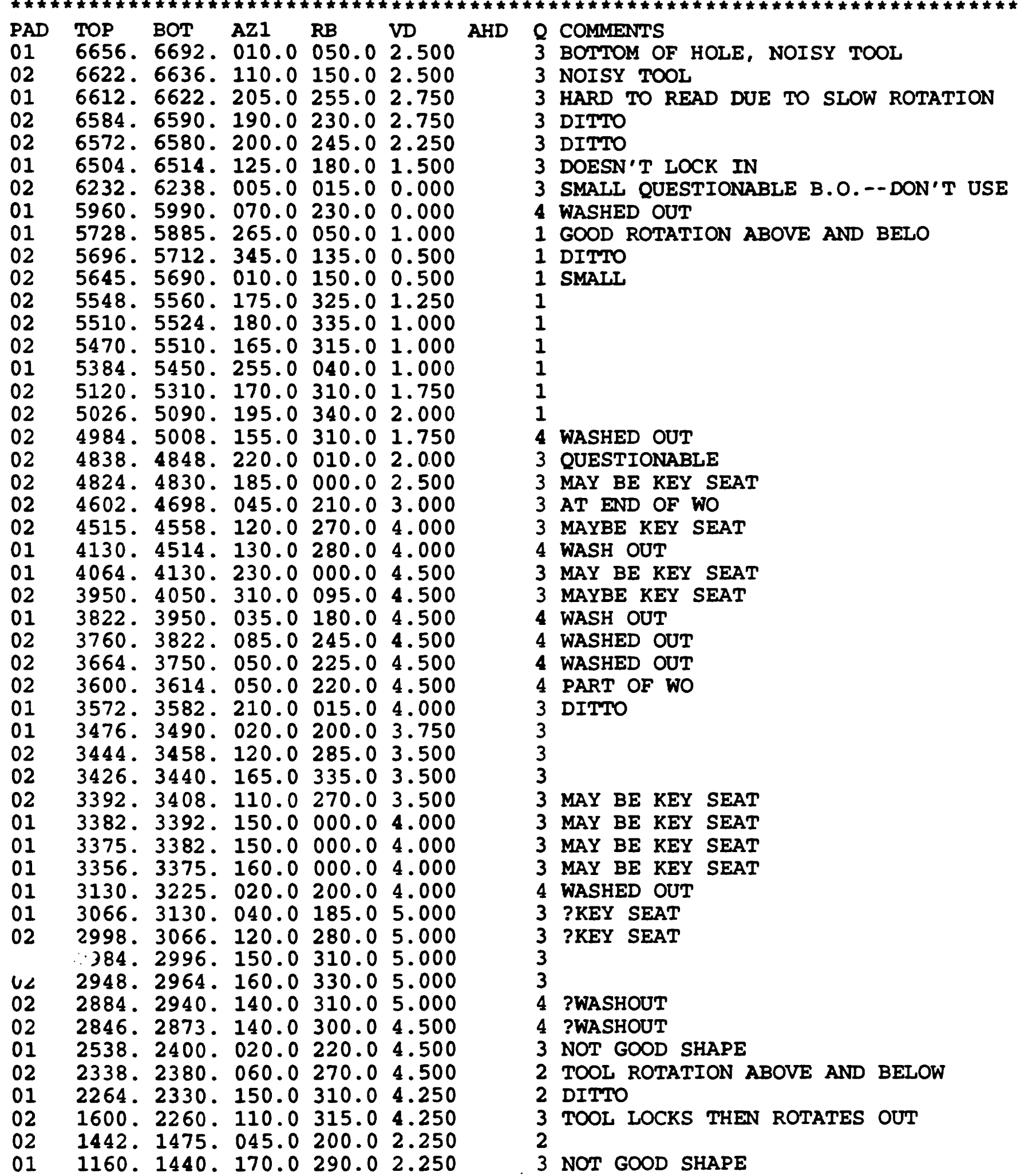


WASHINGTON STATE DATA

SOCAL-WHIDBEY \#1 SHALLOW

$\begin{array}{lllll}0 & \text { WA2 } 82 & 20.0 & 48.07 & -122.40\end{array}$

ISLAND CO., WASHINGTON, STANDARD OIL CO. OF CALIFORNIA

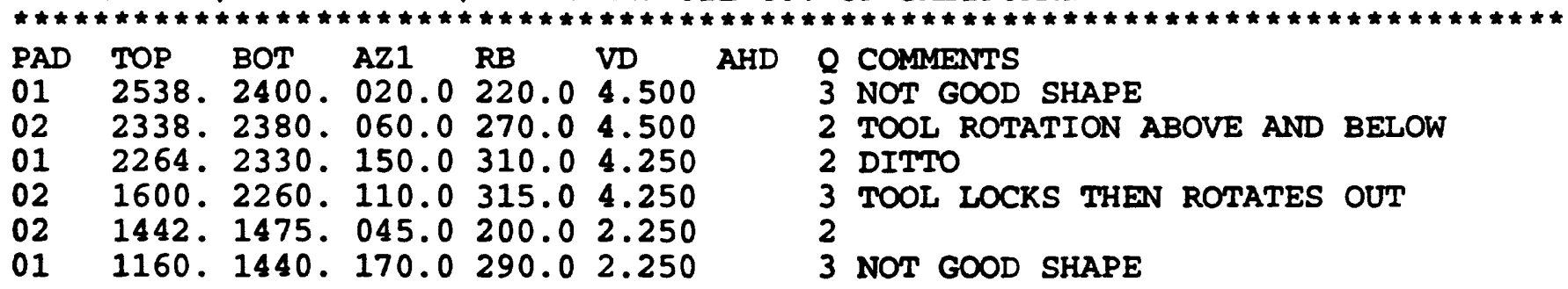

WASHINGTON STATE DATA

KINGSTON 1

$\begin{array}{lllll}0 & \text { WA2 84 } & 22.0 & 47.808 & -122.500\end{array}$

KITSAP CO. , WASHINGTON, MOBIL OIL CO.

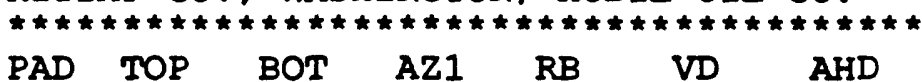

01 5000.5006.130.0 310.0 2.000

$01 \quad 4914.4980 .170 .0350 .02 .000$

024780.4890 .265 .0095 .02 .000

014596.4712 .345 .0180 .02 .000

014310.4358 .350 .0195 .02 .000

$02 \quad 4226.4234 .080 .0300 .02 .000$

02 4206.4216.080.0 300.02.000

$01 \quad 3984.4054 .360 .0210 .02 .000$

013584.3737 .360 .0210 .02 .000

013516.3534 .360 .0210 .02 .000

013434.3510 .335 .0080 .02 .000

$02 \quad 3310.3434 .070 .0290 .02 .000$

$02 \quad 3275.3290 .110 .0340 .02 .000$

013214.3260 .180 .0050 .02 .000

$02 \quad 2910.3214 .290 .0150 .02 .000$

$02 \quad 2670.2706 .310 .0170 .02 .000$

$02 \quad 2370.2650 .280 .0150 .02 .000$

011660.2310 .185 .0125 .02 .000

$Q$ COMMENTS

3 NEVER LOCKS IN

3

4 WASHOUT

3

2 BOTH ARMS > BIT SIZE

2 SMALL

2 SMALL

1

1

1

1

1

2

1

1

2

2 NOISY

1 DEPTH RANGE INFERRED FROM REPEAT SECTIO:

WASHINGTON STATE DATA SOCAL-SCHROEDER \#1
0 WA23
22.0
$47.792-122.251$

SNOHOMISH CO., WASHINGTON, STANDARD OIL CO. OF CALIFORNIA

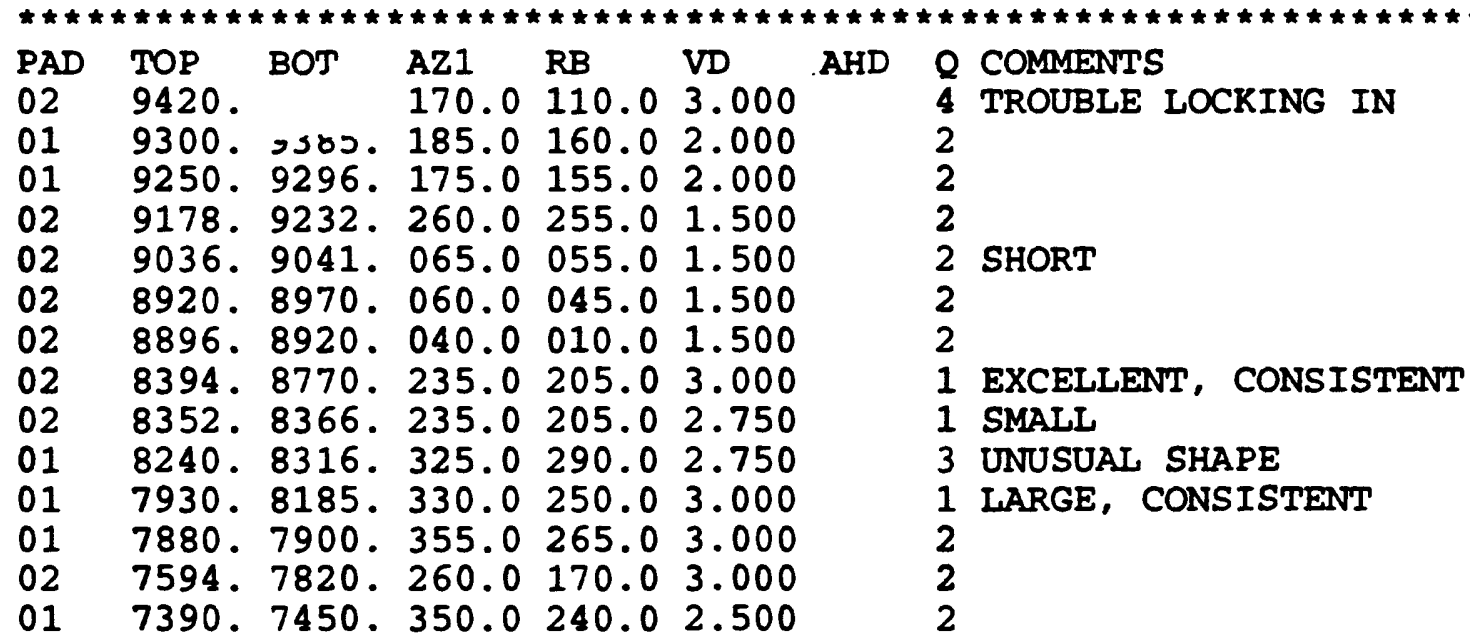


7010.7320.240.0220.02.000

01

02

02

02

02

02

02

02

01

01

02

01

02

01

01

01

01

01

01

01

01

6840.6950 .320 .0220 .02 .000

6550.6640.040.0 320.0 1.000

6520.6550 .090 .0360 .01 .250

6346. 6352. 000.0300 .01 .000

$6252.6274 .135 .0 \quad 060.01 .750$

6176. 6184. 310.0230 .01 .750

5920. 5936. $130.0 \quad 050.01 .750$

5542 . 5620. 320.0100 .01 .000

5130.5240 .310 .0260 .01 .250

4648. 4740. 050.0185 .02 .100

4186. 4210.030.0 270.0 1.000

3334.3950 .280 .0090 .01 .750

3270 . 3330. $260.0 \quad 075.01 .750$

2990 . 3260.310.0 120.0 1.750

2830. 2940.025.0 360.0 1.500

2676. 2830. 030.0350 .01 .500

2650.2676.050.0 350.0 1.500

2240. 2260.065.0280.0 0.500

2160.2186. $040.0280 .0 \quad 0.750$

2134. 2150.025.0 295.0 0.750

1910. 2054.000.0 360.0 1.250

1580.1840.000.0 170.0 1.000
2

3 SERIES OF SMALL, SHARP ENLARGEMENTS, JU 3

3

4 WASHED OUT

3

3 SHORT

3 ROTATING THROUGH

5 KEY SEAT

5 KEY SEAT

5 KEY SEAT

3 SHORT

5 KEY SEAT

4 DOESN'T LOCK IN

3 SIX B.O.'S, APPROX. 20' LONG

5 PROBABLE KEY SEAT

5 PROBABLE KEY SEAT

5 PROBABLE KEY SEAT

5 KEY SEAT

3

3

5 KEY SEAT

5 KEYSEAT

WASHINGTON STATE DATA

SOCAL-SCHROEDER \#1 SHALLOW

$\begin{array}{lllll}0 & \text { WA2 } & 22.0 & .47 .792 & -122.251\end{array}$

SNOHOMISH CO. WASHINGTON, STANDARD OIL CO. OF CALIFORNIA

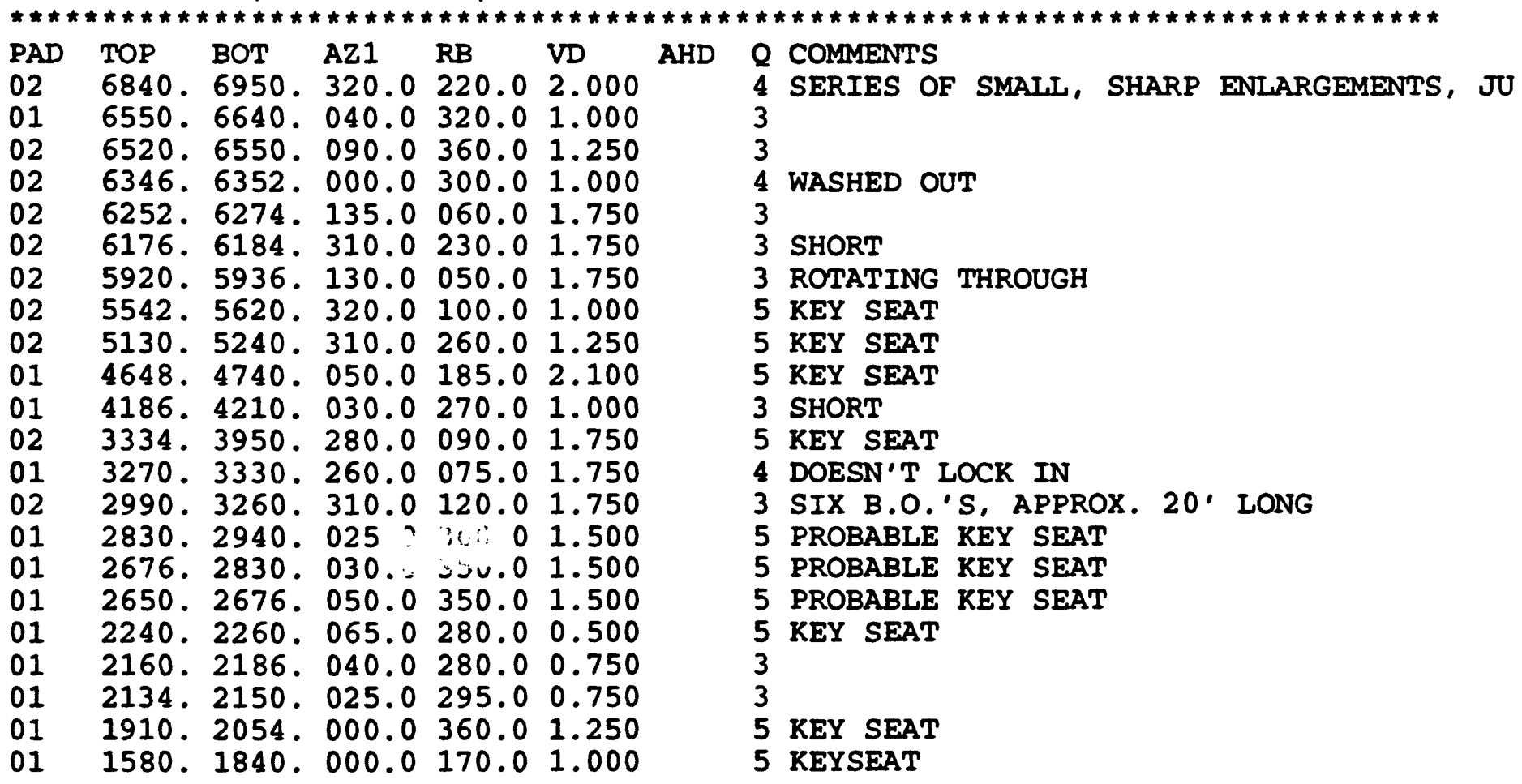


WASHINGTON STATE DATA

AMOCO WEYERHAUSER 1-29

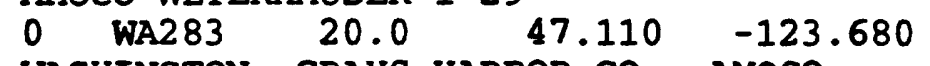

WASHINGTON, GRAYS HARBOR CO., AMOCO

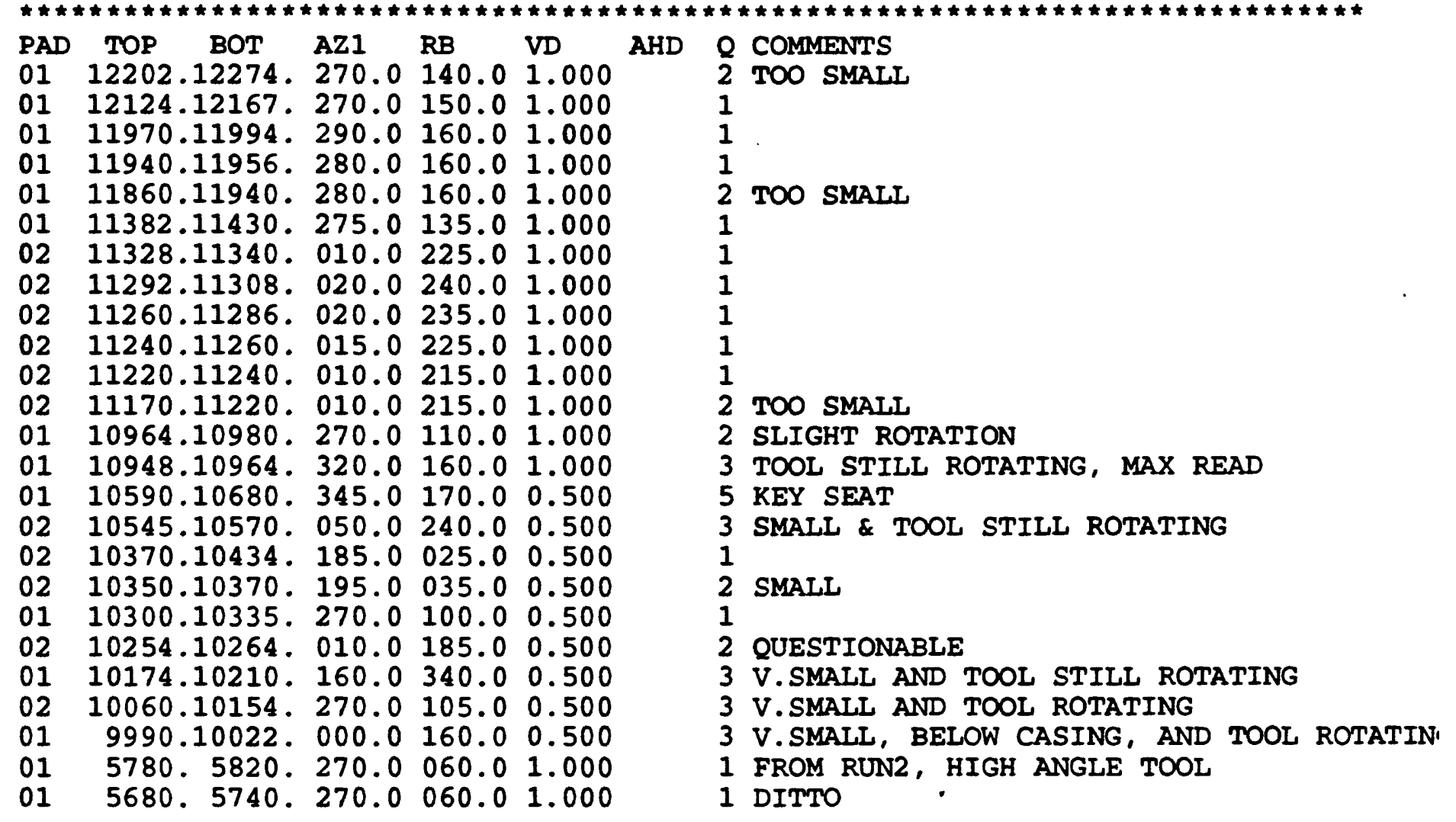

WASHINGTON STATE DATA

SHEARING 1

$\begin{array}{lllll}0 & \text { WA2 } 86 & 20.0 & 47.792 & -124.425\end{array}$

JEFFERSON CO. , WASHINGTON, PYRAMID PETROLEUM CORP.

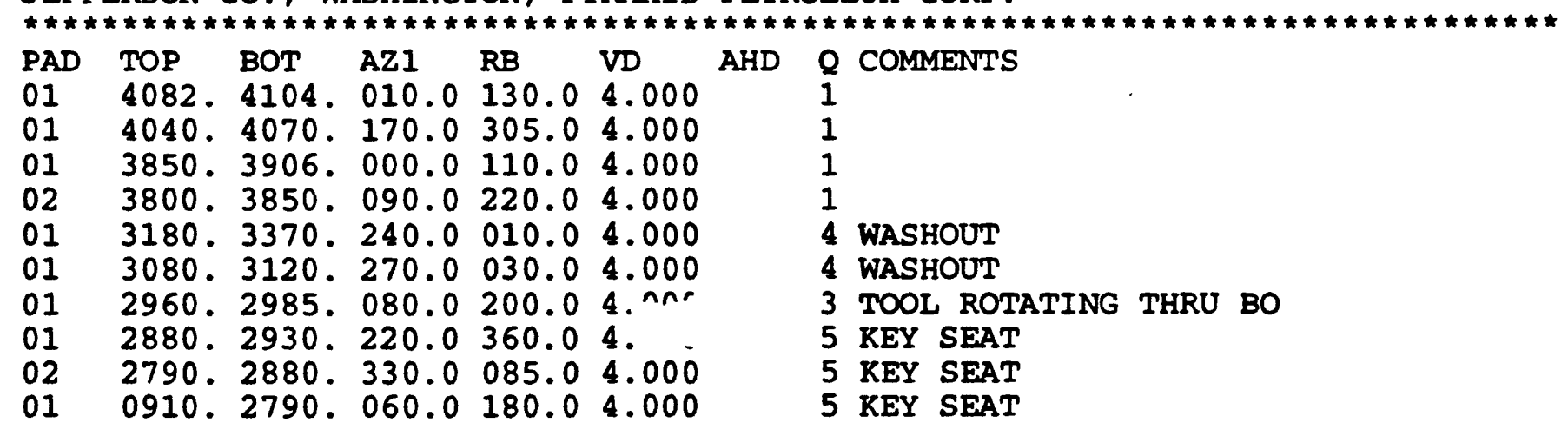


WASHINGTON STATE DATA

STATE \#1-30

2 WA303 $22.0 \quad 48.100 \quad-123.800$

CLALLUM CO. , WASHINGTON, TWIN RIVERS

PAD TOP BOT AZ1 RB VD AHD Q COMMENTS

015730.6600 .185 .0000 .07 .500015 .04 NO ROTATION

$015580.5660 .185 .0000 .07 .500 \quad 015.04 \mathrm{NR}$

025550.5580 .115 .0000 .07 .500 015.03 ROT ABOVE

$01 \quad 5210.5545 .200 .0000 .07 .500015 .03$ ROT BELOW

$01 \quad 5030.5190 .200 .0000 .07 .000 \quad 015.03$ ROT BELOW

$024850.4970 .120 .0 \quad 000.06 .000$ 015.05 END OF RUN; CONSISTENT REPEAT SECTION

$01409 \mathrm{C}, 4345.195 .0 \quad 0.03 .000015 .033$ SMALL BO'S-MAY SPIIT THIS LATER

$013994.4020 .060 .0 \quad 0.02 .500015 .01$ GOOD SHAPE; ROT ABOVE \& BELOW

$013750.3770 .035 .0 \quad 0.02 .250 \quad 005.02$

013590.3620 .120 .0

023520.3550 .300 .0

023220.3400 .100 .0

$02 \quad 3165.3220 .130 .0$

013080.3150 .220 .0

012980.3080 .180 .0

012832.2900 .250 .0

012800.2832 .255 .0

$02 \quad 2440.2700 .220 .0$

012310.2420 .280 .0

$02 \quad 2190.2240 .080 .0$

0.01 .750005 .03 GOOD ROT; POOR SHAPE

$0.01 .670 \quad 000.03$ DITTO

$0.01 .500 \quad 000.04$ wo

0.02 .000005 .02 ENDS IN WO BELOW

0.02 .000005 .02

0.02 .000010 .03 POOR SHAPE

0.02 .000010 .03 POOR SHAPE

0.02 .000010 .03 drifts-but use as mode 2, 1bo

0.01 .500025 .03 POOR SHAPE

0.01 .500040 .03 poor shape

0.01 .750035 .03 POOR SHAPE 
WASHINGTON STATE DATA

SHELL LUSE $1-23$

$\begin{array}{lllll}0 & \text { WA285 } & 20.0 & 46.208 & -124.135\end{array}$

GRAYS HARBOR CO., WASHINGTON, SHELL

\begin{tabular}{|c|c|c|c|c|c|c|c|c|}
\hline $\begin{array}{l}\text { PAD } \\
02 \\
02 \\
02 \\
02 \\
01 \\
02 \\
01\end{array}$ & $\begin{array}{l}\text { TOP } \\
3322 . \\
2760 . \\
2722 . \\
2480 . \\
2394 . \\
1970 . \\
1825 .\end{array}$ & $\begin{array}{l}\text { BOT } \\
3400 . \\
2772 . \\
2738 . \\
2524 . \\
2460 . \\
1996 . \\
1890 .\end{array}$ & $\begin{array}{l}\text { AZ1 } \\
075.0 \\
320.0 \\
240.0 \\
095.0 \\
0 \cap 0.0 \\
340.0 \\
250.0\end{array}$ & $\begin{array}{l}\mathrm{RB} \\
210.0 \\
150.0 \\
170.0 \\
280.0 \\
200.0 \\
200.0 \\
120.0\end{array}$ & $\begin{array}{l}\text { VD } \\
2.000 \\
2.000 \\
2.000 \\
2.000 \\
2.000 \\
2.000 \\
2.000\end{array}$ & AHD & $\begin{array}{l}Q \\
3 \\
2 \\
2 \\
3 \\
3 \\
2 \\
2\end{array}$ & $\begin{array}{l}\text { COMMIENTS } \\
\text { TOOL ROTATING } \\
\text { SMALL } \\
\text { SMALL } \\
\text { SMALL }\end{array}$ \\
\hline
\end{tabular}

WASHINGTON STATE DATA

SAMPSON JOHN'S 1-15

$\begin{array}{lllll}0 & \text { WA2 } 87 & 20.0 & 47.100 & -124.300\end{array}$

GRAYS HARBOR CO. , WASHINGTON, SHELL

\begin{tabular}{|c|c|c|c|c|c|c|c|}
\hline $\begin{array}{l}\text { PAD } \\
02 \\
02 \\
01 \\
01 \\
01\end{array}$ & $\begin{array}{l}\text { TOP } \\
1512 . \\
1485 . \\
1410 . \\
1346 . \\
1268 .\end{array}$ & $\begin{array}{l}\text { BOT } \\
1520 . \\
1500 . \\
1450 . \\
1410 . \\
1330 .\end{array}$ & $\begin{array}{l}\text { AZ1 } \\
325.0 \\
325.0 \\
010.0 \\
040.0 \\
060.0\end{array}$ & $\begin{array}{l}R B \\
070.0 \\
080.0 \\
140.0 \\
170.0 \\
200.0\end{array}$ & $\begin{array}{l}\text { VD } \\
2.000 \\
2.000 \\
2.000 \\
2.000 \\
2.000\end{array}$ & AHD & $\begin{array}{ll}Q & \text { COMMENTS } \\
1 & \\
5 & \text { KEYSEAT } \\
3 & \mathrm{~V} \text { SMALL } \\
5 & \text { KEYSEAT } \\
1 & \end{array}$ \\
\hline
\end{tabular}

WASHING'ION ST:- "T DATA

GRAYS HARBOR LHA $1-15$

$\begin{array}{lllll}0 & \text { WA2 } 88 & 2 i .0 & 47.135 & -124.146\end{array}$

GRAYS HARBOR CO., WASHINGTON, SHELI

\begin{tabular}{|c|c|c|c|c|c|c|c|}
\hline $\begin{array}{l}\text { PAD } \\
01 \\
01 \\
01\end{array}$ & $\begin{array}{l}\text { TOP } \\
1545 \\
1235 \\
540\end{array}$ & $\begin{array}{l}\text { BOT } \\
1565 \\
1300 \\
590\end{array}$ & $\begin{array}{l}\text { AZ1 } \\
055.0 \\
135.0 \\
080.0\end{array}$ & $\begin{array}{l}\text { RB } \\
115.0 \\
195.0 \\
065.0\end{array}$ & $\begin{array}{l}\mathrm{VD} \\
0.000 \\
0.000 \\
0.000\end{array}$ & AHD & $\begin{array}{l}\text { Q } \\
3 \text { COMMENTS } \\
2 \\
2 \\
2\end{array}$ \\
\hline
\end{tabular}


WASHINGTON STATE IATA

MONTESANO $1-\mathrm{X}$

$\begin{array}{lllll}0 & \text { WA2 } 4 & 20.0 & 46.958 & -123.625\end{array}$

GRAYS HARBOR, WASHINGTON, EL PASO PRODUCTS

PAD TOP BOT AZI RB VD

025472.5540 .160 .0315 .01 .000

AHD $Q$ COMMENTS

5220.5450 .290 .0100 .01 .200

$02 \quad 5190.5220 .320 .0140 .01 .200$

$02 \quad 5120.5180 .260 .0070 .01 .500$

02 5015.5106.220.0 040.02.000

$012954.2992 .235 .0 \quad 030.04 .000$

$012410.2930 .330 .0 \quad 030.06 .500$

2 VERY SMALL

2 VERY SMALL, KEY SEAT

2 SMALL

3 SMALL

3 SMALL

2 SMALL AND GRADUAL

2 LONG, SMALL, AND GRADUAL

$02 \quad 2150.2410 .145 .0080 .06 .000$

4 SLOWLY ROTATING OVER LENGTH

700. 1015. 335.0115 .05 .000

2 LARGE, ENDS IN WASHOUT

WASHINGTON STATE DATA

PLUM CREEK 23-2

2 WA289 $0.0 \quad 47.135 \quad-122.146$

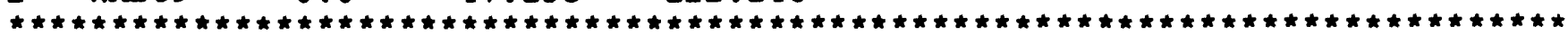

PIERCE CO., WASHINGTON, MERIDIAN OIL CO., READ FROM CPD LOG

PAD TOP BOT AZ1 RB VD AHD Q COMMENTS

$013330.3380 .231 .0 \quad 13.0237 .5$ KEY SEAT

013050.3180 .230 .0

$01 \quad 1580.1608 .234 .0$

13.0238 . 5 KEY SEAT

7.0 264. 4 WASHOUT

$01 \quad 660.1000 .268 .9$

3.0252 .3 QUESTIONABLE ROTATION 
IATITUDE $=48.9140$ IONGITUDE $=-122.7230$ DECIINATION $=23.0$ WHATCOM CO., WASHINGTON, AMERICAN HUNTER EXPI.

HORIZONTAL AZIMUTHS ARE MEASURED CLOCKWISE WITH RESPECT TO TRUE NORTH

\begin{tabular}{|c|c|c|c|c|c|c|c|c|}
\hline No. & $\begin{array}{l}\text { LENGTH } \\
\text { (FEET) }\end{array}$ & $\begin{array}{l}\text { NUMBER } \\
\text { OF B.O. }\end{array}$ & $\begin{array}{r}\text { QUALITY } \\
\text { FACTOR }\end{array}$ & $\begin{array}{l}\text { B.O. } \\
\text { AZIM. }\end{array}$ & $\begin{array}{l}\text { DEV. } \\
\text { AZIM. }\end{array}$ & $\begin{array}{l}\text { HOLE } \\
\text { DEV. }\end{array}$ & $\begin{array}{l}\text { INT. } \\
\text { TOP }\end{array}$ & $\begin{array}{l}\text { INT. } \\
\text { BOTTOM }\end{array}$ \\
\hline $\begin{array}{l}1 \\
2 \\
3 \\
4 \\
5 \\
6 \\
7 \\
8 \\
9 \\
10 \\
11 \\
12 \\
13 \\
14 \\
15 \\
16 \\
17 \\
18 \\
19 \\
20 \\
21 \\
22 \\
23 \\
24 \\
25 \\
26 \\
27 \\
28 \\
29 \\
30 \\
31 \\
32 \\
33 \\
34 \\
35 \\
36 \\
37 \\
38 \\
39 \\
40 \\
41 \\
42 \\
43 \\
44 \\
45 \\
46 \\
47 \\
48 \\
49 \\
50\end{array}$ & $\begin{array}{r}10.0 \\
12.0 \\
22.0 \\
74.0 \\
22.0 \\
62.0 \\
100.0 \\
16.0 \\
60.0 \\
56.0 \\
42.0 \\
56.0 \\
22.0 \\
14.0 \\
8.0 \\
52.0 \\
22.0 \\
16.0 \\
70.0 \\
10.0 \\
10.0 \\
10.0 \\
14.0 \\
80.0 \\
68.0 \\
10.0 \\
44.0 \\
26.0 \\
60.0 \\
12.0 \\
8.0 \\
12.0 \\
48.0 \\
68.0 \\
14.0 \\
34.0 \\
20.0 \\
25.0 \\
36.0 \\
12.0 \\
28.0 \\
50.0 \\
192.0 \\
83.0 \\
78.0 \\
138.0 \\
114.0 \\
58.0 \\
86.0 \\
66.0\end{array}$ & $\begin{array}{l}1.0 \\
1.0 \\
1.0 \\
1.0 \\
1.0 \\
1.0 \\
1.0 \\
1.0 \\
1.0 \\
1.0 \\
1.0 \\
1.0 \\
1.0 \\
1.0 \\
1.0 \\
1.0 \\
1.0 \\
1.0 \\
1.0 \\
1.0 \\
1.0 \\
1.0 \\
1.0 \\
1.0 \\
1.0 \\
1.0 \\
1.0 \\
1.0 \\
1.0 \\
1.0 \\
1.0 \\
1.0 \\
1.0 \\
1.0 \\
1.0 \\
1.0 \\
1.0 \\
1.0 \\
1.0 \\
1.0 \\
1.0 \\
1.0 \\
1.0 \\
1.0 \\
1.0 \\
1.0 \\
1.0 \\
1.0 \\
1.0 \\
1.0\end{array}$ & $\begin{array}{l}2 \\
2 \\
2 \\
5 \\
4 \\
5 \\
2 \\
2 \\
2 \\
4 \\
4 \\
5 \\
2 \\
2 \\
4 \\
3 \\
1 \\
1 \\
4 \\
3 \\
3 \\
5 \\
3 \\
2 \\
4 \\
4 \\
4 \\
2 \\
3 \\
2 \\
3 \\
4 \\
4 \\
4 \\
4 \\
4 \\
4 \\
4 \\
2 \\
4 \\
2 \\
4 \\
3 \\
4 \\
2 \\
2 \\
4 \\
4 \\
3 \\
3\end{array}$ & $\begin{array}{r}-87.0 \\
83.0 \\
-82.0 \\
83.0 \\
-27.0 \\
78.0 \\
-82.0 \\
-87.0 \\
88.0 \\
-57.0 \\
-67.0 \\
63.0 \\
-47.0 \\
-72.0 \\
-7.0 \\
-62.0 \\
-67.0 \\
-62.0 \\
-87.0 \\
-87.0 \\
-87.0 \\
33.0 \\
-77.0 \\
-87.0\end{array}$ & 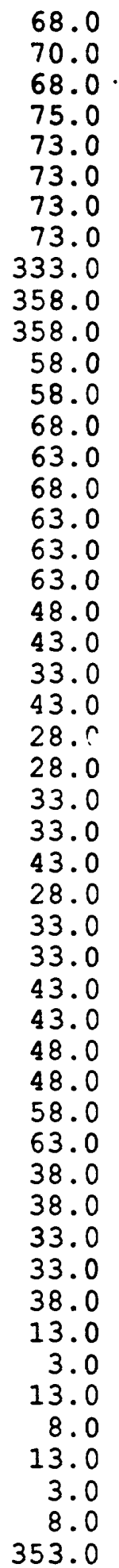 & $\begin{array}{l}0.5 \\
0.8 \\
0.8 \\
1.0 \\
1.0 \\
1.0 \\
0.0 \\
0.0 \\
0.8 \\
1.0 \\
0.0 \\
0.5 \\
0.8 \\
0.8 \\
2.0 \\
2.0 \\
1.8 \\
2.0 \\
2.0 \\
2.0 \\
1.5 \\
2.0 \\
1.5 \\
1.8 \\
2.0 \\
2.0 \\
1.5 \\
1.5 \\
2.0 \\
3.0 \\
3.0 \\
2.5 \\
3.0 \\
3.0 \\
3.5 \\
3.0 \\
3.0 \\
2.5 \\
3.0 \\
3.0 \\
3.5 \\
4.0 \\
3.0 \\
2.8 \\
2.5 \\
2.0 \\
2.5 \\
2.8 \\
2.8 \\
2.3\end{array}$ & $\begin{array}{l}1202.0 \\
1216.0 \\
1242.0 \\
1386.0 \\
1464.0 \\
1488.0 \\
2170.0 \\
2274.0 \\
2362.0 \\
2440.0 \\
2846.0 \\
2914.0 \\
2970.0 \\
3066.0 \\
3142.0 \\
3206.0 \\
3260.0 \\
3284.0 \\
3300.0 \\
3390.0 \\
3550.0 \\
3562.0 \\
3676.0 \\
3816.0 \\
3900.0 \\
4008.0 \\
4100.0 \\
4144.0 \\
4280.0 \\
4646.0 \\
4678.0 \\
4924.0 \\
4990.0 \\
5102.0 \\
5352.0 \\
5534.0 \\
5590.0 \\
5950.0 \\
6004.0 \\
6114.0 \\
6202.0 \\
6350.0 \\
6550.0 \\
6755.0 \\
6842.0 \\
6968.0 \\
7550.0 \\
7712.0 \\
7814.0 \\
8004.0\end{array}$ & $\begin{array}{l}1212.0 \\
1228.0 \\
1264.0 \\
1460.0 \\
1486.0 \\
1550.0 \\
2270.0 \\
2290.0 \\
2422.0 \\
2496.0 \\
2888.0 \\
2970.0 \\
2992.0 \\
3080.0 \\
3150.0 \\
3258.0 \\
3282.0 \\
3300.0 \\
3370.0 \\
3400.0 \\
3560.0 \\
3572.0 \\
3690.0 \\
3896.0 \\
3968.0 \\
4018.0 \\
4144.0 \\
4170.0 \\
4340.0 \\
4658.0 \\
4686.0 \\
4936.0 \\
5038.0 \\
5170.0 \\
5366.0 \\
5568.0 \\
5610.0 \\
5975.0 \\
6040.0 \\
6126.0 \\
6230.0 \\
6400.0 \\
6742.0 \\
6838.0 \\
6920.0 \\
7106.0 \\
7664.0 \\
7770.0 \\
7900.0 \\
8070.0\end{array}$ \\
\hline
\end{tabular}




$\begin{array}{rrrrrrrrr}51 & 32.0 & 1.0 & 3 & -82.0 & 35.0 & 2.5 & 8074.0 & 8106.0 \\ 52 & 60.0 & 1.0 & 3 & 63.0 & 348.0 & 3.5 & 8110.0 & 8170.0 \\ 53 & 88.0 & 1.0 & 3 & 83.0 & 333.0 & 5.5 & 8302.0 & 8390.0 \\ 54 & 70.0 & 1.0 & 4 & 78.0 & 323.0 & 6.5 & 8410.0 & 8480.0\end{array}$

FOR DATA OF QUALITY 4 OR BETTER (INCLUDES 50 BREAKOUTS)
FOR DATA OF QUALITY 2 OR BETTER (INCLUDES 17 BREAKOUTS)

STATISTICS WEIGHTED BY BREAK OUT LENGTHS

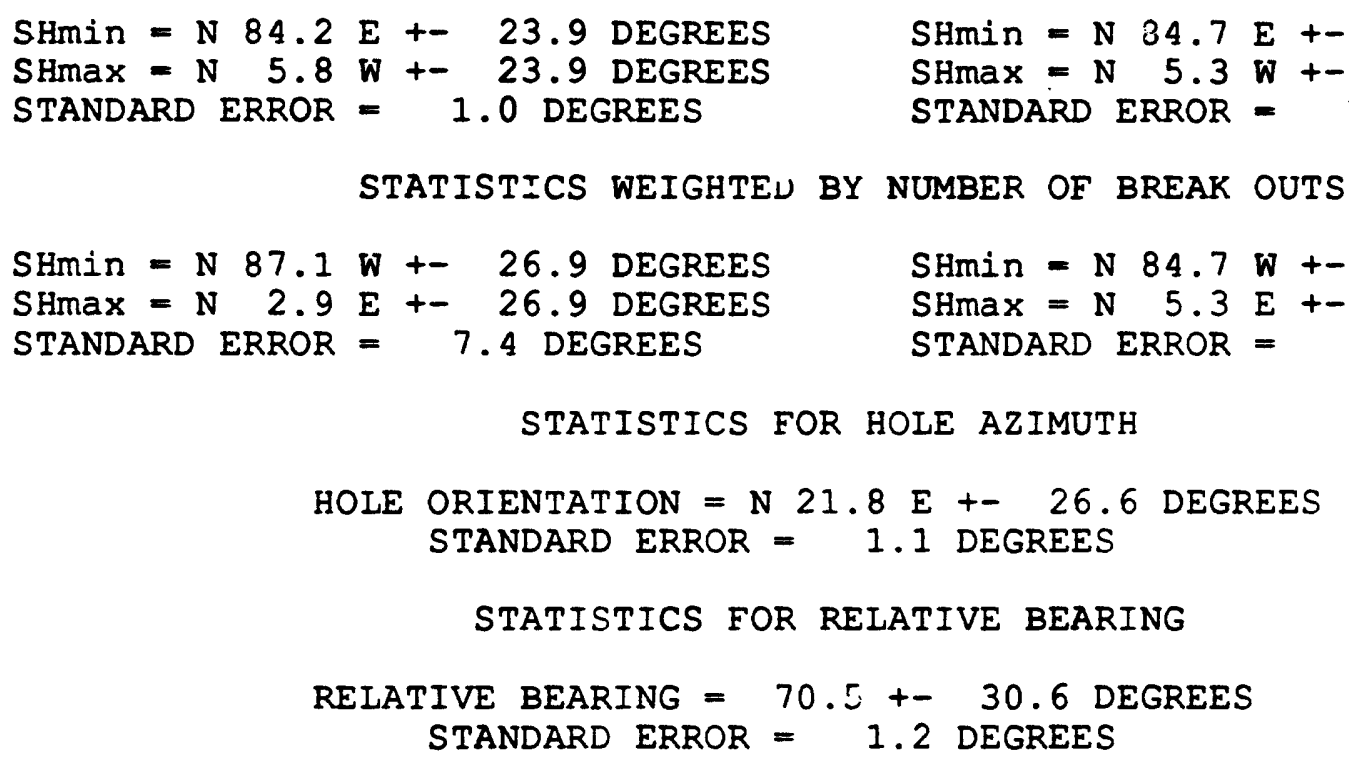

STATISTICS FOR HOLE AZIMUTH 
LATITUDE $=48.0700$ LONGITUDE $=-122.4000$ DECLINATION $=20.0$

ISLAND CO., WASHINGTON, STANDARD OIL CO. OF CALIFORNIA, WHIDBEY \#1

HORIZONTAL AZIMUTHS ARE MEASURED CLOCKWISE WITH RESPECT TO TRUE NORTH

\begin{tabular}{|c|c|c|c|c|c|c|c|c|}
\hline No. & $\begin{array}{l}\text { LENGTH } \\
\text { (FEET) }\end{array}$ & $\begin{array}{l}\text { NUMBER } \\
\text { OF B.O. }\end{array}$ & $\begin{array}{l}\text { QUALITY } \\
\text { FACTOR }\end{array}$ & $\begin{array}{l}\text { B.O. } \\
\text { AZIM. }\end{array}$ & $\begin{array}{l}\text { DEV. } \\
\text { AZIM. }\end{array}$ & $\begin{array}{l}\text { HOT,E } \\
\text { DEV. }\end{array}$ & $\begin{array}{l}\text { INT. } \\
\text { TOP }\end{array}$ & $\begin{array}{l}\text { INT. } \\
\text { BOTTOM }\end{array}$ \\
\hline $\begin{array}{r}1 \\
2 \\
3 \\
4 \\
5 \\
6 \\
7 \\
8 \\
9 \\
10 \\
11 \\
12 \\
13 \\
14 \\
15 \\
16 \\
17 \\
18 \\
19 \\
20 \\
21 \\
22 \\
23 \\
24 \\
25 \\
26 \\
27 \\
28 \\
29 \\
30 \\
31 \\
32 \\
33 \\
34 \\
35 \\
36 \\
37 \\
38 \\
39 \\
40 \\
41 \\
42 \\
43 \\
44 \\
45 \\
46 \\
47 \\
48 \\
49 \\
50\end{array}$ & $\begin{array}{r}36.0 \\
14.0 \\
10.0 \\
6.0 \\
8.0 \\
10.0 \\
6.0 \\
30.0 \\
157.0 \\
16.0 \\
45.0 \\
12.0 \\
14.0 \\
40.0 \\
66.0 \\
190.0 \\
64.0 \\
24.0 \\
10.0 \\
6.0 \\
96.0 \\
43.0 \\
384.0 \\
66.0 \\
100.0 \\
128.0 \\
62.0 \\
86.0 \\
14.0 \\
10.0 \\
14.0 \\
14.0 \\
14.0 \\
16.0 \\
10.0 \\
130 \\
780.0 \\
430 \\
19.0 \\
42.0 \\
66.0 \\
33.0 \\
95.0 \\
64.0 \\
68.0 \\
12.0 \\
16.0 \\
56.0 \\
27.0\end{array}$ & $\begin{array}{l}1.0 \\
1.0 \\
1.0 \\
1.0 \\
1.0 \\
1.0 \\
1.0 \\
1.0 \\
1.0 \\
1.0 \\
1.0 \\
1.0 \\
1.0 \\
1.0 \\
1.0 \\
1.0 \\
1.0 \\
1.0 \\
1.0 \\
1.0 \\
1.0 \\
1.0 \\
1.0 \\
1.0 \\
1.0 \\
1.0 \\
1.0 \\
1.0 \\
1.0 \\
1.0 \\
1.0 \\
1.0 \\
1.0 \\
1.0 \\
1.0 \\
1.0 \\
1.0 \\
1.0 \\
1.0 \\
1.0 \\
1.0 \\
1.0 \\
1.0 \\
1.0 \\
1.0 \\
1.0 \\
1.0 \\
1.0 \\
1.0 \\
1.0\end{array}$ & $\begin{array}{l}3 \\
3 \\
3 \\
3 \\
3 \\
5 \\
3 \\
4 \\
1 \\
1 \\
1 \\
1 \\
1 \\
1 \\
1 \\
1 \\
1 \\
4 \\
3 \\
3 \\
3 \\
5 \\
4 \\
5 \\
5 \\
5 \\
4 \\
4 \\
4 \\
3 \\
3 \\
3 \\
3 \\
5 \\
5 \\
5 \\
5 \\
4 \\
5 \\
5 \\
3 \\
3 \\
4 \\
4 \\
3 \\
5 \\
2 \\
3 \\
2 \\
3\end{array}$ & $\begin{array}{r}30.0 \\
40.0 \\
45.0 \\
-60.0 \\
-50.0 \\
-35.0 \\
-65.0 \\
-90.0 \\
-75.0 \\
-85.0 \\
-60 \\
-60.0 \\
-75.0 \\
-70.0 \\
-85.0 \\
-85.0 \\
-80.0 \\
-55.0 \\
-53.0 \\
85.0 \\
-30.0 \\
-65.0 \\
-25.0 \\
-20.0\end{array}$ & 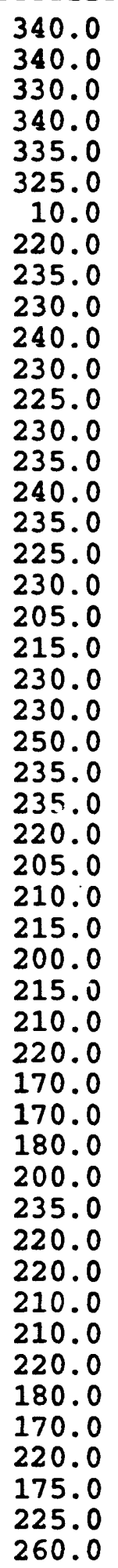 & $\begin{array}{l}2.5 \\
2.5 \\
2.8 \\
2.8 \\
2.3 \\
1.5 \\
0.0 \\
0.0 \\
1.0 \\
0.5 \\
0.5 \\
1.3 \\
1.0 \\
1.0 \\
1.0 \\
1.8 \\
2.0 \\
1.8 \\
2.0 \\
2.5 \\
3.0 \\
4.0 \\
4.0 \\
4.5 \\
4.5 \\
4.5 \\
4.5 \\
4.5 \\
4.5 \\
4.0 \\
3.8 \\
3.5 \\
3.5 \\
3.5 \\
4.0 \\
4.0 \\
4.0 \\
4.0 \\
5.0 \\
5.0 \\
3.0 \\
5.0 \\
5.0 \\
4.5 \\
4.5 \\
4.5 \\
4.3 \\
4.3 \\
2.3 \\
2.3\end{array}$ & $\begin{array}{l}6656.0 \\
6622.0 \\
6612.0 \\
6584.0 \\
6572.0 \\
6504.0 \\
6232.0 \\
5960.0 \\
5728.0 \\
5696.0 \\
5645.0 \\
5548.0 \\
5510.0 \\
5470.0 \\
5384.0 \\
5120.0 \\
5026.0 \\
4984.0 \\
4838.0 \\
4824.0 \\
4602.0 \\
4515.0 \\
4130.0 \\
4064.0 \\
3950.0 \\
3822.0 \\
3760.0 \\
3664.0 \\
3600.0 \\
3572.0 \\
3476.0 \\
3444.0 \\
3426.0 \\
3392.0 \\
3382.0 \\
3375.0 \\
3356.0 \\
3130.0 \\
3066.0 \\
2998.0 \\
2984.0 \\
2948.0 \\
2884.0 \\
2846.0 \\
2538.0 \\
2338.0 \\
2264.0 \\
1600.0 \\
1442.0 \\
1160.0\end{array}$ & $\begin{array}{l}6 i 92.0 \\
6636.0 \\
6622.0 \\
6590.0 \\
6580.0 \\
6514.0 \\
6238.0 \\
5990.0 \\
5885.0 \\
5712.0 \\
5690.0 \\
5560.0 \\
5524.0 \\
5510.0 \\
5450.0 \\
5310.0 \\
5090.0 \\
5008.0 \\
4848.0 \\
4830.0 \\
4698.0 \\
4558.0 \\
4514.0 \\
4130.0 \\
4050.0 \\
3950.0 \\
3822.0 \\
3750.0 \\
3614.0 \\
3582.0 \\
3490.0 \\
3458.0 \\
3440.0 \\
3408.0 \\
3392.0 \\
3382.0 \\
3375.0 \\
3225.0 \\
3130.0 \\
3066.0 \\
2996.0 \\
2964.0 \\
2940.0 \\
2873.0 \\
2400.0 \\
2380.0 \\
2330.0 \\
2260.0 \\
1475.0 \\
1440.0\end{array}$ \\
\hline
\end{tabular}


FOR DATA OF QUALITY 4 OR BETTER

(INCLUDES 38 BREAKOUTS)
FOR DATA OF OUAI ITY 1 OR BETTER (INCLUDES 9 SREAKOUTS)

STATISTICS WEIGHTED BY BREAK OUT LENGTHS

SHmin $=$ N 27.1 E +-37.5 DEGREES

SHmaX $=\mathrm{N} 62.9 \mathrm{~W}+-37.5$ DEGREES

STANDARD ERROR $=1.4$ DEGREES

$$
\begin{aligned}
& \text { SHmin }=\mathrm{N} 75.4 \mathrm{~W}+-\quad 9.2 \text { DEGREES } \\
& \text { SHmax }=\mathrm{N} 14.6 \mathrm{E}+-\quad 9.2 \text { DEGREES } \\
& \text { STANDARD ERROR }=\quad 0.7 \text { DEGREES }
\end{aligned}
$$

\section{STATISTICS WEIGHTED BY NUMBER OF BREAK OUTS}

SHmin $=\mathrm{N} 85.2 \mathrm{~W}+-35.9$ DEGREES

SHmax $=\mathrm{N} 4.8 \mathrm{E}+-35.9$ DEGREES

STANDARD ERROR $=11.4$ DEGREES
SHmin $=\mathrm{N} 74.6 \mathrm{~W}+-10.3$ NEGREES

SHmax $=N 15.4 \mathrm{E}+-10.3 \mathrm{DEGI}$ EES

STANDARD ERROR $=8.4$ DEGREES

STATISTICS FOR HOLE AZIMUTH

HOLE ORIENTATION $=\mathrm{N} 34.6 \mathrm{E}+-27.1$ DEGREES

STANDARD ERROR $=1.0$ DEGREES

STATISTICS FOR RELATIVE BEARING

RELATIVE BEARING $=60.1+31.0$ DEGREES

STANDARD ERROR $=1.1$ DEGREES 
LATITUDE $=48.0700$ LONGITUDE $=-122.4000$ DECLINATION $=20.0$

ISLAND CO., WASHINGTON, STANDARD OIL CO. OF CALIFORNIA, WHIDBEY \# 1

HORIZONTAL AZIMUTHS ARE MEASURED CLOCKWISE WITH RESPECT TO TRUE NORTH

LENGTH NUMBER QUALITY B.O. DEV. HOLE INT. INT. NO. (FEET) OF B.O. FACTOR AZIM. AZIM. DEV. TOP 'BOTTOM

\begin{tabular}{|c|c|c|c|c|c|c|c|c|}
\hline $\begin{array}{l}1 \\
2 \\
3 \\
4 \\
5 \\
6\end{array}$ & $\begin{array}{r}138.0 \\
42.0 \\
66.0 \\
660.0 \\
33.0 \\
280.0\end{array}$ & $\begin{array}{l}1.0 \\
1.0 \\
1.0 \\
1.0 \\
1.0 \\
1.0\end{array}$ & $\begin{array}{l}3 \\
5 \\
2 \\
3 \\
2 \\
3\end{array}$ & $\begin{array}{r}40.0 \\
-10.0 \\
-10.0 \\
40.0 \\
-25.0 \\
10.0\end{array}$ & $\begin{array}{l}180.0 \\
170.0 \\
220.0 \\
175.0 \\
225.0 \\
260.0\end{array}$ & $\begin{array}{l}4.5 \\
4.5 \\
4.3 \\
4.3 \\
2.3 \\
2.3\end{array}$ & $\begin{array}{l}2538.0 \\
2338.0 \\
2264.0 \\
1600.0 \\
1442.0 \\
1160.0\end{array}$ & $\begin{array}{l}2400.0 \\
2380.0 \\
2330.0 \\
2260.0 \\
1475.0 \\
1440.0\end{array}$ \\
\hline
\end{tabular}

FOR DATA OF QUALITY 3 OR BETTER

(INCLUDES 5 BREAKOUTS)

STATISTICS WEIGHTED BY BREAK OUT LENGTHS

SHmin $=\mathrm{N} 29.9 \mathrm{E}+-17.2$ DEGREES

SHmaX $=\mathrm{N} 60.1 \mathrm{~W}+-17.2$ DEGREES

STANDARD ERROR $=1.0$ DEGREES

STATISTICS WEIGHTED BY NUMBER OF BREAK OUTS

SHmin $=\mathrm{N} 11.4 \mathrm{E}+-24.9$ DEGREES

SHmaX $=\mathrm{N} 78.6 \mathrm{~W}+-24.9$ DEGREES

STANDARD ERROR $=34.6$ DEGREES

STATISTICS FOR HOLE AZIMUTH

HOLE ORIENTATION $=\mathrm{N} 4.2 \mathrm{E}+-29.8$ DEGREES

STANDARD ERROR $=1.7$ DEGREES

STATISTICS FOR RELATIVE BEARING

RELATIVE BEARING $=56.6+-\quad 0.0$ DEGREES

STANDARD ERROR $=0.0$ DEGREES 
LATITUDE $=47.8080$ LONGITUDE $=-122.5000$ DECLINATION $=22.0$

KITSAP CO., WASHINGTON, MOBIL OIL CO.

HORIZONTAL AZIMUTHS ARE MEASURED CLOCKWISE WITH RESPECT TO TRUE NORTH

LENGTH NUMBER QUALITY B.O. DEV. HOLE INT. INT. NO. (FEET) OF B.O. FACTOR AZIM. AZIM. DEV. TOP BOTTOM

\begin{tabular}{|c|c|c|c|c|c|c|c|c|}
\hline $\begin{array}{r}1 \\
2 \\
3 \\
4 \\
5 \\
6 \\
7 \\
8 \\
9 \\
10 \\
11 \\
12 \\
13 \\
14 \\
15 \\
16 \\
17 \\
18\end{array}$ & $\begin{array}{r}6.0 \\
66.0 \\
110.0 \\
116.0 \\
48.0 \\
8.0 \\
10.0 \\
70.0 \\
153.0 \\
18.0 \\
76.0 \\
124.0 \\
15.0 \\
46.0 \\
304.0 \\
36.0 \\
280.0 \\
650.0\end{array}$ & $\begin{array}{l}1.0 \\
1.0 \\
1.0 \\
1.0 \\
1.0 \\
1.0 \\
1.0 \\
1.0 \\
1.0 \\
1.0 \\
1.0 \\
1.0 \\
1.0 \\
1.0 \\
1.0 \\
1.0 \\
1.0 \\
1.0\end{array}$ & $\begin{array}{l}3 \\
5 \\
5 \\
5 \\
2 \\
2 \\
2 \\
1 \\
1 \\
1 \\
1 \\
1 \\
2 \\
1 \\
1 \\
2\end{array}$ & $\begin{array}{r}-28.0 \\
12.0 \\
17.0 \\
7.0 \\
12.0 \\
12.0 \\
12.0 \\
22.0 \\
22.0 \\
22.0 \\
-3.0 \\
2.0 \\
42.0 \\
22.0 \\
42.0 \\
62.0 \\
32.0 \\
27.0\end{array}$ & $\begin{array}{r}202.0 \\
202.0 \\
192.0 \\
187.0 \\
177.0 \\
162.0 \\
162.0 \\
172.0 \\
172.0 \\
172.0 \\
277.0 \\
162.0 \\
152.0 \\
152.0 \\
162.0 \\
162.0 \\
152.0 \\
82.0\end{array}$ & $\begin{array}{l}2.0 \\
2.0 \\
2.0 \\
2.0 \\
2.0 \\
2.0 \\
2.0 \\
2.0 \\
2.0 \\
2.0 \\
2.0 \\
2.0 \\
2.0 \\
2.0 \\
2.0 \\
2.0 \\
2.0 \\
2.0\end{array}$ & $\begin{array}{l}5000.0 \\
4914.0 \\
4780.0 \\
4596.0 \\
4310.0 \\
4226.0 \\
4206.0 \\
3984.0 \\
3584.0 \\
3516.0 \\
3434.0 \\
3310.0 \\
3275.0 \\
3214.0 \\
2910.0 \\
2670.0 \\
2370.0 \\
1660.0\end{array}$ & $\begin{array}{l}5006.0 \\
4980.0 \\
4890.0 \\
4712.0 \\
4358.0 \\
4234.0 \\
4216.0 \\
4054.0 \\
3737.0 \\
3534.0 \\
3510.0 \\
3434.0 \\
3290.0 \\
3260.0 \\
3214.0 \\
2706.0 \\
2650.0 \\
2310.0\end{array}$ \\
\hline
\end{tabular}

FOR DATA OF QUALITY 4 OR BETTER (INCLUDES 15 BREAKOUTS)
FOR DATA OF QUALITY 2 OR BETTER (INCLUDES 14 BREAKOUTS)

STATISTICS WEIGHTED BY BREAK OUT LENGTHS

\begin{abstract}
SHmin $=N 26.9 \mathrm{E}+-12.5$ DEGREES
SHmax $=\mathrm{N} 63.1 \mathrm{~W}+-12.5$ DEGREES

STANDARD ERROR $=0.6$ DEGREES
\end{abstract}

\begin{abstract}
SHmin $=\mathrm{N} 27.0 \mathrm{E}+-12.2$ DEGREES
SHmax $=\mathrm{N} 63.0 \mathrm{~W}+-12.2$ DEGREES

STANDARD ERROR $=0.6$ DEGREES
\end{abstract}

STATISTICS WEIGHTED BY NUMBER OF BREAK OUTS

SHmin $=\mathrm{N} 20.4 \mathrm{E}+-19.0$ DEGREES

SHmax $=\mathrm{N} 69.6 \mathrm{~W}+-19.0$ DEGREES

STANDARD ERROR $=10.9$ DEGREES
SHmin $=N 22.8 \mathrm{E}+-15.8$ DEGREES

SHmax $=\mathrm{N} 67.2 \mathrm{~W}+-15.8$ DEGRFES

STANDARD ERROR $=9.5$ DEGREES

STATISTICS FOR HOLE AZIMUTH

HOLE ORIENTATION $=\mathrm{N} 35.3 \mathrm{~W}+-34.6$ DEGREES

STANDARD ERROR $=1.6$ DEGREES

STATISTICS FOR RELATIVE BEARING

RELATIVE BEARING $=70.2+-34.8$ DEGREES

STANDARD ERROR $=1.6$ DEGREES 
LATITUDE $=47.7920$ LONGITUDE $=-122.2510$ DECLINATION $=22.0$ SNOHOMISH CO., WASHINGTON, STANDARD OIL CO. OF CALIFORNIA, SCHROEDER \#1 HORIZONTAL AZIMUTHS ARE MEASURED CLOCKWISE WITH RESPECT TO TRUE NORTH

LENGTH NUMBER QUALITY B.O. DEV. HOLE INT. INT. NO. (FEET) OF B.O. FACTOR AZIM. AZIM. DEV. TOP BOTTOM

\begin{tabular}{|c|c|c|c|c|c|c|c|c|}
\hline $\begin{array}{r}1 \\
2 \\
3 \\
4 \\
5 \\
6 \\
7 \\
8 \\
9 \\
10 \\
11 \\
12 \\
13 \\
14 \\
15 \\
16 \\
17 \\
18 \\
19 \\
20 \\
21 \\
22 \\
23 \\
24 \\
25 \\
26 \\
27 \\
28 \\
29 \\
30 \\
31 \\
32 \\
33 \\
34 \\
35 \\
36 \\
37\end{array}$ & $\begin{array}{r}60.0 \\
85.0 \\
46.0 \\
54.0 \\
5.0 \\
50.0 \\
24.0 \\
376.0 \\
14.0 \\
76.0 \\
255.0 \\
20.0 \\
226.0 \\
60.0 \\
310.0 \\
110.0 \\
90.0 \\
30.0 \\
6.0 \\
22.0 \\
8.0 \\
16.0 \\
78.0 \\
110.0 \\
92.0 \\
24.0 \\
616.0 \\
60.0 \\
270.0 \\
110.0 \\
154.0 \\
26.0 \\
20.0 \\
26.0 \\
16.0 \\
144.0 \\
260.0\end{array}$ & $\begin{array}{l}1.0 \\
1.0 \\
1.0 \\
1.0 \\
1.0 \\
1.0 \\
1.0 \\
1.0 \\
1.0 \\
1.0 \\
1.0 \\
1.0 \\
1.0 \\
1.0 \\
1.0 \\
1.0 \\
1.0 \\
1.0 \\
1.0 \\
1.0 \\
1.0 \\
1.0 \\
1.0 \\
1.0 \\
1.0 \\
1.0 \\
1.0 \\
1.0 \\
1.0 \\
1.0 \\
1.0 \\
1.0 \\
1.0 \\
1.0 \\
1.0 \\
1.0\end{array}$ & $\begin{array}{l}4 \\
2 \\
2 \\
2 \\
2 \\
2 \\
2 \\
1 \\
1 \\
3 \\
1 \\
2 \\
2 \\
2 \\
2 \\
3 \\
3 \\
3 \\
4 \\
3 \\
3 \\
3 \\
5 \\
5 \\
5 \\
3 \\
5 \\
4 \\
3 \\
5 \\
5 \\
5 \\
5 \\
3 \\
3 \\
5 \\
5\end{array}$ & $\begin{array}{r}-78.0 \\
27.0 \\
17.0 \\
12.0 \\
-3.0 \\
-8.0 \\
-28.0 \\
-13.0 \\
-13.0 \\
-13.0 \\
-8.0 \\
17.0 \\
12.0 \\
12.0 \\
-8.0 \\
72.0 \\
62.0 \\
22.0 \\
-68.0 \\
67.0 \\
62.0 \\
62.0 \\
72.0 \\
62.0 \\
72.0 \\
52.0 \\
32.0 \\
-78.0 \\
62.0 \\
47.0 \\
52.0 \\
72.0 \\
87.0 \\
62.0 \\
47.0 \\
22.0 \\
22.0\end{array}$ & $\begin{array}{r}82.0 \\
47.0 \\
42.0 \\
27.0 \\
32.0 \\
37.0 \\
52.0 \\
52.0 \\
52.0 \\
57.0 \\
102.0 \\
112.0 \\
112.0 \\
132.0 \\
42.0 \\
122.0 \\
102.0 \\
112.0 \\
82.0 \\
97.0 \\
102.0 \\
102.0 \\
242.0 \\
72.0 \\
247.0 \\
142.0 \\
212.0 \\
207.0 \\
212.0 \\
47.0 \\
62.0 \\
82.0 \\
167.0 \\
142.0 \\
112.0 \\
22.0 \\
212.0\end{array}$ & $\begin{array}{l}3.0 \\
2.0 \\
2.0 \\
1.5 \\
1.5 \\
1.5 \\
1.5 \\
3.0 \\
2.8 \\
2.8 \\
3.0 \\
3.0 \\
3.0 \\
2.5 \\
2.0 \\
2.0 \\
1.0 \\
1.3 \\
1.0 \\
1.8 \\
1.8 \\
1.8 \\
1.0 \\
1.3 \\
2.1 \\
1.0 \\
1.8 \\
1.8 \\
1.8 \\
1.5 \\
1.5 \\
1.5 \\
0.5 \\
0.8 \\
0.8 \\
1.3 \\
1.0\end{array}$ & $\begin{array}{l}9420.0 \\
9300.0 \\
9250.0 \\
9178.0 \\
9036.0 \\
8920.0 \\
8896.0 \\
8394.0 \\
8352.0 \\
8240.0 \\
7930.0 \\
7880.0 \\
7594.0 \\
7390.0 \\
7010.0 \\
6840.0 \\
6550.0 \\
6520.0 \\
6346.0 \\
6252.0 \\
6176.0 \\
5920.0 \\
5542.0 \\
5130.0 \\
4648.0 \\
4186.0 \\
3334.0 \\
3270.0 \\
2990.0 \\
2830.0 \\
2676.0 \\
2650.0 \\
2240.0 \\
2160.0 \\
2134.0 \\
1910.0 \\
1580.0\end{array}$ & $\begin{array}{l}9480.0 \\
9385.0 \\
9296.0 \\
9232.0 \\
9041.0 \\
8970.0 \\
8920.0 \\
8770.0 \\
8366.0 \\
8316.0 \\
8185.0 \\
7900.0 \\
7820.0 \\
7450.0 \\
7320.0 \\
6950.0 \\
6640.0 \\
6550.0 \\
6352.0 \\
6274.0 \\
6184.0 \\
5936.0 \\
5620.0 \\
5240.0 \\
4740.0 \\
4210.0 \\
3950.0 \\
3330.0 \\
3260.0 \\
2940.0 \\
2830.0 \\
2676.0 \\
2260.0 \\
2186.0 \\
2150.0 \\
2054.0 \\
1840.0\end{array}$ \\
\hline
\end{tabular}


FOR DATA OF QUALITY 4 OR BETTER

(INCLUDES 27 BREAKOUTS)
FOR DATA OF QUALITY 2 OR BETTER (INCLUDES 13 BREAKOUTS)

STATISTICS WEIGHTED BY BREAK OUT LENGTHS

SHmin $=\mathrm{N} 7.7 \mathrm{E}+-30.1$ DEGREES

SHmin $=\mathrm{N} 2.4 \mathrm{~W}+-12.5$ DEGREES

SHmax $=\mathrm{N} 82.3 \mathrm{~W}+-30.1$ DEGREES

SHmax $=\mathrm{N} 87.6 \mathrm{E}+-12.5$ DEGREES

STANDARD ERROR $=1.2$ DEGREES

STANDARD ERROR $=0.6$ DEGREES

STATISTICS WEIGHTED BY NUMBER OF BREAK OUTS

SHin $=N 24.8 \mathrm{E}+-33.3$ DEGREES

SHIMin $=N 1.3 \mathrm{~N}+-14.9$ DEGREES

SHmax $=\mathrm{N} 65.2 \mathrm{~W}+-33.3$ DEGREES

SHmax $=\mathrm{N} 88.7 \mathrm{~W}+-14.9$ DEGREES

STANDARD ERROR $=13.4$ DEGREES

STANDARD ERROR $=9.4$ DEGREES

STATISTICS FOR HOLE AZIMUTH

HOLE ORIENTATION $=\mathrm{N} 63.7 \mathrm{E}+-31.3$ DEGREES

STANDARD ERROR $=1.3$ DEGREES

STATISTICS FOR RELATIVE BEARING

RELATIVE BEARING $=71.4+-32.8$ DEGREES

STANDARD ERROR $=1.3$ DEGREES 
LATITUDE $=47.7920$ LONGITUDE $=-122.2510$ DECLINATION $=22.0$ SNOHOMISH CO., WASHINGTON, STANDARD OIL CO. OF CALIFORNIA, SCHROEDER \#1 HORIZONTAL AZIMUTHS ARE MEASURED CLOCKWISE WITH RESPECT TO TRUE NORTH

\begin{tabular}{|c|c|c|c|c|c|c|c|c|}
\hline NO. & $\begin{array}{l}\text { LENGTH } \\
\text { (FEET) }\end{array}$ & $\begin{array}{l}\text { NUMBER } \\
\text { OF B.O. }\end{array}$ & $\begin{array}{l}\text { QUALITY } \\
\text { FACTOR }\end{array}$ & $\begin{array}{l}\text { B.O. } \\
\text { AZIM. }\end{array}$ & $\begin{array}{l}\text { DEV. } \\
\text { AZIM. }\end{array}$ & $\begin{array}{l}\text { HOLE } \\
\text { DEV. }\end{array}$ & $\begin{array}{l}\text { INT. } \\
\text { TOP }\end{array}$ & $\begin{array}{l}\text { INT. } \\
\text { BOTTOM }\end{array}$ \\
\hline $\begin{array}{r}1 \\
2 \\
3 \\
4 \\
5 \\
6 \\
7 \\
8 \\
9 \\
10 \\
11 \\
12 \\
13 \\
14 \\
15 \\
16 \\
17 \\
18 \\
19 \\
20 \\
21 \\
22\end{array}$ & $\begin{array}{r}110.0 \\
90.0 \\
30.0 \\
6.0 \\
22.0 \\
18.0 \\
16.0 \\
78.0 \\
110.0 \\
92.0 \\
24.0 \\
616.0 \\
60.0 \\
270.0 \\
110.0 \\
154.0 \\
26.0 \\
20.0 \\
26.0 \\
16.0 \\
144.0 \\
260.0\end{array}$ & $\begin{array}{l}1.0 \\
1.0 \\
1.0 \\
1.0 \\
1.0 \\
1.0 \\
1.0 \\
1.0 \\
1.0 \\
1.0 \\
1.0 \\
1.0 \\
1.0 \\
1.0 \\
1.0 \\
1.0 \\
1.0 \\
1.0 \\
1.0 \\
1.0 \\
1.0 \\
1.0\end{array}$ & $\begin{array}{l}4 \\
3 \\
3 \\
4 \\
3 \\
3 \\
3 \\
5 \\
5 \\
5 \\
3 \\
5 \\
4 \\
3 \\
5 \\
5 \\
5 \\
5 \\
3 \\
3 \\
5 \\
5\end{array}$ & $\begin{array}{r}72.0 \\
62.0 \\
22.0 \\
-68.0 \\
67.0 \\
62.0 \\
62.0 \\
72.0 \\
62.0 \\
72.0 \\
52.0 \\
32.0 \\
-78.0 \\
62.0 \\
47.0 \\
52.0 \\
72.0 \\
87.0 \\
62.0 \\
47.0 \\
22.0 \\
22.0\end{array}$ & $\begin{array}{r}122.0 \\
102.0 \\
112.0 \\
82.0 \\
97.0 \\
102.0 \\
102.0 \\
242.0 \\
72.0 \\
247.0 \\
142.0 \\
212.0 \\
207.0 \\
212.0 \\
47.0 \\
62.0 \\
82.0 \\
167.0 \\
142.0 \\
112.0 \\
22.0 \\
212.0\end{array}$ & $\begin{array}{l}2.0 \\
1.0 \\
1.3 \\
1.0 \\
1.8 \\
1.8 \\
1.8 \\
1.0 \\
1.3 \\
2.1 \\
1.0 \\
1.8 \\
1.8 \\
1.8 \\
1.5 \\
1.5 \\
1.5 \\
0.5 \\
0.8 \\
0.8 \\
1.3 \\
1.0\end{array}$ & $\begin{array}{l}6840.0 \\
6550.0 \\
6520.0 \\
6346.0 \\
6252.0 \\
6176.0 \\
5920.0 \\
5542.0 \\
5130.0 \\
4648.0 \\
4186.0 \\
3334.0 \\
3270.0 \\
2990.0 \\
2830.0 \\
2676.0 \\
2650.0 \\
2240.0 \\
2160.0 \\
2134.0 \\
1910.0 \\
1580.0\end{array}$ & $\begin{array}{l}6950.0 \\
6640.0 \\
6550.0 \\
6352.0 \\
6274.0 \\
6184.0 \\
5936.0 \\
5620.0 \\
5240.0 \\
4740.0 \\
4210.0 \\
3950.0 \\
3330.0 \\
3260.0 \\
2940.0 \\
2830.0 \\
2676.0 \\
2260.0 \\
2186.0 \\
2150.0 \\
2054.0 \\
1840.0\end{array}$ \\
\hline
\end{tabular}

FOR DATA OF QUALITY 4 OR BETTER (INCLUDES 12 BREAKOUTS)
FOR DATA OF QUALITY 3 OR BETTER (INCLUDES 9 BREAKOUTS)

STATISTICS WEIGHTED BY BREAK OUT LENGTHS

SHmin $=\mathrm{N} 65.0 \mathrm{E}+-14.7$ DEGREES

SHmax $=\mathrm{N} 25.0 \mathrm{~W}+-14.7$ DEGREES

STANDARD ERROR $=1.1$ DEGREES
SHmin $=\mathrm{N} 59.5 \mathrm{E}+-9.4$ DEGREES SHmax $=\mathrm{N} 30.5 \mathrm{~W}+-9.4$ DEGREES STANDARD ERROR $=0.8$ DEGREES

\section{STATISTICS WEIGHTED BY NUMBER OF BREAK OUTS}

SHmin $=\mathrm{N} 64.1 \mathrm{E}+-20.5$ DEGREES

SHmax $=\mathrm{N} 25.9 \mathrm{~W}+-20.5$ DEGREES

STANDARD ERROR $=13.6$ DEGREES
SHmin $=\mathrm{N} 56.1 \mathrm{E}+-12.6$ DEGREES

SHmax $=\mathrm{N} 33.9 \mathrm{~W}+-12.6$ DEGREES

STANDARD ERROR $=10.3$ DEGREES

STATISTICS FOR HOLE AZIMUTH

HOLE ORIENTATION $=\mathrm{N} 63.6 \mathrm{E}+-38.1$ DEGREES

STANDARD ERROR $=2.9$ DEGREES

STATISTICS FOR RELATIVE BEARING

RELATIVE BEARING $=21.2+-40.1$ DEGREES

STANDARD ERROR $=3.0$ DEGREES 
LATITUDE $=47.1100$ LONGITUDE $=-123.6800$ DECLINATION $=20 . \dot{0}$ WASHINGTON, GRAYS HARBOR CO., AMOCO WEYERHAEUSER 1-29

HORIZONTAL AZIMUTHS ARE MEASURED CLOCKWISE WITH RESPECT TO TRUE NORTH

\begin{tabular}{rrrrrrrrr} 
LENGTH & \multicolumn{2}{c}{ NUMBER } & QUALITY & B.O. & DEV. & HOLE & INT. & INT. \\
NO. & (FEET) & OF B.O. & FACTOR & AZIM. & AZIM. & DEV. & TOP & BOTTOM \\
\hline 1 & 72.0 & 1.0 & 2 & -70.0 & 150.0 & 1.0 & 12202.0 & 12274.0 \\
2 & 43.0 & 1.0 & 1 & -70.0 & 140.0 & 1.0 & 12124.0 & 12167.0 \\
3 & 24.0 & 1.0 & 1 & -50.0 & 150.0 & 1.0 & 11970.0 & 11994.0 \\
4 & 16.0 & 1.0 & 1 & -60.0 & 140.0 & 1.0 & 11940.0 & 11956.0 \\
5 & 80.0 & 1.0 & 2 & -60.0 & 140.0 & 1.0 & 11860.0 & 11940.0 \\
6 & 48.0 & 1.0 & 1 & -65.0 & 160.0 & 1.0 & 11382.0 & 11430.0 \\
7 & 12.0 & 1.0 & 1 & -60.0 & 165.0 & 1.0 & 11328.0 & 11340.0 \\
8 & 16.0 & 1.0 & 1 & -50.0 & 160.0 & 1.0 & 11292.0 & 11308.0 \\
9 & 26.0 & 1.0 & 1 & -50.0 & 165.0 & 1.0 & 11260.0 & 11286.0 \\
10 & 20.0 & 1.0 & 1 & -55.0 & 170.0 & 1.0 & 11240.0 & 11260.0 \\
11 & 20.0 & 1.0 & 1 & -60.0 & 175.0 & 1.0 & 11220.0 & 11240.0 \\
12 & 50.0 & 1.0 & 2 & -60.0 & 175.0 & 1.0 & 11170.0 & 11220.0 \\
13 & 16.0 & 1.0 & 2 & -70.0 & 180.0 & 1.0 & 10964.0 & 10980.0 \\
14 & 16.0 & 1.0 & 3 & -20.0 & 180.0 & 1.0 & 10948.0 & 10964.0 \\
15 & 90.0 & 1.0 & 5 & 5.0 & 195.0 & 0.5 & 10590.0 & 10680.0 \\
16 & 25.0 & 1.0 & 3 & -20.0 & 190.0 & 0.5 & 10545.0 & 10570.0 \\
17 & 64.0 & 1.0 & 1 & -65.0 & 180.0 & 0.5 & 10370.0 & 10434.0 \\
18 & 20.0 & 1.0 & 2 & -55.0 & 180.0 & 0.5 & 10350.0 & 10370.0 \\
19 & 35.0 & 1.0 & 1 & -70.0 & 190.0 & 0.5 & 10300.0 & 10335.0 \\
20 & 10.0 & 1.0 & 2 & -60.0 & 205.0 & 0.5 & 10254.0 & 10264.0 \\
21 & 36.0 & 1.0 & 3 & 0.0 & 200.0 & 0.5 & 10174.0 & 10210.0 \\
22 & 54.0 & 1.0 & 3 & 20.0 & 185.0 & 0.5 & 10060.0 & 10154.0 \\
23 & 32.0 & 1.0 & 3 & 20.0 & 220.0 & 0.5 & 9990.0 & 10022.0 \\
24 & 40.0 & 1.0 & 1 & -70.0 & 230.0 & 1.0 & 5780.0 & 5820.0 \\
25 & 60.0 & 1.0 & 1 & -70.0 & 230.0 & 1.0 & 5680.0 & 5740.0
\end{tabular}

FOR DATA OF QUALITY 4 OR BETTER (INCLUDES 24 BREAKOUTS)
FOR DATA OF OUALITY 2 OR BETTER (INCLUDES 19 BREAKOUTS)

\section{STATISTICS WEIGHTED BY BREAK OUT LENGTHS}

SHmin $=N 58.1 \mathrm{~W}+-\quad 25.8$ DEGREES
SHmax $=\mathrm{N} 31.9 \mathrm{E}+-\quad 25.8$ DEGREES
STANDARD ERROR $=1.7$ DEGREES

SHmin $=\mathrm{N} 58.1 \mathrm{~W}+-25.8$ DEGREES

STANDARD ERROR $=1.7$ DEGREES

\author{
SHmin $=\mathrm{N} 63.5 \mathrm{~W}+-6.5$ DEGREES \\ SHmax $=\mathrm{N} 26.5 \mathrm{E}+-6.5$ DEGREES \\ STANDARD ERROR $=0.5$ DEGREES
}

STATISTICS WEIGHTED BY NUMBEK OF BREAK OUTS

SHmin $=N 55.7 \mathrm{~W}+-22.6$ DEGREES

SHmax $=\mathrm{N} 34.3 \mathrm{E}+-22.6$ DEGREES

STANDARD ERROR $=9.7$ DEGREES
SHmin $=\mathrm{N} 61.6 \mathrm{~W}+-7.0$ DEGREES

SHmax $=N 28.4 E+-7.0$ DEGREES

STANDARD ERROR $=3.5$ DEGREES

STATISTICS FOR HOLE AZIMUTH

HOLE ORIENTATION $=\mathrm{N} 5.4 \mathrm{~W}+-25.1$ DEGREES

STANDARD ERROR $=1.7$ DEGREES

STATISTICS FOR RELATIVE BEARING

RELATIVE BEARING $=36.4+-29.2$ DEGREES

STANDARD ERROR $=1.9$ DEGREES 
LATITUDE $=47.7920$ LONGITUDE $=-124.4250$ DECLINATION $=20.0$ JEFFERSON CO., WASHINGTON, PYRAMID PETROLEUM CORP.

HORIZONTAL AZIMUTHS ARE MEASURED CLOCKWISE WITH RESPECT TO TRUE NORTH

LENGTH NUMBER QUALITY B.O. DEV. HOLE INT. INT. NO. (FEET) OF B.O. FACTOR AZIM. AZIM. DEV. TOP BOTTOM

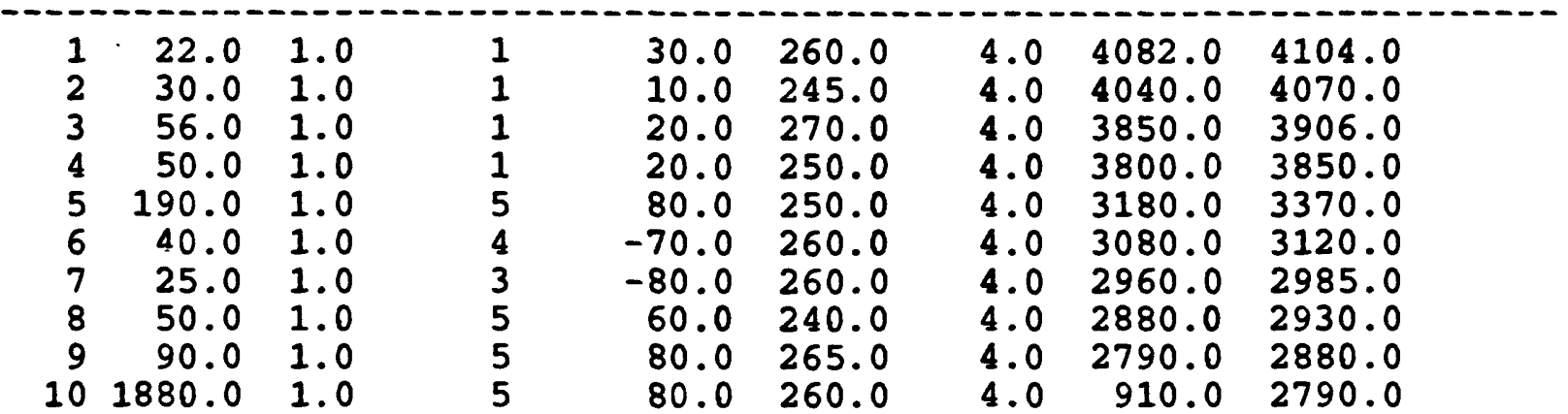

FOR DATA OF QUALITY 4 OR BETTER (INCLUDES 6 BREAKOUTS)
FOR DATA OF QUALITY 1 OR BETTER (INCLUDES 4 BREAKOUTS)

STATISTICS WEIGHTED BY BREAK OUT LENGTHS

SHmin $=\mathrm{N} 21.8 \mathrm{E}+-31.1$ DEGREES

SHmax $=\mathrm{N} 68.2 \mathrm{~W}+-31.1$ DEGREES

STANDARD ERROR $=4.1$ DEGREES

$$
\begin{aligned}
& \text { SHmin }=\mathrm{N} 19.5 \mathrm{E}+- \\
& \text { SHmax }=\mathrm{N} 70.5 \mathrm{~W}+-\quad 5.7 \text { DEGREES } \\
& \text { STANDARD ERROR }=\quad 0.9 \text { DEGREES }
\end{aligned}
$$

STATISTICS WEIGHTED BY NUMBER OF BREAK OUTS

SHmin $=\mathrm{N} 25.0 \mathrm{E}+-33.2$ DEGREES

SHmax $=\mathrm{N} 65.0 \mathrm{~W}+-\quad 3.2$ DEGREES

STANDARD ERROR $=38.2$ DEGREES
SHmin $=\mathrm{N} 20.0 \mathrm{E}+-\quad 7.0$ DEGREES
SHmax $=\mathrm{N} 70.0 \mathrm{~W}+-\quad 7.0$ DEGREES
STANDARD ERROR $=12.9$ DEGREES

STATISTICS FOR HOLE AZIMUTH

HOLE ORIENTATION $=\mathrm{N} 78.3 \mathrm{E}+-\quad 8.6$ DEGREES

STANDARD ERROR $=1.1$ DEGREES

STATISTICS FOR RELATIVE BEARING

RELATIVE BEARING $=53.7+31.5$ DEGREES

STANDARD ERROR $=4.1$ DEGREES 
LATITUDE $=48.1000$ LONGITUDE $=-123.8000$ DECLINATION $=22.0$

CLALLUM CO., WASHINGTON, TWIN RIVERS

HORIZONTAL AZIMUTHS ARE MEASURED CLOCKWISE WITH RESPECT TO TRUE NORTH

LENGTH NUMBER QUALITY B.O. DEV. HOLE INT. INT. NO. (FEET) OF B.O. FACTOR AZIM. AZIM. DEV. TOP BOTTOM

\begin{tabular}{|c|c|c|c|c|c|c|c|c|}
\hline $\begin{array}{r}1 \\
2 \\
3 \\
4 \\
5 \\
6 \\
7 \\
8 \\
9 \\
10 \\
11 \\
12 \\
13 \\
14 \\
15 \\
16 \\
17 \\
18 \\
19 \\
20\end{array}$ & $\begin{array}{r}870.0 \\
80.0 \\
30.0 \\
335.0 \\
160.0 \\
120.0 \\
255.0 \\
26.0 \\
20.0 \\
30.0 \\
30.0 \\
180.0 \\
55.0 \\
70.0 \\
100.0 \\
68.0 \\
32.0 \\
260.0 \\
110.0 \\
50.0\end{array}$ & $\begin{array}{l}1.0 \\
1.0 \\
1.0 \\
1.0 \\
1.0 \\
1.0 \\
1.0 \\
1.0 \\
1.0 \\
1.0 \\
1.0 \\
1.0 \\
1.0 \\
1.0 \\
1.0 \\
1.0 \\
1.0 \\
1.0 \\
1.0 \\
1.0\end{array}$ & $\begin{array}{l}5 \\
5 \\
5 \\
5 \\
5 \\
5 \\
5 \\
1 \\
2 \\
3 \\
3 \\
5 \\
2 \\
2 \\
5 \\
3 \\
3 \\
3 \\
3 \\
3\end{array}$ & $\begin{array}{r}27.0 \\
27.0 \\
47.0 \\
42.0 \\
42.0 \\
52.0 \\
37.0 \\
82.0 \\
57.0 \\
-38.0 \\
52.0 \\
32.0 \\
62.0 \\
62.0 \\
22.0 \\
-88.0 \\
-83.0 \\
-28.0 \\
-58.0 \\
12.0\end{array}$ & $\begin{array}{l}37.0 \\
37.0 \\
37.0 \\
37.0 \\
37.0 \\
37.0 \\
37.0 \\
37.0 \\
27.0 \\
27.0 \\
22.0 \\
22.0 \\
27.0 \\
27.0 \\
32.0 \\
32.0 \\
32.0 \\
47.0 \\
62.0 \\
57.0\end{array}$ & $\begin{array}{l}7.5 \\
7.5 \\
7.5 \\
7.5 \\
7.0 \\
6.0 \\
3.0 \\
2.5 \\
2.3 \\
1.8 \\
1.7 \\
1.5 \\
2.0 \\
2.0 \\
2.0 \\
2.0 \\
2.0 \\
1.5 \\
1.5 \\
1.8\end{array}$ & $\begin{array}{l}5730.0 \\
5580.0 \\
5550.0 \\
5210.0 \\
5030.0 \\
4850.0 \\
4090.0 \\
3994.0 \\
3750.0 \\
3590.0 \\
3520.0 \\
3220.0 \\
3165.0 \\
3080.0 \\
2980.0 \\
2832.0 \\
2800.0 \\
2440.0 \\
2310.0 \\
2190.0\end{array}$ & $\begin{array}{l}6600.0 \\
5660.0 \\
5580.0 \\
5545.0 \\
5190.0 \\
4970.0 \\
4345.0 \\
4020.0 \\
3770.0 \\
3620.0 \\
3550.0 \\
3400.0 \\
3220.0 \\
3150.0 \\
3080.0 \\
2900.0 \\
2832.0 \\
2700.0 \\
2420.0 \\
2240.0\end{array}$ \\
\hline
\end{tabular}

FOR DATA OF QUALITY 4 C? BETTER (INCLUDES 11 BREAKOUTS)
FOR DATA OF QUALITY 2 OR BETTER (INCLUDES 4 BREAKOUTS)

STATISTICS WEIGHTED BY BREAK OUT LENGTHS

SHmin $=\mathrm{N} 54.2 \mathrm{~W}+-\quad 35.1$ DEGREES
SHmax $=\mathrm{N} 35.8 \mathrm{E}+-\quad 35.1$ DEGREES
STANDARD ERROR $=\quad 2.5$ DEGREES

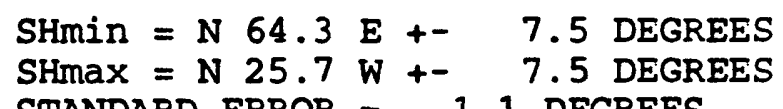

STANDARD ERROR $=1.1$ DEGREES

STATISTICS WEIGHTED BY NUMBER OF BREAK OUTS

SHmin $=\mathrm{N} 80.2 \mathrm{E}+-33.2$ DEGREES

SHmax $=\mathrm{N} 9.8 \mathrm{~W}+-33.2$ DEGREES

STANDARD ERROR $=23.4$ DEGREES
SHmin $=\mathrm{N} 65.6 \mathrm{E}+-$
SHmax $=\mathrm{N} 24.4 \mathrm{~W}+-$ STANDARD ERROR $=17.4 \mathrm{I} . \because$

STATISTICS FOR HOLE AZIMUTH

HOLE ORIENTATION $=\mathrm{N} 41.8 \mathrm{E}+-12.7$ DEGREES

STANDARD ERROR $=0.9$ DEGREES

STATISTICS FOR RELATIVE BEARING

RELATIVE BEARING $=71.8+-29.4$ DEGREES

STANDARD ERROR $=2.1$ DEGREES 
LATITUDE $=46.2080$ LONGITUDE $=-124.1350$ DECLINATION $=20.0$ GRAYS HARBOR CO., WASHINGTON

HORIZONTAL AZIMUTHS ARE MEASURED CLOCKWISE WITH RESPECT TO TRUE NORTH

LENGTH NUMBER QUALITY B.O. DEV. HOLE INT. INT. NO. (FEET) OF B.O. FACTOR AZIM. AZIM. DEV. TOP BOTTOM

\begin{tabular}{|c|c|c|c|c|c|c|c|c|}
\hline $\begin{array}{l}1 \\
2 \\
3 \\
4 \\
5 \\
6 \\
7\end{array}$ & $\begin{array}{l}78.0 \\
12.0 \\
16.0 \\
44.0 \\
66.0 \\
26.0 \\
65.0\end{array}$ & $\begin{array}{l}1.0 \\
1.0 \\
1.0 \\
1.0 \\
1.0 \\
1.0 \\
1.0\end{array}$ & $\begin{array}{l}3 \\
2 \\
2 \\
5 \\
3 \\
2 \\
2\end{array}$ & $\begin{array}{r}5.0 \\
70.0 \\
50.0 \\
25.0 \\
20.0 \\
90.0 \\
90.0\end{array}$ & $\begin{array}{l}245.0 \\
190.0 \\
190.0 \\
195.0 \\
180.0 \\
160.0 \\
150.0\end{array}$ & $\begin{array}{l}2.0 \\
2.0 \\
2.0 \\
2.0 \\
2.0 \\
2.0 \\
2.0\end{array}$ & $\begin{array}{l}3322.0 \\
2760.0 \\
2722.0 \\
2480.0 \\
2394.0 \\
1970.0 \\
1825.0\end{array}$ & $\begin{array}{l}3400.0 \\
2772.0 \\
2738.0 \\
2524.0 \\
2460.0 \\
1996.0 \\
1890.0\end{array}$ \\
\hline
\end{tabular}

FOR DATA OF QUALITY 4 OR BETTER (INCLUDES 6 BREAKOUTS)
FOR DATA OF QUALITY 2 OR BETTER (INCLUDES 4 BREAKOUTS)

STATISTICS WEIGHTED BY BREAK OUT LENGTHS

\begin{abstract}
SHmin $=N 40.0 \mathrm{~N}+-35.2$ DEGREES
SHMaX $=\mathrm{N} 50.0 \mathrm{~W}+-35.2$ DEGREES

STANDARD ERROR $=4.3$ DEGREES

SHmin $=\mathrm{N} 72.0 \mathrm{E}+-31.0$ DEGKEES

SHmax $=\mathrm{N} 18.0 \mathrm{~W}+-31.0$ DEGREES

STANDARD ERROR $=35.6$ DEGREES
\end{abstract}

$$
\begin{aligned}
& \text { SHmin }=N \quad 88.1 \mathrm{E}+- \\
& \text { SHmax }=N \quad 1.9 \mathrm{~W}+-\quad 5.9 \text { DEGREES }
\end{aligned}
$$$$
\text { STANDARD ERROR }=1.1 \text { DEGREES }
$$

STATISTICS WEIGHTED BY NUMBER OF BREAK OUTS

\begin{abstract}
SHmin $=\mathrm{N} 85.2 \mathrm{E}+-8.6$ DEGREES SHmaX $=\mathrm{N} 4.8 \mathrm{~W}+-8.6$ DEGREES STANDARD ERROR $=15.8$ DEGREES
\end{abstract}

STATISTICS FOR HOLE AZIMUTH

HOLE ORTENTATION $=\mathrm{N} 1.1 \mathrm{~W}+-32.4$ DEGREES

STANDARD ERROR $=3.9$ DEGREES

STATISTICS FOR RELATIVE BEARING

RELATIVE BEARING $=63.5+-31.6$ DEGREES

STANDARD ERROR $=3.8$ DEGREES 
LATITUDE $=47.1000$ LONGITUDE $=-124.3000$ DECLINATION $=20.0$

GRAYS HARBOR CO., WASHINGTON, SHELL

HORIZONTAL AZIMUTHS ARE MEASURED CLOCKWISE WITH RESPECT TO TRUE NORTH

LENGTH NUMBER QUALITY B.O. DEV. HOLE INT. INT. NO. (FEET) OF B.O FACTOR AZIM AZIM, DEV TOP BOTTOM

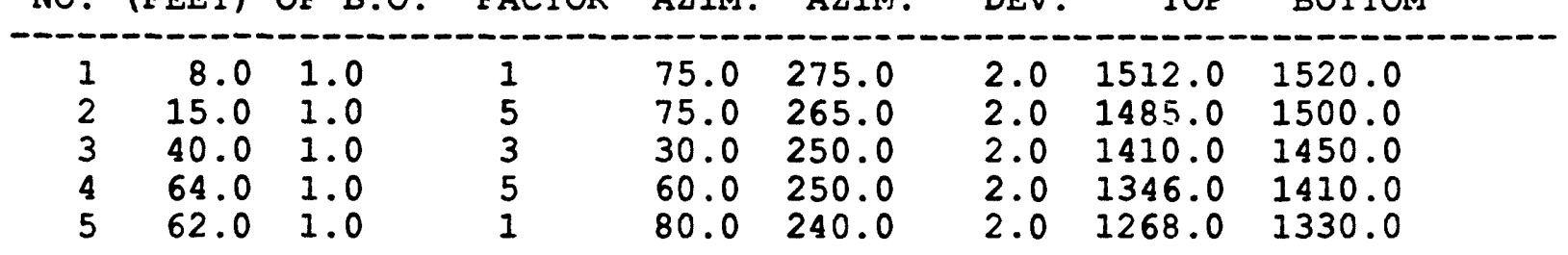

FOR DATA OF QUALITY I OR BETTER

(INCLUDES 2 BREAKOUTS)

STATISTICS WEIGHTED BY BREAK OUT LENGTHS
SHmin $=\mathrm{N} 77.2 \mathrm{E}+-$
DEGREES
SHmax $=\mathrm{N} 12.8 \mathrm{~W}+-$
DEGREES
STANDARD ERROR =
DEGREES

STATISTICS WEIGHTED BY NUMBER OF BREAK OUTS

$\begin{array}{llr}\text { SHmin }=N 77.5 \mathrm{E}+- & \text { DEGREES } \\ \text { SHmax }=\mathrm{N} 12.5 \mathrm{~W}+- & \text { DEGREES } \\ \text { STANDARD ERROR }= & \text { DEGREES }\end{array}$

STATISTICS FOR HOLE AZIMITH

HOLE ORIENTATION $=\mathrm{N} 65.9 \mathrm{E}+-\quad 9.1$ DEGREES

STANDARD ERROR $=1.7$ DEGREES

STATISTICS FOR RELATIVE BEARING

RELATIVE BEARING $=2.2+-27.1$ DEGREES

STANDARD ERROR $=5.1$ DEGREES 
LATITUDE $=47.1340$ LONGITUDE $=-124.1460$ DECLINATION $=20.0$

GRAYS HARBOR CO., WASHINGTON, SHELL

HORIZONTAL AZIMUTHS ARE MEASURED CLOCKWISE WITH RESPECT TO TRUE NORTH

LENGTH NUMBER QUALITY B.O. DEV. HOLE INT. INT. NO. (FEET) OF B.O. FACTOR AZIM. AZIM. DEV. TOP BOTTOM

\begin{tabular}{|c|c|c|c|c|c|c|c|c|}
\hline $\begin{array}{l}1 \\
2 \\
3\end{array}$ & $\begin{array}{l}20.0 \\
65.0 \\
50.0\end{array}$ & $\begin{array}{l}1.0 \\
1.0 \\
1.0\end{array}$ & $\begin{array}{l}3 \\
2 \\
2\end{array}$ & $\begin{array}{r}75.0 \\
-25.0 \\
-80.0\end{array}$ & $\begin{array}{r}320.0 \\
320.0 \\
35.0\end{array}$ & $\begin{array}{l}0.0 \\
0.0 \\
0.0\end{array}$ & $\begin{array}{r}1545.0 \\
1235.0 \\
540.0\end{array}$ & $\begin{array}{r}i 365.0 \\
1300.0 \\
590.0\end{array}$ \\
\hline
\end{tabular}

FOR DATA OF QUALITY 4 OR BETTER

(INCLUDES 3 BREAKOUTS)

STATISTICS WEIGHTED BY BREAK OUT LENGTHS

SHmin $=\mathrm{N} 55.8 \mathrm{~W}+-30.0$ DEGREES

SHmax $=\mathrm{N} 34.2 \mathrm{E}+-30.0$ DEGREES

STANDARD ERROR $=5.1$ DEGREES

STATISTICS WEIGHTED BY NUMBER OF BREAK OUTS

SHmin $=\mathrm{N} 76.2 \mathrm{~W}+-30.4$ DEGREES

SHmax $=\mathrm{N} 13.8 \mathrm{E}+-30.4$ DEGREES

STANDARD ERROR $=92.4$ DEGREES

STATISTICS FOR HOLE AZIMUTH

HOLE ORIENTATION $=\mathrm{N} 24.5 \mathrm{~W}+-32.4$ DEGREE,

STANDARD ERROR $=5.5$ DEGREES

STATISTICS FOR RELATIVE BEARING

RELATIVE BEARING $=39.2+30.9$ DEGREES

STANDARD ERROR $=5.2$ DEGREES 
LATITUDE $=46.9580$ LONGITUDE $=-123.6250$ DECLINATION $=20.0$ GRAYS HARBOR, WASHINGTON, EL PASO PRODUCTS, MONTESANO 1-X

HORIZONTAL AZIMUTHS ARE MEASURED CLOCKWISE WITH RESPECT TO TRUE NORTH

\begin{tabular}{|c|c|c|c|c|c|c|c|c|}
\hline No. & $\begin{array}{l}\text { LENGTH } \\
\text { (FEET) }\end{array}$ & $\begin{array}{l}\text { NUMBER } \\
\text { OF B.O. }\end{array}$ & $\begin{array}{r}\text { QUALITY } \\
\text { FACTOR }\end{array}$ & $\begin{array}{l}\text { B.O. } \\
\text { AZIM. }\end{array}$ & $\begin{array}{l}\text { DEV. } \\
\text { AZIM. }\end{array}$ & $\begin{array}{l}\text { HOLE } \\
\text { DEV. }\end{array}$ & $\begin{array}{l}\text { INT. } \\
\text { TOP }\end{array}$ & $\begin{array}{l}\text { INT. } \\
\text { BOTTOM }\end{array}$ \\
\hline $\begin{array}{l}1 \\
2 \\
3 \\
4 \\
5 \\
6 \\
7 \\
8 \\
9\end{array}$ & $\begin{array}{r}68.0 \\
230.0 \\
30.0 \\
60.0 \\
91.0 \\
38.0 \\
520.0 \\
260.0 \\
315.0\end{array}$ & $\begin{array}{l}1.0 \\
1.0 \\
1.0 \\
1.0 \\
1.0 \\
1.0 \\
1.0 \\
1.0 \\
1.0\end{array}$ & $\begin{array}{l}2 \\
5 \\
2 \\
3 \\
3 \\
2 \\
2 \\
5 \\
2\end{array}$ & $\begin{array}{r}90.0 \\
40.0 \\
70.0 \\
10.0 \\
-30.0 \\
75.0 \\
70.0 \\
75.0 \\
85.0\end{array}$ & $\begin{array}{r}225.0 \\
210.0 \\
200.0 \\
210.0 \\
200.0 \\
225.0 \\
220.0 \\
85.0 \\
240.0\end{array}$ & $\begin{array}{l}1.0 \\
1.2 \\
1.2 \\
1.5 \\
2.0 \\
4.0 \\
6.5 \\
6.0 \\
5.0\end{array}$ & $\begin{array}{r}5472.0 \\
5220.0 \\
5190.0 \\
5120.0 \\
5015.0 \\
2954.0 \\
2410.0 \\
2150.0 \\
700.0\end{array}$ & $\begin{array}{l}5540.0 \\
5450.0 \\
5220.0 \\
5180.0 \\
5106.0 \\
=992.0 \\
2930.0 \\
2410.0 \\
1015.0\end{array}$ \\
\hline
\end{tabular}

FOR DATA OF QUALITY 4 OR BETTER (INCLUDES 7 BREAKOUTS)
FOR DATA OF QUALITY 2 OR BETTER (INCLUDES 5 BREAKOUTS)

STATISTICS WEIGHTED BY BREAK OUT LENGTHS

\begin{abstract}
SHmin $=\mathrm{N} 76.6 \mathrm{E}+-21.1$ DEGREES
SHmax $=\mathrm{N} 13.4 \mathrm{~W}+-21.1$ DEGREES

STANDARD ERROR $=1.2$ DEGREES

SHmin $=\mathrm{N} 76.4 \mathrm{E}+-7.7$ DEGREES

SHmaX $=\mathrm{N} 13.6 \mathrm{~W}+-7.7$ DEGREES

STANDARD ERROR $=0.5$ DEGREES

STATISTICS WEIGHTED BY NUMBER OF BREAK OUTS

SHmin $=\mathrm{N} 78.0 \mathrm{E}+-\quad 8.1$ DEGREES SHmaX $=\mathrm{N} 12.0 \mathrm{~W}+-8.1$ DEJREES STANDARD ERROR $=11.2$ DEGREES

SHmin $=N 77.0 \mathrm{E}+-\quad 29.6$ DEGREES
SHmax $=\mathrm{N} 13.0 \mathrm{~W}+-29.6$ DEGREES
STANDARD ERROR $=29.6$ DEGREES
\end{abstract}

STATISTICS FOR HOLE AZIMUTH

HOLE ORIENTATION $=\mathrm{N} 43.4 \mathrm{E}+-12.1$ DEGREES

STANDARD ERROR $=0.7$ DEGREES

STATISTICS FOR RELATIVE BEARING

RELATIVE BEARING $=26.9+-19.6$ DEGREES

STANDARD ERROR $=1.1$ DEGREES 
PLUM CREEK 23-2

LATITUDE $=47.1000$ LONGITUDE $=-122.1000$ DECLINATION $=20.0$

PIERCE CO., WASHINGTON, MERIDIAN OIL CO.

HORIZONTAL AZIMUTHS ARE MEASURED CLOCKWISE WITH RESPECT TO TRUE NORTH

LENGTH NUMBER QUALITY B.O. DEV. HOLE INT. INT. NO. (FEET) OF B.O. FACTOR AZIM. AZIM. DEV. TOP BOTTOM

\begin{tabular}{|c|c|c|c|c|c|c|c|c|}
\hline $\begin{array}{l}1 \\
2 \\
3\end{array}$ & $\begin{array}{r}50.0 \\
130.0 \\
28.0 \\
340.0\end{array}$ & $\begin{array}{l}1.0 \\
1.0 \\
1.0 \\
1.0\end{array}$ & $\begin{array}{l}5 \\
5 \\
4 \\
3\end{array}$ & $\begin{array}{r}71.0 \\
70.0 \\
74.0 \\
-71.1\end{array}$ & $\begin{array}{l}257.0 \\
258.0 \\
284.0 \\
272.0\end{array}$ & $\begin{array}{r}13.0 \\
13.0 \\
7.0 \\
3.0\end{array}$ & $\begin{array}{r}3330.0 \\
3050.0 \\
1580.0 \\
660.0\end{array}$ & $\begin{array}{l}3380.0 \\
3180.0 \\
1608.0 \\
1000.0\end{array}$ \\
\hline
\end{tabular}

FOR DATA OF QUALITY 4 OR BETTER

(INCLUDES 2 BREAKOUTS) 